UNIVERSIDADE NOVE DE JULHO

PROGRAMA DE PÓS-GRADUAÇÃO STRICTO SENSU EM DIREITO

MESTRADO EM DIREITO

Zamis Maia Carneiro

O PAPEL DEMOCRÁTICO DO SUPREMO TRIBUNAL FEDERAL NAS PRÁTICAS DE ATIVISMO JUDICIAL

São Paulo

2020 
UNIVERSIDADE NOVE DE JULHO

PROGRAMA DE PÓS-GRADUAÇÃO STRICTO SENSU EM DIREITO

MESTRADO EM DIREITO

\section{O PAPEL DEMOCRÁTICO DO SUPREMO TRIBUNAL FEDERAL NAS PRÁTICAS DE ATIVISMO JUDICIAL}

Zamis Maia Carneiro

Dissertação apresentada ao Programa de Pós-Graduação Stricto Sensu Mestrado em Direito da Universidade Nove de Julho, para obtenção do título de Mestre em Direito.

Orientadora: $\operatorname{Prof}^{\mathrm{a}} \operatorname{Dr}^{\mathrm{a}}$ Luciana de Toledo Temer Lulia 
Carneiro, Zamis Maia.

O papel democrático do supremo tribunal federal nas práticas de ativismo judicial. / Zamis Maia Carneiro. 2020.

$109 \mathrm{f}$.

Dissertação (Mestrado) - Universidade Nove de Julho - UNINOVE, São Paulo, 2020.

Orientador (a): Prof ${ }^{\mathrm{a}}$. Dr ${ }^{\mathrm{a}}$. Luciana de Toledo Temer Lulia.

1. Direito Constitucional. 2. Democracia. 3. Supremo Tribunal Federal. 4. Separação dos Poderes. 5. Judicialização das Políticas Públicas.

I. Lulia, Luciana de Toledo Temer. II. Título. 
O PAPEL DEMOCRÁTICO DO SUPREMO TRIBUNAL FEDERAL NAS PRÁTICAS DE ATIVISMO JUDICIAL

UNIVERSIDADE NOVE DE JULHO

Data da aprovação _____

Banca examinadora

Prof. ${ }^{a}$ Dr. ${ }^{a}$ Luciana de Toledo Temer Lulia

Orientadora

UNINOVE

Prof. ${ }^{a}$ Dr. ${ }^{a}$ Samantha Ribeiro Meyer-Pflug Marques

UNINOVE

Prof. ${ }^{a}$ Dr. ${ }^{a}$ Márcia Cristina de Souza Alvim

$\mathrm{PUC} / \mathrm{SP}$

São Paulo 


\section{AGRADECIMENTOS}

Agradeço a Deus pelo fôlego de Vida. Aos meus pais, Cida e Heli, pela inspiração e exemplo de vida. Aos professores da Universidade Nove de Julho pelo esmero no dom do ensino,

Agradeço à Professora Dra. Luciana Temer pela oportunidade ímpar em ser seu orientando, pelos ensinamentos em sala de aula e, sobretudo, por compartilhar sua sabedoria e experiência, profunda gratidão.

Agradeço a todos os amigos do mestrado da UNINOVE que compartilharam seu companheirismo, suas experiências e conhecimentos comigo.

A todos os funcionários do programa de mestrado em direito da UNINOVE, especialmente Viviani e Camila pela competência e simpatia, e pela disposição em sempre ajudar e servir. 
"A democracia é o pior dos regimes políticos, mas não há nenhum sistema melhor que ela".

Winston Churchill 


\section{RESUMO}

O processo democrático tornou-se, nestes tempos, guia de todas as questões politicamente relevantes, sejam elas práticas ou teóricas. É possível notar que a democracia tem sofrido diversas modulações de acordo com as propostas de cada governo. Cada vez mais percebe-se que a noção de democracia que temos, hodiernamente, vem aperfeiçoando-se em relação às noções de democracia, desde sua origem. O nível de democracia de uma nação traz consequências diretas nos direitos humanos, bem como nos direitos fundamentais, na medida em que amplia ou diminui esses direitos. Numa sociedade em que se estabelece uma democracia representativa ou participativa, cada vez, mais clama-se aos seus representantes maior compromisso na promoção do desenvolvimento e da justiça social, muito embora a prática aponte para uma direção diversa. Aparentemente, a democracia participativa tem sido fragilizada, dado que não atende por completo aos anseios da sociedade, fazendo com que determinados grupos considerados minoritários não sejam, efetivamente, representados ou atendidos, nas suas necessidades. Diante da insuficiência de representatividade e efetividade na promoção e garantia dos direitos, os órgãos dos Poderes Legislativo e Executivo parecem inertes na concretização das políticas públicas. Nota-se que a edição de leis, pelos órgãos representativos, não consegue alcançar os vários seguimentos sociais. Muitas vezes, essas leis carecem de constitucionalidade. Com efeito, percebe-se que o Poder Público revela-se ineficaz, na concretização das políticas públicas. Por isso, é que se buscou a garantia dessas políticas e omissões legislativas, pela via judicial. A Constituição de 1988, promulgada no período em que se inicia o processo de redemocratização do Brasil, conferiu ao Supremo Tribunal Federal a atribuição, de modo mais abrangente, do controle de constitucionalidade das leis e atos normativos. E, este instrumento tem sido utilizado para efetivação, obtenção e cumprimento dos direitos e garantias fundamentais. Nessa perspectiva, este trabalho busca analisar o caráter democrático do Supremo Tribunal Federal nas práticas de ativismo judicial.

PALAVRAS-CHAVE: Direito Constitucional. Democracia. Supremo Tribunal Federal. Separação dos Poderes. Judicialização das Políticas Públicas. Ativismo Judicial. Direitos Fundamentais. 


\begin{abstract}
The democratic process has now become a guide for all politically relevant issues, be they practical or theoretical. It is possible to note that democracy has undergone several modulations according to the proposals of each government. It is increasingly perceived that the notion of democracy that we have today has been improving in relation to the notions of democracy, since its origin. A nation's level of democracy has direct consequences for human rights, as well as fundamental rights, to the extent that it extends or diminishes those rights. In a society in which a representative or participatory democracy is established, its representatives are increasingly calling for a greater commitment to promoting development and social justice, even though the practice points in a different direction. Apparently, participatory democracy has been weakened, to the extent that it does not fully meet the needs of society, causing certain groups considered minority to not be effectively represented or attended to in their needs. In view of the insufficiency of representativeness and effectiveness in promoting and guaranteeing rights, the bodies of the Legislative and Executive Powers seem inert in the implementation of public policies. It should be noted that the enactment of laws, by the representative bodies, fails to reach the various social segments. These laws often lack constitutionality. Indeed, it is clear that the Public Power proves to be ineffective in the implementation of public policies. For this reason, it was sought to guarantee these policies and legislative omissions, through the judicial system. The 1988 Constitution, promulgated in the period when the process of redemocratization of Brazil begins, gave the Supreme Federal Court the attribution, in a more comprehensive way, of the constitutionality control of laws and normative acts. And, this instrument has been used to implement, obtain and fulfill fundamental rights and guarantees. In this perspective, this paper seeks to analyze the democratic character of the Supreme Federal Court in the practices of judicial activism.
\end{abstract}

KEYWORDS: Constitutional Law. Democracy. Federal Court of Justice. Separation of Powers. Judicialization of Public Policies. Judicial Activism. Fundamental rights. 


\section{Sumário}

INTRODUÇÃ

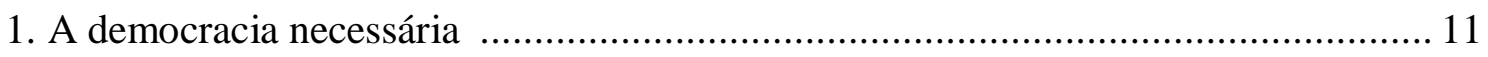

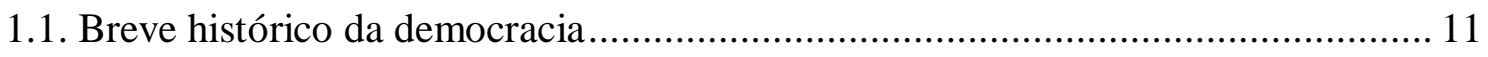

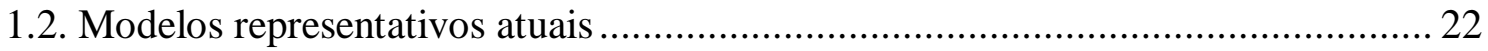

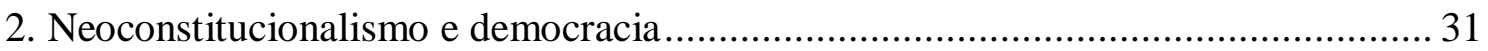

2.1. Os controles difuso e abstrato de constitucionalidade de normas........................... 37

2.2. Considerações sobre as origens do controle de constitucionalidade no Brasil........ 41

2.3. Perspectivas do ativismo judicial como práticas comuns do Supremo Tribunal

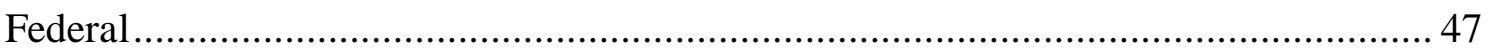

3. Separação dos poderes e o Supremo Tribunal Federal ............................................ 59

3.1. A separação de poderes de Montesquieu............................................................... 61

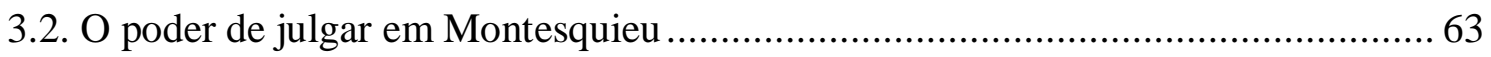

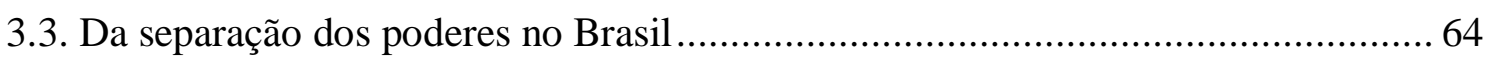

3.4. O ativismo judicial do STF como fator de desequilíbrio entre os poderes?............ 71

4. O Supremo Tribunal Federal e o Ativismo Judicial ................................................. 79

4.1. O caráter democrático do Supremo Tribunal Federal .......................................... 85

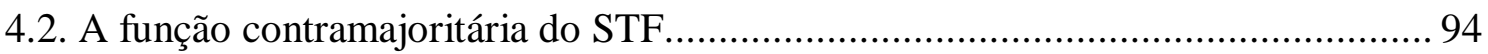

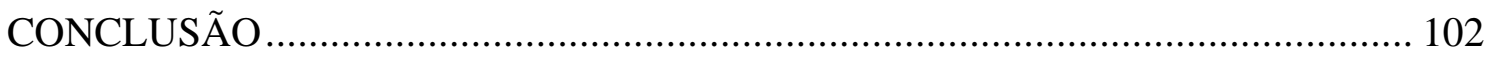

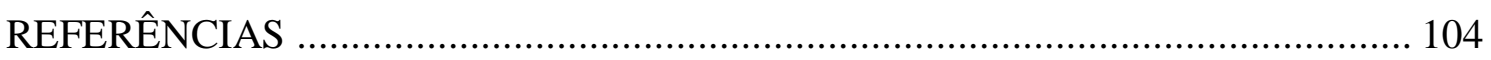




\section{INTRODUÇÃO}

A democracia tem sido construída, ao longo da história, como um modo de possibilitar maior participação dos cidadãos nas decisões do Estado. Ainda, luta-se para sua consolidação, em substituição aos regimes autoritários, promovendo a defesa dos direitos humanos e tendo como objetivo a construção de uma sociedade pautada na liberdade, igualdade e justiça.

Entretanto, as democracias sofrem da crise de representatividade, que acaba por gerar fragilidade na efetivação, concretização, promoção e garantia dos direitos fundamentais. No Brasil, os poderes Legislativo e Executivo sofrem de crise institucional, e se revelam ineficientes na concretização das políticas públicas e na elaboração das leis.

Ocorre que, muitas leis, ao serem editadas, passam pelo controle de constitucionalidade, pois mostram-se omissas ou violadoras das disposições constitucionais, ou até mesmo possuem vício de formalidade. Os mecanismos de controle de constitucionalidade foram ampliados no Brasil, possibilitando que o Supremo Tribunal Federal aja em defesa da Constituição, garantindo equilíbrio institucional. A valer, o controle de constitucionalidade tem sido utilizado como ferramenta para a promoção das práticas de ativismo judicial.

O ativismo judicial consiste na atuação do Supremo Tribunal Federal para suprir omissões legislativas ou para dar uma interpretação mais abrangente a lei ou ato normativo, tornando-a compatível com as disposições da Constituição Federal. Essa interpretação mais extensiva da Constituição Federal baseia-se no advento do neoconstitucionalismo, que confere aos princípios constitucionais força normativa. Além disso, são utilizados para garantir os direitos fundamentais, que, por vezes, não estão abarcados pela legislação ordinária. O neoconstitucionalismo tem sido severamente criticado, dado que utiliza-se de aspectos subjetivos, nos julgamentos dos casos concretos, acarretando na usurpação das funções exclusivas dos outros poderes da República. Essa atuação do Supremo Tribunal Federal, por vezes entendida como exagerada, justifica-se quando o conjunto de deficiências institucionais força a sociedade a buscar garantia dos direitos fundamentais pela via judicial.

Vale destacar que o Brasil adotou o princípio da separação dos poderes, cujo propósito é o de estabelecer equilíbrio institucional, a fim de que cada esfera de poder encontre limites nas suas atribuições, respeitando a margem de atuação dos demais. 
Porém, o cenário contemporâneo revela a crise institucional que se instalou no Brasil e, consequentemente, fez com que o Poder Judiciário adquirisse o protagonismo de resolver quase que todas as questões da nação, sejam elas de ordem política, social ou econômica.

Em razão da crise institucional, a judicialização das políticas públicas e as práticas de ativismo judicial consistem numa medida temporária e paliativa, para a promoção e concretização dos direitos fundamentais.

Nesse sentido, o Supremo Tribunal Federal incorpora o caráter democrático, tendo em vista que, os cidadãos e setores da sociedade, acionam-no para obterem o pronunciamento que o Legislativo não fornece e a concretização das políticas públicas que o Executivo não concede.

Conforme estabelecido na Constituição de 1988, a elaboração de leis é de competência exclusiva do Poder Legislativo, ele foi revestido de legitimidade democrática para tal finalidade. Já o cumprimento, execução das leis e concretização das políticas públicas é de atribuição do Poder Executivo. O Legislativo e o Executivo possuem caráter representativo, e, em tese, expressam a vontade da maioria. O Supremo Tribunal Federal, em regra, não é um órgão de representação, e sua atribuição exclusiva é a de ser guardião da Constituição. Por haver fragilidade institucional nos órgãos de representação, é que o Supremo Tribunal Federal age como um representante democrático daqueles que buscam sua tutela, e, além disso, exerce uma função contramajoritária, que se vale da invalidação de leis e atos normativos elaborados pelos poderes Executivo e Legislativo, por juízes que não foram eleitos, a fim de assegurar o cumprimento das disposições constitucionais.

Outro aspecto fundamental na atuação do Supremo Tribunal Federal se dá na mutação da sua jurisprudência, tendo em vista que, durante algum tempo, aplicava a "teoria da reserva do economicamente possível", nas questões que envolviam os direitos sociais, passando, agora, a adotar a "teoria do mínimo existencial", que se alicerça no fato de que o Estado não pode omitir-se no dever de oferecer condições mínimas de qualidade de vida, destacando entre elas a saúde, a moradia, a alimentação e a educação, a fim de que o cidadão se desenvolva em amplos sentidos.

Sobre este trabalho, o método de abordagem adotado no desenvolvimento da pesquisa é o hipotético-dedutivo, em uma perspectiva crítica, comparativa e histórica, de acordo com a linha de pesquisa 1 do programa denominado: Justiça e o Paradigma da Eficiência, tendo como escopo a área de concentração Justiça, Empresa e 
Sustentabilidade, haja vista o momento histórico contemporâneo que envolve diretamente as relações culturais, econômicas, ambientais e sociais. 


\section{A DEMOCRACIA NECESSÁRIA}

Há uma frase de Winston Churchill que diz "a democracia é o pior dos regimes políticos, mas não há nenhum sistema melhor que ela" ${ }^{1}$. Parece desconcertante quando ele diz que a democracia é o pior dos regimes, mas quando colocada ao lado e comparada aos outros regimes existentes, faz todo sentido.

Com a queda dos regimes autoritários, na maioria dos países, o processo democrático expandiu-se por todo o mundo, como um modelo de governo que traz esperança aos indivíduos, tornando possível a participação de quase toda a sociedade, nas decisões do Estado, seja por meio de representantes eleitos, ou diretamente.

\subsection{Breve histórico da democracia}

A concepção de Estado democrático encontrou inspiração nos gregos, cuja ideia era a de que pudesse haver um "governo do povo". Porém, a concepção de povo para os gregos era diversa da que compreende-se atualmente. Povo era um indivíduo ou uma partícula da sociedade que tinha poderes de deliberação política ou judicial, capazes de interferir nos interesses de todos.

É importante destacar que, no decurso da história, a concepção de Estado passou por fortes transformações, bem como a democracia passa por modulações na sua implementação, isto de acordo com os agentes que a controlam ao tornarem-se integrantes do governo. Dalmo de Abreu Dallari mostra que:

\footnotetext{
Um dos principais motivos de crise do Estado contemporâneo é que o homem do século XX está preso a concepções do século XVIII, quanto à organização e aos objetivos de um Estado Democrático. A necessidade de eliminar o absolutismo dos monarcas, que sufocava a liberdade dos indivíduos, mantinha em situação de privilégio uma nobreza ociosa e negava segurança e estímulo às atividades econômicas, levou a uma concepção individualista da sociedade e do Estado ${ }^{2}$.
}

Estudiosos sustentam que a concepção moderna de democracia surge no século XVIII, diante do cenário obscuro da tirania e do absolutismo. Movimentos da burguesia

\footnotetext{
${ }^{1}$ Disponível em https://www.pensador.com/frase/MTM5MTc4Mw/ acesso em 30.04.19

2 DALLARI. Dalmo de Abreu. Elementos de Teoria Geral do Estado/ Dalmo de Abreu Dallari. - 24.ed. - São Paulo: Saraiva, 2003. p. 300.
} 
levantaram-se, nesse período, para impor uma revolução, cujo propósito era limitar os poderes do Estado. A preocupação, nesse período, girava em torno da garantia das liberdades individuais, que só seria possível usufruir, se o Estado não agisse de modo arbitrário. Sobre a construção do Estado democrático, Dalmo de Abreu Dallari ensina:

O Estado Democrático nasceu das lutas contra o absolutismo, sobretudo, através da afirmação dos direitos naturais da pessoa humana. Daí a grande influencia dos jusnaturalistas, como LOCKE E ROUSSEAU, embora estes não tivessem chegado a propor a adoção de governos democráticos, tendo mesmo ROUSSEAU externado seu descrédito neles. De fato, após admitir que o governo democrático pudesse convir aos pequenos Estados, mas apenas estes, diz “que um povo que governar sempre bem não necessitará de ser governado", acrescentando que jamais existiu verdadeira democracia, nem existirá nunca ${ }^{3}$.

Apesar de Rousseau ser pessimista, em relação a um governo do povo, pela incapacidade que ele teria de se autogovernar e por ser um modelo quase que divino, a noção moderna que se tem de Estado Democrático deve-se a ele.

A condução ao Estado Democrático deu-se também, por meio de três movimentos político-sociais de grande expressão que serviram de fundamento para a implementação desse ideal. Chamados de Revoluções Liberais, esses movimentos constituem-se na Revolução Inglesa, cuja expressão memorável está contida no Bill of Rights de 1698, na Revolução Americana de 1776, sendo seus objetivos traçados na Declaração de Independência das treze colônias e, por fim, a Revolução Francesa, tendo seus princípios alicerçados na Declaração dos Direitos do Homem e do Cidadão, em 1789. Estes movimentos políticos é que trouxeram impulso inicial para a construção da concepção de Estado Democrático ${ }^{4}$. De forma sucinta, Dalmo de Abreu Dallari traça os princípios orientadores da constituição do Estado Democrático:

A supremacia da vontade popular, que colocou o problema da participação popular no governo, suscitando acesas controvérsias e dando margem às mais variadas experiências, tanto no tocante a representatividade, quanto à extensão do direito de sufrágio e aos sistemas eleitorais e partidários. A preservação da liberdade, entendida sobretudo como o poder de fazer tudo o que não incomodasse o próximo e como o poder de dispor de sua pessoa e de

\footnotetext{
${ }^{3}$ Op.cit. p. 147

${ }^{4}$ Op.cit. p. 147
} 
seus bens, sem qualquer interferência do Estado. A igualdade de direitos, entendida como a proibição de distinções no gozo de direitos, sobretudo por motivos econômicos ou de discriminação entre classes sociais ${ }^{5}$.

O Estado Democrático foi construído sob a premissa da liberdade e da igualdade, e a partir do ideário coletivo, da consciência única de que o povo é soberano, e é através dele que as vontades, comuns a todos, sejam exercidas da melhor maneira, por meio da atuação do governo que agora passa a ser formado e integrado pela soberania popular.

Nos países democráticos, estes princípios foram incorporados à suas políticas internas, proporcionando certa margem de segurança para seus projetos nacionais. Dependendo do nível democrático de uma nação, é possível conceder menos ou mais liberdades, menos ou mais participação popular, menos ou mais igualdade de direitos.

Neste sentido, Norberto Bobbio, ao se referir ao uso prescritivo do conceito de democracia, elucida:

\footnotetext{
Com respeito ao significado prescritivo, a democracia pode ser considerada, como de resto todas as demais formas de governo, como sinal positivo ou negativo, isto é, como uma forma boa, e, portanto, a ser louvada e recomendada, ou como uma forma má, e, portanto, a ser reprovada e desaconselhada. Toda história do pensamento político está atravessada pela disputa em torno da melhor forma de governo: no interior dessa disputa, um dos temas recorrentes é a argumentação pró e contra a democracia ${ }^{6}$.
}

No campo conceitual, a democracia, basicamente, é a forma de governo pela qual o poder político é exercido pelo povo. Ela é um dos modos pelos quais o poder político pode ser exercido, tornando-se diferente da monarquia, que representa o poder exercido por um, bem como da aristocracia que é identificada como o poder que é exercido por poucos, isto é, grupos específicos de pessoas.

A concepção de democracia sofre variantes, ou seja, constitui-se um modelo bom ou ruim de poder político. Alguns traços históricos refletem que essa forma de governo não tinha unanimidade quanto à sua implementação, se seria um projeto bem

\footnotetext{
${ }^{5}$ Op.cit. p. 151

${ }^{6}$ BOBBIO, Norberto. Estado, governo, sociedade; para uma teoria geral da política. Rio de Janeiro: Paz e Terra, 1987. p. 139.
} 
ou mal sucedido. Neste sentido, em relação às disputas que ocorreram ao longo da história acerca dos benefícios e malefícios da democracia, Norberto Bobbio relata:

(...) a disputa em torno da democracia não se refere se ela é melhor ou pior do que as outras, ou seja, qual é a sua colocação num ordenamento axiológico (isto é, segundo o valor) das constituições. Numa tipologia que não se distingue as formas puras das corruptas, as teses possíveis são três: se a democracia é a melhor, se é a pior ou se está no meio entre a melhor e a pior. As teses historicamente mais frequentes e relevantes são as duas primeiras, já que o confronto ocorre habitualmente entre as duas formas extremas que são precisamente a monarquia e a democracia ${ }^{7}$.

A compreensão sobre a democracia ser boa ou má gira em torno dos silogismos, se ela é a pior ou melhor das formas boas, ou se ela é a melhor ou pior das formas más de exercício do poder político. Certo é que, até mesmo os teóricos da ciência política clássica/moderna, são céticos em relação a democracia ser um bom modelo. Boa parte deles consideram que não, e entendem que a monarquia seria o melhor regime governamental. Norberto Bobbio disserta:

\footnotetext{
Assim, Bodin, Hobbes, Locke, Vico, Montesquieu, Kant, Hegel. Enquanto alguns destes autores, que consideram as diversas formas de governo em seu desenvolvimento histórico (como Vico, Montesquieu, Hegel), exaltam a monarquia como forma de governo mais adaptada à época a eles contemporânea, outros (como Hobbes e Bodin) fazem uma comparação em abstrato, na qual são acolhidos todos os argumentos tradicionais contra o governo do povo, todos os motivos antigos e modernos do antidemocratismo (os quais se transferem sem variações sensíveis à publicística de direita dos nossos dias) ${ }^{8}$.
}

Os momentos históricos demonstram que os ideais e as concepções foram se aperfeiçoando com o passar do tempo. A evolução da sociedade contribuiu para a evolução do Estado e consequentemente para a evolução das formas de governo. Partindo do princípio de que as sociedades primitivas tinham uma organização tribal, onde havia figuras representativas como o xamã ou sacerdotes, responsável pela interpretação dos fenômenos da natureza, tratando-os como sinais ou métodos de

\footnotetext{
${ }^{7}$ Op.cit. p. 142

${ }^{8}$ Op.cit. p.143
} 
comunicação divinos, bem como as sociedades antigas que tinham a Teocracia, o governo divino, como forma de Estado, acabaram por desaguar na monarquia que compreendia ter adquirido status de realeza por escolha divina. Com os exageros da monarquia absolutista, novas concepções foram elaboradas para a "melhoria" do sistema. A monarquia agora poderia ser controlada por um parlamento, composto de representantes sociais, e que de certo modo, controlava algumas ações dos interesses da coroa. Com o enfraquecimento da monarquia, o Estado agora não seria mais o sujeito escolhido por força divina, mas sim um ente despersonalizado, dotado de atribuições e características comum a todos. O Estado agora não seria composto por um ou por poucos, mas por todos.

Este processo de enfraquecimento da monarquia ganhou margem com a teoria da divisão de poderes de Montesquieu, que entendia que o monarca não deveria acumular para si "todos os poderes" inerentes a um Estado, isto é, o poder de legislar, o poder de julgar e o poder de executar. Inspirado no modelo Inglês de governo, onde havia a figura do parlamento, Montesquieu encontrou razões suficientes para construir uma teoria que tendia a diluir os poderes da monarquia, e isso de fato contribuiu para que esta forma de governo fosse, aos poucos, transformada, em um novo conceito de Estado, a república.

Montesquieu era cético em relação à democracia, pois cria que a sociedade composta pela população comum, não tinha condições de escolher adequadamente seus representantes, dessarte, como Rousseau, que afirmava que a democracia jamais existiria, pois que era necessário o preenchimento de alguns requisitos, dentre eles, um Estado muito pequeno, onde houvesse a possibilidade de todos os cidadãos se reunirem, a fim de deliberar os dilemas sociais, e que esses cidadãos pudessem se conhecer mutuamente.

Nem o ceticismo de Montesquieu e tampouco o pessimismo de Rousseau, foram capazes de imaginar que um modelo republicano, e posteriormente democrático, estava surgindo num grande território e ainda por cima, que buscou alicerçar seus fundamentos com base na teoria elaborada por eles. Os Estados Unidos da América surgiram com base em um pensamento republicano, como também democrático. Sob este prisma, Norberto Bobbio assevera: 
Estado no novo mundo como forma autêntica da democracia dos modernos contraposta à democracia dos antigos. Na advertência anteposta à edição de 1848, Tocqueville escreve que a América havia resolvido o problema da liberdade democrática que a Europa apenas começava a se colocar naquele momento: "Há sessenta anos o princípio da soberania do povo, que tínhamos introduzido ontem em nosso país, reina soberano na América, posto em prática do modo mais direto, mais ilimitado, mais absoluto" ${ }^{9}$.

Os contextos em que o pensamento democrático foram elaborados são as inspirações, que as sociedades pós-modernas baseiam-se, para estruturar esse modelo de governo e de exercício de poder.

Em contrapartida, observa-se atualmente que, em determinados momentos, modelos ou concepções consideradas mortas voltam à tona, diante das reações populares de inconformismo com o governo e seu método de gestão.

É possível afirmar que, no século XXI, há os que defendam um modelo monárquico, em países onde este regime é inexistente, há aqueles que defendem regimes autoritários, em países que superaram essa fase, e outros que clamam pelo fim do Estado e da democracia, em locais onde o Estado é eficiente e a participação popular é mais intensa.

Sob este prisma, é que a democracia nasce e encontra variações diversas, quanto ao seu modo de exercício. A democracia pode ser direta, semidireta ou representativa. E, em relação ao desenvolvimento da democracia, é possível afirmar que ela pode ser política ou social, bem como ter caráter substancial ou formal.

Na organização dos estados democráticos, a opção por um modo de exercício de poder político, por parte do povo, é de fundamental importância. Num Estado em que se adota uma democracia direta, que possivelmente seria a forma mais ideal de exercício do poder político, os cidadãos participam diretamente do processo de decisões, não transferindo seu poder de decisão. As decisões são tomadas em conjunto, formando-se assembleias para deliberação dos assuntos gerais. Havendo necessidade de estabelecerse um representante, seu mandato é vinculado aos eleitores e pode ser revogado, a qualquer momento.

Sobre a democracia direta, Norberto Bobbio ensina:

\footnotetext{
${ }^{9}$ Op.cit. p. 151
} 
É evidente que, se por democracia direta se entende literalmente a participação de todos os cidadãos em todas as decisões a eles pertinentes, a proposta é insensata. Que todos os decidam sobre tudo em sociedade sempre mais complexas como são as modernas sociedades industriais é algo materialmente impossível. E também não é desejável humanamente, isto é, do ponto de vista do desenvolvimento ético e intelectual da humanidade ${ }^{10}$.

Esse modelo de democracia pode representar uma espécie de totalitarismo inverso, ao considerar que aqueles que tem o poder de deliberação são absolutos em suas decisões, o que geraria, de certo modo, uma dificuldade em se governar, já que o poder está concentrado na sua amplitude, nas mãos dos cidadãos. Estes podem, a qualquer momento, retroceder em suas decisões, o que aparentemente acarretaria certa instabilidade.

Este modelo de democracia direta é quase inexistente atualmente, somente em alguns locais da Suíça é que este poder de deliberação é exercido. É nos chamados cantões da Suíça que a democracia direta é exercida, por meio do órgão Landsgemeinde. Sobre ela, Dalmo de Abreu Dallari ensina:

Durante séculos a Landsgemeinde foi o órgão supremo em todos os pequenos Cantões da Suíça central e oriental, começando com a sua abolição no século XIX. Trata-se de uma assembleia, aberta a todos os cidadãos do Cantão que tenham o direito de votar, impondo-se a estes o comparecimento como um dever. A Landsgemeinde reúne-se ordinariamente uma vez por ano, num domingo da primavera, podendo, entretanto haver convocações extraordinárias ${ }^{11}$.

Para a implementação desse modelo em um país, exige-se que instrumentos de consulta e deliberação popular sejam utilizados, como assembleias, plebiscitos e referendos, organizações de mobilização nacional.

Destaca-se que atualmente há uma releitura da democracia direta, ou pode ser descrita como um aperfeiçoamento desse modelo, denominado democracia líquida, sendo um método híbrido, isto é, uniria as diretrizes da democracia direta com a democracia representativa, a fim de fundir suas melhores características, para que a

\footnotetext{
${ }^{10}$ BOBBIO, Norberto. O futuro da democracia. São Paulo: Paz e Terra, 2000. p. 54

${ }^{11}$ Op. cit. p.152
} 
participação do cidadão nas decisões políticas tenham maior amplitude. A descrição é apontada no site do Partido Pirata brasileiro:

A ideia básica é: um eleitor pode transferir seu voto a um delegado (tecnicamente uma procuração transitória). $\mathrm{O}$ voto pode então ser transferido adiante, construindo assim uma rede de confiança. Todas as delegações podem ser efetuadas, alteradas e revogadas por tópico. Eu voto por mim mesmo em questões de meio ambiente, Anne me representa em política externa e Mike me representa em todas as outras áreas, mas eu posso mudar de ideia a qualquer momento.

Qualquer um pode escolher seu próprio caminho, desde a democracia pura até a democracia representativa. Basicamente, cada um participa naquilo que o interessa, mas em todas as outras áreas repassa seu voto a alguém que age em seu interesse. Claro que eventualmente alguém pode fazer uma má escolha, mas poderá mudar de ideia a qualquer momento ${ }^{12}$.

Para que a implementação da democracia líquida torne-se mais eficaz, um sistema de tecnologia da informação será utilizado como ferramenta hábil para adquirir maior alcance. O projeto tem o nome de LiquidFeedback. Acerca dessa ferramenta, o Partido Pirata brasileiro descreve:

\begin{abstract}
O LiquidFeedback é um sistema online para discussão e votação de propostas no contexto de um partido (ou organização), e compreende o processo que vai desde a introdução do primeiro rascunho de uma proposta até a decisão final. Discutir um tema antes da votação aumenta a consciência dos prós e dos contras, oportunidades e riscos, e permite que as pessoas considerem e sugiram alternativas. Ele combina conceitos de um processo de discussão não moderado e auto-organizado (feedback construtivo e quantificado) e democracia líquida (ou delegada ou por procuração) ${ }^{13}$.
\end{abstract}

A intenção de se ampliar o processo de democratização política é válida e deve ser enaltecida, frente a diversidade de conceitos e novas teorias que surgem ao longo da história. Os modelos clássicos vão sofrendo releituras, e, desse modo, a democracia direta pode adquirir novas roupagens possíveis para possibilitar maior participação

\footnotetext{
12 PARTIDO PIRATA DO BRASIL. O que é democracia direta. 23 jun. 2013. Disponível em http://partidopirata.org/o-que-e-democracia-direta/ Acesso em 22.08.19

${ }^{13}$ Ibidem.
} 
política da população. A democracia líquida é um projeto de construção de democratização social e política.

Pode-se dizer que, na democracia semidireta, há uma mescla de institutos da democracia direta e da democracia representativa. Neste modelo, o povo não tem amplitude nas decisões políticas, ficando de certo modo, barrados por alguma espécie de representação.

A democracia semidireta possibilita, em certa medida, um equilíbrio entre o exercício direto da soberania popular e a representação política. Faz-se oportuno explicitar que, no Brasil, o modelo adotado, foi o da democracia semidireta, cuja disposição constitucional deixa claro, "Todo o poder emana do povo, que o exerce por meio de representantes eleitos ou diretamente, nos termos desta Constituição" ${ }^{14}$.

A disposição constitucional deixa notória a presença da democracia semidireta no Estado Democrático de Direito brasileiro, sendo o poder exercido diretamente pela população, bem como através de representantes eleitos.

Assevera-se que, no Brasil, a democracia semidireta pode ser exercida, tendo como pressuposto a soberania popular, por meio de ferramentas como o plebiscito, a iniciativa popular e o referendo. Além disso, há outras formas de participação direta que estão esparsas na Constituição Federal de 1988, conforme observa Luís Gustavo Henrique Augusto:

Em todo o texto constitucional encontram-se dispositivos que garantem o exercício direto da soberania popular, como se verifica, por exemplo, nos artigos: $5^{\circ}$, LXXIII, que assegura o direito do cidadão ajuizar Ação Popular para anular ato lesivo ao patrimônio público ou de entidade que o Estado participe; 10, que prescreve a participação de trabalhadores e empregadores nos colegiados dos órgãos públicos em que seus interesses profissionais ou previdenciários estejam sendo discutidos ou deliberados; 14, que alberga o sufrágio, o plebiscito, o referendo e a iniciativa popular; 29,XII, determinando a cooperação das associações representativas no planejamento municipal; e37, $\S 3^{\circ}$, que garante a participação do usuário na administração pública. Considerando-se somente essas citações, já é possível verificar que a Constituição não somente assegurou a participação política da sociedade, como a garantiu no âmbito dos três poderes ${ }^{15}$.

14 BRASIL. Constituição Federal de 1988. Artigo $1^{\circ}$, parágrafo único. Disponível em: http://www.planalto.gov.br/ccivil_03/constituicao/constituicao.htm Acesso em 23.08.19

${ }^{15}$ AUGUSTO, Luís Gustavo Henrique. Participação social no processo legislativo federal: um estudo da Comissão de Legislação Participativa (CLP), da Comissão de Direitos Humanos e Legislação 
Há também outros institutos da democracia direta que também são demasiadamente relevantes, quais sejam, o veto popular, o recall e o recall judicial. Sobre esses mecanismos, Dalmo de Abreu Dallari explica:

Pelo veto popular, dá-se aos eleitores, após a aprovação de um projeto pelo Legislativo, um prazo, geralmente de sessenta a noventa dias, para que requeiram a aprovação popular (...). O recall é uma instituição norteamericana, que tem aplicação em duas hipóteses diferentes; ou para revogar a eleição de um legislador ou funcionário eletivo, ou para reformar decisão judicial sobre constitucionalidade de lei (...). O recall judicial, bastante controvertido, foi preconizado por Theodore Roosevelt, em 1912, numa de suas campanhas eleitorais. Segundo sua proposição, as decisões de juízes e Tribunais, excluídas apenas a Suprema Corte, negando a aplicação de uma lei por julgá-la inconstitucional, deveriam ser anuladas pelo voto da maioria dos eleitores. Ocorrida essa anulação a lei seria considerada constitucional, devendo ser aplicada ${ }^{16}$.

Estes institutos, sem dúvida, fortalecem o exercício do poder político da população, de modo a proporcionar maior amplitude da democracia. Os cidadãos em conjunto, deliberam diretamente as propostas que consideram justas ou adequadas para toda uma sociedade.

Numa democracia representativa ou indireta, os instrumentos de participação das democracias direta e semidireta estão ausentes ou estão diluídos. Nesse modelo, a população concede um mandato, a determinados membros do povo, para exercerem o papel de representante político, a fim de tomar as decisões, em nome de seus eleitores.

A distinção entre governantes e governados, na democracia representativa, é bem explícita, de modo que o povo atua como delegatário das decisões coletivas, transferindo-as para os governantes, os quais terão o poder político de influência, execução e elaboração das leis e na estrutura jurídico-política do Estado.

A democracia representativa sofreu severas críticas de Rousseau, visto que para ele, uma democracia excelente teria de ser direta e sem mediadores. A participação efetiva do povo, nas decisões políticas, era a expressão soberana do caráter democrático.

Nesse sentido, Darcy Azambuja expõe:

Participativa $(C D H)$ e da iniciativa popular de lei. São Paulo, 2015. p. 16. Disponível em http://bibliotecadigital.fgv.br/dspace/handle/10438/13706?show=full Acesso em 23.08.19

${ }^{16}$ Op.cit. p.154, 155. 
(...) Rousseau, o pai da democracia moderna, condenara definitivamente o regime representativo. O autor do "Contrato Social" considerava-o uma contrafação lastimável da democracia. Segundo ele, o povo é o único soberano e a vontade geral do povo a expressão viva da soberania. Ora, a vontade é de si mesma inalienável e intransmissível. Ninguém pode pretender exprimir a vontade soberana do povo senão o próprio povo ${ }^{17}$.

Entretanto, Rousseau tinha em mente a existência de uma assembleia constituída pelo povo, capaz de incorporar e exprimir sua vontade política.

O ideal da democracia representativa encontra suas origens na Inglaterra, onde a monarquia foi gradativamente perdendo seus poderes para o Parlamento, que, basicamente, constituía-se de um modelo de representação coletiva.

Por certo, havia um regime feudal dominado pelos senhores feudais, o que fez com que o povo e os burgueses buscassem apoio do rei, contra as arbitrariedades daqueles. Essa busca pelo apoio real gerou o regime monárquico absolutista. $\mathrm{O}$ rei, em raros momentos, convocava assembleias, mas estas não tinham forças suficientes para limitar suas atividades. Os conflitos, as guerras e os abusos da coroa, fizeram com que burgueses, nobres e o povo se unissem contra a monarquia, requerendo limite para seus abusos de poder.

Posteriormente, surge o parlamento inglês, cuja composição era formada por nobres, o alto clero e representantes do povo, oriundos dos condados e dos burgos. $\mathrm{O}$ Parlamento então seria um órgão de representação nacional, onde toda nação estava presente.

Acerca das deliberações do Parlamento inglês, Darcy Azambuja aponta:

Ora, de um lado, para os reis era mais rápido e fácil pedir as contribuições de que necessitavam aos representantes das diversas classes reunidas no Parlamento do que requisitar diretamente no país. Por seu lado, o Parlamento, para votar as contribuições, pedia compensações que eram sempre limitação da autoridade real. Quando os reis, arruinados com as guerras continentais, tornaram-se fracos, o Parlamento não pedia, exigia, como aconteceu com João Sem Terra. E assim obteve todas as prerrogativas que caracterizam o regime representativo e os Parlamentos modernos, isto é, além dos direitos individuais, a competência exclusiva para elaborar e votar leis. Através dessa

\footnotetext{
${ }^{17}$ AZAMBUJA, Darcy. Teoria Geral do Estado. 2001. p.274.
} 
evolução, que foi longa e acidentada, em que ora o rei, ora o Parlamento era vencedor, a monarquia inglesa passou de absoluta e ilimitada a constitucional e limitada, e o regime representativo se organizou ali séculos antes do Continente ${ }^{18}$.

O Parlamentarismo foi o que deu origem aos modelos representativos que hoje existem. Esse modelo representativo foi sendo aperfeiçoado, ao longo do tempo, por meio do sufrágio universal e do mandato eletivo.

\subsection{Modelos representativos atuais}

Acerca do mandato eletivo, há várias discussões sobre sua natureza jurídica. Quando eleitos, os políticos, que durante a campanha eleitoral fizeram inúmeras promessas para a obtenção do voto, e estariam, de certo modo, assumindo um compromisso com seu eleitorado, devendo, portanto, cumprirem com suas ofertas de governo. A discussão gira em torno de se a natureza do mandato político é semelhante ao mandato do direito privado, onde uma das partes exige uma contraprestação dos serviços prestados, isto é, o mandante outorga poderes de representação ao mandatário, para que este seja representante de seus interesses particulares. Esse mandato é conferido por meio do instrumento da procuração ${ }^{19}$.

No mandato particular, "o mandatário é obrigado a aplicar toda sua diligência habitual na execução do mandato, e a indenizar qualquer prejuízo causado por culpa sua ou daquele a quem substabelecer, sem autorização, poderes que devia exercer pessoalmente", conforme o que dispõe o artigo 667 do Código Civil. Percebe-se que aquele que recebe o mandato possui obrigações específicas a serem cumpridas, do mesmo modo, aquele que confere o mandato "é obrigado a satisfazer todas as obrigações contraídas pelo mandatário, na conformidade do mandato conferido, e adiantar a importância das despesas necessárias à execução dele, quando o mandatário lho pedir"(art.675 do Código Civil).

Há, nesse tipo de mandato, obrigações e deveres recíprocos de caráter gerencial do instrumento de procuração, e pode ser facilmente manipulado pelas partes, vindo a

\footnotetext{
${ }^{18}$ AZAMBUJA, Darcy. Op.cit. p.264.

19 BRASIL. Código Civil. Lei $N^{o}$ 10.406, de 10 de Janeiro DE 2002. Art. 653. Opera-se o mandato quando alguém recebe de outrem poderes para, em seu nome, praticar atos ou administrar interesses. A

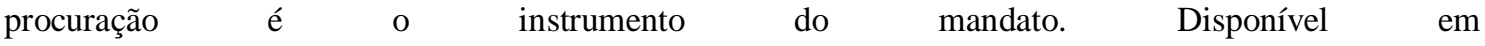
http://www.planalto.gov.br/ccivil 03/leis/2002/110406.htm Acesso em 03.09.19
} 
ser cessado pela revogação ou pela renúncia, isto é, tanto o outorgante, quanto o mandatário, podem romper seus direitos e obrigações entre si.

O mandato também pode ser cessado pela morte ou interdição de uma das partes; pela mudança de estado que inabilite o mandante a conferir os poderes, ou o mandatário para os exercer; pelo término do prazo ou pela conclusão do negócio (art. 682, I, II, III e IV do Código Civil).

Todavia, destaca-se que, tratando-se de mandato eletivo de caráter político, não há vinculação de qualquer natureza, com aqueles que lhe conferem o mandato, pela via eleitoral. As previsões do instituto do mandato privado não se aplicam, em nenhuma medida, ao mandato político, pois não é possível aos eleitores exigirem ou estabelecerem disposições e observações que deverão ser atendidas pelo mandatário. $\mathrm{O}$ mandatário político não estaria subordinado ou vinculado, de nenhuma forma, aos seus eleitores.

Sobre o mandato político, José Geraldo Brito Filomeno assevera:

\begin{abstract}
No caso do mandato político, entretanto, e até que novas normas constitucionais lhe sejam impostas - como a hipótese de do recall, por exemplo -, é de caráter institucional e imperativo, o que equivale a dizer que todas as condições que o regulam são ditadas pelas normas constitucionais e infraconstitucionais, como é o caso, na segunda hipótese, da chamada "lei orgânica dos partidos políticos" e "código eleitoral”, recentemente modificados $^{20}$.
\end{abstract}

Dentro da perspectiva do mandato político, num regime de democracia representativa, o mandatário, adquirindo a outorga popular, não está vinculado aos interesses de seus eleitores, pois não há uma relação de direito privado entre eles. O mandato tem caráter eminentemente público e contém aspectos jurídicos e políticos conjugados em si. Além disso, o mandato político contém características de ser irrevogável, livre, geral, e não há necessidade de que os mandantes confirmem quaisquer disposições a ele inerentes.

Ante as características inerentes ao mandato político, vale ressaltar que o mandatário expressa a vontade de todo povo, independentemente de ter sido eleito por uma parcela dele. A aquisição do cargo político, possibilita que ele tome decisões em

\footnotetext{
${ }^{20}$ FILOMENO, José Geraldo Brito. Manual de Teoria Geral do Estado e Ciência Política, 2003. p. 112, 113.
} 
nome de todos os cidadãos ou de parte deles, dependendo do cargo público e da esfera de poder que ele ocupará.

O portador do mandato, ao ser eleito, não possui, como ressaltado, vinculo algum com seus eleitores, não sendo obrigado a dar explicações sobre suas escolhas políticas, nos assuntos em que delibera, o que o torna independente e autônomo.

Conforme destacado, o mandato possui caráter irrevogável, tendo em vista não existir no Brasil o instituto do recall, que proporcionaria a anulação do mandato pelos eleitores. Sobre o tema, Dalmo de Abreu Dallari escreve:

Em regra, o mandato é irrevogável, sendo conferido por prazo determinado. A exceção a esse princípio é o recall, que dá possibilidade à revogação do mandato por motivos exclusivamente políticos. Esse instituto, entretanto, só existe em alguns Estados da federação norte-americana, e é de alcance muito restrito, não chegando a desfigurar o princípio geral da irrevogabilidade ${ }^{21}$.

Apesar do recall ser uma marca do ideal da democracia direta, tendo em vista que permite a participação direta dos eleitores e seu controle político sobre aquele que adquire o mandato, sua difusão, nas esferas de governo, geraria, em alguma medida, uma instabilidade institucional, pois demandaria uma substituição rápida daquele que teve seu mandato revogado, e exigiria tempo e mobilização dos eleitores para estabelecer um novo pleito.

Seria bastante confortável a possibilidade de revogar mandatos políticos, quando os eleitos não atendem os anseios do povo, deixando de os representar, em virtude de seus interesses particulares. A insatisfação com os políticos não é pouca e causaria controvérsias das mais acirradas, nas disputas eleitorais.

Há também o problema da má escolha política, pois, sem dúvida, não se pode mensurar a capacidade política de um candidato, antes de vê-lo em exercício político. Os critérios de elegibilidade são limitados, diante do que se espera de alguém que será o representante do povo e da sociedade geral. A má escolha política pode ser catastrófica, diante do despreparo político do candidato. As consequências de uma má gestão não podem ser cessadas de pronto, pois o sistema eleitoral brasileiro não contém institutos de revogação expressa de mandato político.

\footnotetext{
${ }^{21}$ DALLARI, Dalmo de Abreu. Op. cit. p. 158.
} 
O que ocorre, constantemente, é que o eleitor possui uma certa indignação em si mesmo e exterioriza suas tendências por meio de uma escolha irracional em quem votar. Sobre essa questão Jorge Vianna Monteiro aponta:

(...) diferentemente do consumidor em um mercado convencional de bens e serviços, o eleitor "lança" seu voto em uma enorme área comum e, portanto, o resultado final (a política pública estabelecida pela representação eleita) traduzirá "o conteúdo médio" desse pool de votantes. Em decorrência, nada impede que em uma democracia o eleitor se comporte não racionalmente, apoiando sua decisão de voto em qualquer tipo de crença subjetiva, sem que, para tanto, ele incorra em qualquer custo; seu benefício será mais psicológico, do que material ${ }^{22}$.

O sufrágio universal sofreu considerável ampliação, ao longo do tempo. $\mathrm{Na}$ transição entre monarquia e república, no Brasil, apenas poucos tinham o poder de voto. Inicialmente os dotados de propriedade é que possuíam a primazia na escolha dos representantes, sendo apenas homens. Analfabetos e mulheres estavam impedidos de exercerem sua cidadania, através do voto.

Todavia, as transformações sociais possibilitaram um crescimento da participação política da população, sendo o voto um direito de mulheres, homens, jovens, ricos, pobres etc.

Destaca-se que, no âmbito nacional, houve uma crescente expansão do processo democrático. Na República Velha, a participação democrática por meio do voto era reduzida, as mulheres não podiam votar. Estima-se que, nesse período, havia em média de 3 a 5\% de eleitores. Na revolução de 1930, período que marca o fím da chamada República Velha e o início da "era Vargas", houve uma ampliação na participação democrática, $15 \%$ votavam nesta época, ficando de fora os analfabetos. Vale ressaltar que houve enorme restrição ao funcionamento da democracia, tendo em conta que a maior parcela da sociedade era analfabeta ${ }^{23}$.

Entrementes, em 1964, inicia-se o período do regime militar, que ocasionou o sepultamento da democracia. O regime fez com que houvesse significativa diminuição das liberdades, excesso de repressão, governos marcados pelo instituto do nepotismo, além de, haver proibição por lei de criação de mais partidos políticos no Brasil.

\footnotetext{
${ }^{22}$ MONTEIRO, Jorge Vianna. Escolhas públicas de má qualidade e democracia representativa. p. 789

${ }^{23}$ Disponível em https://www.youtube.com/channel/UCN68rShHGOW--cjJ7_oY0AQ/featured Acesso em 10.11.19.
} 
A justificativa para o golpe de 1964 baseou-se numa suposta ameaça comunista que visava subverter a ordem nacional e a alegação de que o então presidente deposto, João Goulart, tinha discursos de espectro esquerdista.

Osvaldo Estrela Viegaz disserta sobre este período e o que ocorria no mundo:

\begin{abstract}
O momento mundial não era dos melhores. Os países se dividiam entre capitalistas e comunistas e mesmo aqueles que não tinham assumido ainda o seu lado na história tinham, por sua vez, de tomar partido de alguma maneira. Todo o Leste Europeu encontrava-se sob o manto da Cortina de Ferro Soviética, enquanto o restante da Europa seguia os preceitos do "Liberalismo Democrático Estadunidense". Berlim estava dividida por um muro e assim permaneceu até 1989. Separava não somente as ideologias do Oeste Capitalista das do Leste Comunista, como também e principalmente, filhos, pais e avós uns dos outros ${ }^{24}$.
\end{abstract}

O regime militar findou-se em 1985, dando início ao período da Nova República, que proporcionou a ressurreição da democracia e trabalhou para o progresso da redemocratização do Brasil. Em 1988 é promulgada uma nova Constituição Federal.

Com esse avanço nacional, a participação política foi ampliada de forma gigantesca, quase $50 \%$ da população passava a votar, no período Collor.

Na Nova República, os direitos às liberdades foram restaurados, ocasionando o seu crescimento massivo. A Constituição de 1988 possibilitou a ampla participação política, prevendo, em seu bojo, o pluripartidarismo, tornando possível a criação de partidos políticos de natureza diversas, inclusive comunistas. A liberdade de expressão usufruída pelas mídias sociais foi determinante no exercício da critica ao governo, bem como proporcionou a fiscalização das suas ações e de seus agentes, pela sociedade.

Apesar de o Brasil ter adotado um modelo de democracia participativa ou semidireta, percebe-se que no aspecto da representatividade, há uma onda de crise.

Certo é que o modelo representativo não abarca toda a nação, mas, tão somente, parcela dela, quando, nas eleições, vota-se em candidatos específicos, que não estarão vinculados de nenhuma maneira a seus eleitores. Há uma relação de independência entre o político eleito e seus eleitores. O que se nota é que, no exercício de seu mandato político, o representante atende interesses, que, frequentemente, não é o

\footnotetext{
${ }^{24}$ VIEGAZ, Osvaldo Estrela. Ameaça vermelha: Marxismo e o pseudo terror comunista universitário Subversão ou liberdade de expressão? in Fronteiras entre a eficiência jurídica e a censura: estudos sobre o Supremo Tribunal Federal e a ditadura. São Paulo, Universidade Nove de Julho, 2016. p. 21.
} 
interesse coletivo, mas sim de grupos específicos, ou até mesmo interesses puramente pessoais.

Estudiosos sustentam que o modelo de democracia representativa, não é um regime representativo, considerando-se que os que adquirem mandato político não estão subordinados aos cidadãos que os elegeram, usufruindo de sua independência, da maneira que acharem conveniente.

Neste sentido, Darcy Azambuja ensina:

\begin{abstract}
Assim, já a própria eleição dos representantes, se lhes conferia algum mandato representativo, não realizava por certo a representação de toda a nação, nem de todos os seus cidadãos, mas de uma parte deles. O mais grave, porém é que, efetuada a eleição, pela própria índole do regime, os pseudorepresentantes passam, de fato, a constituir a nação, pois todos os seus atos e resoluções valem como se emanassem diretamente dela. Esta, como que desaparece, anula-se legalmente e, se alguma vez tem opinião sobre qualquer assunto de ordem pública, vê frequentemente os seus representantes emitirem votos inteiramente contrários, sem que lhes reste nenhum meio legal de fazer valer sua vontade ${ }^{25}$.
\end{abstract}

A representatividade encontra brechas, no seu modo de execução. Ao criar ou votar projetos de lei, os eleitos não consultam seu eleitorado para tomar a decisão coletivamente, ele, possuindo um caráter de autonomia, deliberará em nome de todos, mesmo que isso não seja favorável ou beneficie aos cidadãos.

A população agirá como fiscal, dado em que os atos políticos tornam-se públicos e divulgados pela imprensa, que adquiriu a atribuição de dar publicidade ao que se passa nos bastidores do poder. Consequentemente, os eleitores tornam-se meros expectadores das relações políticas de poder, não podendo, de nenhuma maneira, impedir qualquer ato nocivo daquele que recebeu o mandato.

Quando os portadores do mandato político desagradam ao eleitorado, cabe a eles, na próxima legislatura, substituir seu representante por outro candidato, que atenda a seus interesses.

A representatividade no Brasil poderia ser contestada por meio de instrumento como o veto popular ou recall, de tal forma que pressionaria seus representantes a se

\footnotetext{
${ }^{25}$ AZAMBUJA, Darcy. Op. cit. p. 276.
} 
manterem fiéis às suas promessas de campanha, e, então, atendendo aos interesses coletivos.

Sobre a reeleição como instrumento da democracia, Michel Temer assevera:

\begin{abstract}
Reeleger significa, politicamente, aprovar atuação do governante. É juízo de valor. O eleitor avalia, para conceder novo mandato, vários fatores: administração eficiente, lisura de procedimento, compromisso com metas etc. Não é, como no caso da primeira eleição, esperança de bom governo. É aprovação ou desaprovação em face de governo realizado. É a reeleição, sim, instrumento saudável para a democracia porque leva o eleitor a votar em situações, já comprovadas. O tema da reeleição, portanto, é da maior importância, já que diz respeito ao exercício mais transparente da cidadania ${ }^{26}$.
\end{abstract}

As falhas na representatividade demonstram, cada vez, mais a necessidade de participação popular, nas decisões políticas, pois urge a necessidade de proporcionar à sociedade a capacidade de um pensamento coletivo e não meramente individual, como se pensou no berço da teoria democrática.

O processo de participação, nas decisões políticas, deve basear-se na democratização do poder político exercido pelo povo. É interessante que se crie mecanismos de participação, para que a sociedade, de um modo geral, contribua e saiba agir, frente aos grandes desafios que a política moderna enfrenta.

O Estado agora não deve ser visto como inimigo social, tampouco ele deve comportar-se de modo tirano, ao ponto de intervir nas liberdades individuais. O Estado deve ser o mediador das tensões sociais e deve, portanto, promover o equilíbrio e servir à sociedade e o bem comum.

Os agentes políticos devem comportar-se de modo ético, capaz de trazer estabilidade para as instituições em que eles estão inseridos, a fim de gerar segurança e bem-estar.

É necessário que a população, seus grupos ou movimentos sociais organizemse para que se estabeleçam diretrizes hábeis, na participação democrática.

Sobre a participação democrática, Fernando Henrique Cardoso expõe:

Assim, a fase da democracia participativa implica, primeiro, em reconhecer o primado da democracia, a existência de formas legitimadas, de estruturas em que se tenha a divisão dos poderes, os partidos etc. Mas isso não basta. É

\footnotetext{
${ }^{26}$ TEMER, Michel. Democracia e Cidadania. São Paulo, 2006. p. 28
} 
imprescindível produzir os mecanismos pelos quais também, em cada nível de decisão, os grupos interessados se organizem. Evidentemente pode-se formular uma descrição das maneiras possíveis de participação, mas o xis do problema não está tanto nas formas de participação e sim no entendimento do que significa essa participação e como se faz necessária ${ }^{27}$.

A democracia sofre modulações, de acordo com a ideologia dominante no poder. Isso faz com que seja necessária a adoção de regras e critérios, para que se equilibre as relações, por isso, a atuação de uma oposição num modelo representativo é demasiadamente importante.

Vislumbra-se que, ao ver um grupo político predominante num órgão representativo, ocorre a supressão ou até mesmo no impedimento de maior atuação de outros grupos, sejam na elaboração das leis ou na execução delas.

De tal sorte, por haver desequilíbrio entre as relações de representação, aqueles que se acham violados ou suprimidos, devem recorrer aos mecanismos judiciais, para alcançar seus objetivos, vez que num modelo de separação de poderes, com freios e contrapesos, não pode haver excessos de atuação de um órgão em detrimento do outro.

Para se assegurar que as leis tenham sua plena execução e cumprimento, é que elas passam pelo controle de constitucionalidade do Supremo Tribunal Federal.

O Supremo Tribunal Federal servirá como o guardião da Constituição, além de garantir o equilíbrio entre os poderes, e, ainda mais, como garantidor dos direitos e garantias fundamentais.

A crise de representatividade acaba tendo como solução as demandas judiciais, ingressadas perante o STF que suprirá a omissão, ou, até mesmo, as ações do Poder Legislativo, que acaba por não atender as expectativas dos eleitores, sendo que este é o órgão de representação legítimo da nação.

Ao ter essa crise institucional, na casas legislativas, o Supremo Tribunal Federal agirá como órgão de representação democrática, na garantia de direitos e proteção deles, diante de uma vulnerabilidade que determinados grupos e seguimentos da sociedade sofrem.

A judicialização das políticas públicas e o ativismo judicial surgem num contexto de omissão das instituições, e, enfim, torna a Suprema Corte capaz de exercer

\footnotetext{
${ }^{27}$ CARDOSO, Fernando Henrique. A democracia necessária. 1985. p. 61.
} 
o papel democrático, em relação àqueles que não estão devidamente representados, nos órgãos legislativos. 


\section{NEOCONSTITUCIONALISMO E DEMOCRACIA}

O neoconstitucionalismo tem como objetivo alcançar maior eficácia da Constituição, superando a ideia de limitação do poder político. A finalidade é garantir que os direitos fundamentais sejam efetivamente concretizados, não se limitando apenas ao aspecto formal do texto.

A concepção neoconstitucionalista objetiva uma transição no paradigma orientador de um Estado. A mudança passará de um Estado das leis para um Estado constitucional. A Constituição, nesse modelo, passa a ser o centro de todo o sistema estatal. As instituições públicas e as leis deverão observar rigorosamente as prescrições constitucionais e ainda estar de acordo com suas disposições. De certo, a instituição político-jurídica será de implementação de um Estado constitucional de direito, devendo tudo ser de acordo e interpretado a partir da Constituição.

Destaca-se que o neoconstitucionalismo é também nominado de póspositivismo ou constitucionalismo pós-moderno.

A concepção apresentada revela que o neoconstitucionalismo constitui um conceito aberto, e que vem sendo construído ao longo do tempo, de modo que sua existência implica na evolução do direito constitucional.

No Brasil, têm-se como marco histórico do novo constitucionalismo a transição do regime militar para uma democracia constitucional, tendo como fundamento a promulgação da Constituição Federal de 1988, que proporcionou o período de maior estabilidade entre as instituições no país.

Nesse sentido, Luís Roberto Barroso assevera:

\footnotetext{
No caso brasileiro, o renascimento do direito constitucional se deu, igualmente, no ambiente de reconstitucionalização do país, por ocasião da discussão prévia, convocação, elaboração e promulgação da Constituição de 1988. Sem embargo de vicissitudes de maior ou menor gravidade no seu texto, e da compulsão com que tem sido emendada ao longo dos anos, a Constituição foi capaz de promover, de maneira bem-sucedida, a travessia do Estado brasileiro de um regime autoritário, intolerante e, por vezes, violento para um Estado democrático de direito ${ }^{28}$.
}

\footnotetext{
${ }^{28}$ BARROSO, Luís Roberto. Op. cit. p. 3.
} 
No caso estrangeiro, especificamente o da Europa, o processo de redemocratização e do estabelecimento de um Estado Democrático de Direito tem, como marco histórico, o período pós-guerra, com o advento da Lei Fundamental de Bonn, da Alemanha, de 1949, e a instituição do Tribunal Constitucional Federal de 1951. Na Itália, houve o advento da Constituição de 1947 e o estabelecimento da Corte Constitucional de 1956. Tem-se também o exemplo de Portugal, com a Constituição de 1976, e a da Espanha de 1978.

Além do marco histórico, o neoconstitucionalismo possui também caráter filosófico, tendo como base o pós-positivismo.

O pós-positivismo encontra inspiração em duas vertentes de pensamento, o jusnaturalismo e o positivismo. É, a partir do século XVI, que o jusnaturalismo moderno se desenvolve, unindo dois pressupostos anteriormente antagônicos, a lei e a razão. Essa fusão deu origem à filosofia natural do Direito. As revoluções liberais encontraram inspiração, nos princípios de justiça universalmente válidos. O ápice desse fenômeno deu-se com o advento das Constituições escritas e a elaboração dos códigos de leis.

Luís Roberto Barroso diz:

Considerado metafísico e anticientífico, o direito natural foi empurrado para a margem da história pela ascensão do positivismo jurídico, no final do século XIX. Em busca de objetividade científica, o positivismo equiparou o Direito à lei, afastou-o da filosofia e de discussões como legitimidade e justiça e dominou o pensamento jurídico da primeira metade do século XX. Sua decadência é emblematicamente associada à derrota do fascismo na Itália e do nazismo na Alemanha, regimes que promoveram a barbárie sob a proteção da legalidade. Ao fim da $2^{\mathrm{a}}$. Guerra, a ética e os valores começam a retornar ao Direito ${ }^{29}$.

O positivismo pregava uma leitura exclusivamente legalista, e afastava qualquer possibilidade de união entre outras ciências e o direito, que era enxergado estritamente como a lei escrita, sem haver margem ampla de interpretação.

Com o enfraquecimento da concepção positivista, o direito passou a incorporar, dentro de sua ideologia, uma leitura moral do direito, nascendo a noção de pós-

\footnotetext{
${ }^{29}$ BARROSO, Luís Roberto. Op. cit. p. 4.
} 
positivismo, que não descartou a letra fria da lei, mas concebeu oportunidade de uma leitura mais ampla, na aplicação do direito.

O objetivo do pós-positivismo é transpassar a legalidade estrita, sem desprezar a letra da lei. Neste cenário, procura-se combater teses juspositivistas que visem separar o Direito e a moral, indicando fundamentos transparentes para a concretização normativa de valores metajurídicos.

A teoria de justiça deve inspirar a interpretação e aplicação do direito no ordenamento jurídico, todavia não podem suportar que voluntarismos ou personalismos, sobretudo, os judiciais, passem a ser critérios objetivos. Ora, a atribuição de normatividade aos princípios unidos aos valores e regras constitucionais formam uma nova hermenêutica constitucional, proporcionando o alicerce e o desenvolvimento dos direitos fundamentais, sob a iluminação da dignidade da pessoa humana. Unir a filosofia e o direito, representa uma reaproximação necessária.

No que toca ao aspecto teórico como marco fundamental ao neoconstitucionalismo, há três grandes transformações: a) o reconhecimento de força normativa à Constituição; b) a expansão da jurisdição constitucional; c) o desenvolvimento de uma nova dogmática da interpretação constitucional ${ }^{30}$.

Em relação à força normativa da Constituição, destaca-se que a norma constitucional passa a ter status de norma jurídica, possuindo caráter de imperatividade, se eventualmente houver descumprimento de suas disposições, será obrigatório seu cumprimento forçado. Percebe-se uma mudança de paradigma, a Constituição deixa de ser um documento meramente político, tornando-se norma jurídica com caráter imperativo, e seu descumprimento gera a execução forçada, ao atendimento de suas disposições.

Sobre a expansão da jurisdição constitucional, observa-se que havia um modelo de supremacia do Poder Legislativo, em meados da década de 1940, na Europa, cuja concepção baseava-se na lei como expressão da vontade geral do povo. Com o advento das constituições, bem como o exemplo americano de modelo constitucional, um novo conceito surgiu, qual seja, o da Supremacia da Constituição. Nota-se que a constitucionalização dos direitos fundamentais, deveria ficar isenta do processo político majoritário. A proteção constitucional cabe principalmente ao Poder Judiciário. É certo

\footnotetext{
${ }^{30}$ BARROSO, Luís Roberto. Op. cit. p. 5.
} 
que vários países europeus adotaram um modelo peculiar de controle de constitucionalidade, relacionando-os à criação de tribunais de jurisdição constitucional.

Com base na interpretação constitucional e sua novidade dogmática, houve uma superação no modelo de subsunção das normas, nos casos concretos, como regra abstrata. O juiz pratica uma operação de interpretação constituída por cláusulas gerais, princípios, e resolve o confronto entre as normas constitucionais conflitantes, cujas decisões são pautadas na argumentação e na ponderação.

Logo, o neoconstitucionalismo reaproxima o direto e a moral, objetivando a concretização de valores universais, a fim de assegurar o exercício do direito e seu instrumento de poder. Nesse sentido, o Poder Judiciário atua de modo proativo, a fim de promover os direitos fundamentais, buscando viabilizar a justiça social, diante das consequências que a ruptura entre o direito e a moral causou.

Todavia, o neoconstitucionalismo e seus defensores têm sofrido críticas, porque, essa leitura do direito constitucional, não é nada nova, mas se trata de um esforço exagerado, em se adotar uma nomenclatura desprovida de aspecto científico.

Desse modo, o neoconstitucionalismo termina sendo usado como um artifício retórico, para que o julgador possa ter ampla margem de atuação, sem as limitações que a lei impõem ao julgamento do caso concreto.

$\mathrm{Na}$ hermenêutica neoconstitucional, os princípios são dotados de uma carga valorativa mais importante e eficaz do que as regras, sendo usados para modular os argumentos de uma decisão judicial, a bel prazer do julgador.

Criticando o fenômeno do neoconstitucionalismo, Carlos Bastide Horbach, acentua:

Na interpretação da lei ou da Constituição, os "neo-constitucionalistas" separam o termo do conceito, o conceito do preceito, o preceito da norma, a norma do texto e o texto do contexto, para, ao final dessa operação, fazer com que o dispositivo afirme exatamente o que desejam e, não raro, o contrário do que nele está escrito ${ }^{31}$.

O neoconstitucionalismo estaria revestido de características exageradas das atribuições jurídicas/políticas daqueles que são responsáveis pela interpretação da Constituição e das leis, isto é, aquele que tem a atribuição precípua de concretizar, em

\footnotetext{
${ }^{31}$ HORBACH, Carlos Bastide. A nova roupa do direito constitucional: neo-constitucionalismo, póspositivismo e outros modismos. 2007, p. 8 .
} 
tese, os direitos fundamentais, teria a prerrogativa máxima de dar a intepretação ao texto normativo, da melhor forma que lhe convém.

Sobre a ideia de interpretação que os neoconstitucionalistas tem, Carlos Bastide Horbach, destaca o entendimento de Manoel Gonçalves Ferreira Filho, que ressalta:

\begin{abstract}
"Na verdade, frases como 'a interpretação é ato de vontade', 'o intérprete produz a norma' são extremamente enganosas. Justificam-se quando significam, 'entre vários sentidos possíveis, dada a ambiguidade do enunciado, que o legislador escolhe um deles; e como escolher é ato de vontade, a interpretação é um ato de vontade'; ou, 'lendo o enunciado, o intérprete dá sentido às expressões que ele usa e, assim, produz o sentido da norma, por isso ele produz a norma' (que não é evidentemente o conjunto de sinais expressos no papel). Mas são absurdas se querem dizer que o intérprete faz a norma de acordo com sua vontade, ou o justo que pressupõe. Ou, pelo menos, renegam o sistema do Estado de Direito, porque negam o primeiro de seus princípios - o da legalidade; contestam a democracia, na qual a lei é expressão da vontade geral; abandonam a separação de poderes, que reserva ao legislador o estabelecimento da lei" ${ }^{32}$.
\end{abstract}

Entretanto, a atuação dos neoconstitucionalistas segundo os críticos, é de abandonar as regras e o texto da lei ou norma. Nesse sentido, o texto normativo termina por adquirir valor secundário, na aplicação do direito ao caso concreto. Os interpretes da Constituição incorporam o desejo de serem os protagonistas dos anseios sociais e acabam sendo influenciados pela opinião pública, ao prolatarem suas decisões.

Entrementes, o neoconstitucionalismo é utilizado especialmente por integrantes do Supremo Tribunal Federal, já que suas decisões são baseadas, não só nas regras, mas também nos princípios, e isto, decerto, traz harmonia institucional.

A aplicação do direito, num país democrático, serve como fator de equilíbrio e freios para as arbitrariedades que as instituições políticas possam vir a cometer, sendo que, sua utilização, é mais do que necessária, diante dos conflitos sociais existentes no Brasil, que é uma das nações democráticas mais desiguais do mundo.

Nesse sentido, Lenio Luiz Streck adverte:

\footnotetext{
${ }^{32}$ Ferreira Filho, Manoel Gonçalves. Apud HORBACH, Carlos Bastide. Em Manoel Gonçalves Ferreira Filho. Curso de direito constitucional, 2005, p. 379.
} 
Em uma democracia estável, o direito ocupa um papel central na organização da engenharia institucional, ao definir as condições mínimas para o funcionamento do sistema político. Ao mesmo tempo, o reconhecimento de novos direitos pelo Constitucionalismo Contemporâneo ocasiona uma atuação mais destacada do Poder Judiciário; essa situação, muitas vezes, é confundida pela comunidade jurídica como uma justificativa para decisões sem qualquer critério de racionalidade, baseadas na mais pura discricionariedade judicial. Torna-se necessário enfrentar os desafios que tem o Poder Judiciário para - no limite, em face da incompetência dos demais Poderes - contribuir para a concretização dos direitos fundamentais ${ }^{33}$.

Destarte, o neoconstitucionalismo, basicamente, é considerado como um artificio hermenêutico, que tem gerado insegurança jurídica nas decisões judiciais com temas sensíveis.

As críticas, em relação às decisões do Supremo Tribunal Federal, não se esgotam. Sobre elas, Conrado Hubner Mendes cunhou a expressão "populisprudência", e a explica:

\footnotetext{
Em poucas palavras, "populisprudência" é o populismo disfarçado de jurisprudência. O populismo envolve uma série de técnicas retóricas para despertar a paixão, os afetos, a adesão incondicional dos súditos. Serve para buscar apoio de um certo grupo de pessoas que o populista chama de "povo", excluindo todos que não estejam com ele como "anti-povo" ou "impuros". O populismo não costuma ser, e não pode ser o papel do juiz. A "populisprudência" é faceta do comportamento individual de certos juízes, mas às vezes também do sistema de justiça em geral, tentando arregimentar apoio popular para uma dada causa, para uma dada decisão, para um dado interesse que o sistema de justiça abraçou para si mesmo ${ }^{34}$.
}

A utilização dos princípios como valor normativo superior às normas tem desencadeado o fenômeno do ativismo judicial, cuja função acarreta a exacerbação das competências jurisdicionais, interferindo diretamente nas atribuições dos outros poderes. Por outro lado, o ativismo judicial tem garantido que determinados grupos tenham garantias constitucionais, considerando que, se esperassem pela atuação

\footnotetext{
${ }^{33}$ STRECK, Lenio Luiz. Entre o ativismo e a judicialização da política: a difícil concretização do direito fundamental a uma decisão judicial constitucionalmente adequada. 2016. p. 721.

${ }^{34}$ MENDES, Conrado Hubner. Entrevista à Revista CAASP, 36a edição. Agosto de 2018, p.7-8.
} 
representativa do Poder Legislativo, a fim de criar uma regra que proporcionasse a proteção desses grupos, ficariam no limbo da espera.

De outra sorte, as práticas de ativismo judicial vêm valendo-se de mecanismos constitucionais, para a sua promoção. O controle de constitucionalidade tem sido a ferramenta pela qual o Supremo Tribunal Federal vem agindo na promoção do ativismo judicial, bem como na judicialização das políticas públicas.

\subsection{Os Controles Difuso e Concentrado de Constitucionalidade De Normas}

Em alguns países, a alteração do texto constitucional exige um procedimento mais rigoroso e um conjunto de formalidades, quando verifica-se a existência de uma Constituição rígida. Essa dificuldade para que se altere o texto da Carta Magna foi estabelecida pelo próprio poder constituinte originário, para que houvesse maior segurança jurídica. Em contrapartida, a modificação da legislação infraconstitucional possui um procedimento mais simples.

Nos ordenamentos jurídicos que adotaram uma Constituição rígida, há o conjunto de formalidades especiais para que se altere o texto constitucional, isso se dá pelo fato de haver o princípio da supremacia da Constituição, que coloca as normas constitucionais acima de todas as outras normas elaboradas no ordenamento.

Vale destacar que nos ordenamentos jurídicos que adotaram uma Constituição flexível, não há formalidades especiais para a alteração do texto constitucional. Nesse contexto, as normas constitucionais possuem o mesmo status formal das normas infraconstitucionais. Nas constituições flexíveis, o procedimento para sua alteração é o mesmo dos dispositivos das leis ordinárias, não se exigindo qualquer medida excepcional ou rigorosa para a alteração do bojo da Carta Política. A Constituição flexível e as leis ordinárias, possuem o mesmo status formal. Quando da aprovação de novas leis, estas revogam ou derrogam todas as normas anteriores que tenham incompatibilidade, mesmo se essas normas sejam constitucionais.

$\mathrm{Na}$ Inglaterra, por exemplo, que possui uma Constituição flexível, são incabíveis mecanismos de impugnação ao texto constitucional, pois o parlamento constitui-se, respectivamente, no poder Legislativo e Constituinte. Nesse sentido, Vicente Paulo e Marcelo Alexandrino, ressaltam: 
As decisões do parlamento não podem ser de modo algum atacadas perante os tribunais; somente os atos praticados em decorrência de ato do parlamento é que podem ser examinados pelo Judiciário, a fim de verificar se não excederam os poderes conferidos ${ }^{35}$.

Nos sistemas de Constituição flexível vigora o princípio da supremacia material, indicando que determinados conteúdos são tipicamente constitucionais, e tais conteúdos devem ser observados pelo legislador ordinário.

Destarte, o controle de constitucionalidade existente, nos países de Constituição rígida, pressupõe que essa Constituição tenha caráter formal, sendo que suas normas são superiores às demais normas do ordenamento jurídico. $\mathrm{O}$ aspecto formal da Constituição escrita e rígida parte do princípio de que todas as normas contidas em seu interior são constitucionais e que as normas infraconstitucionais são inconstitucionais, quando estiverem em desacordo com seu conteúdo ou contenham vício de formalidade.

Vale destacar que a possibilidade de realização de controle de constitucionalidade das leis e atos normativos se dá, apenas, nos ordenamentos jurídicos que possuem uma Constituição rígida e escrita. Sob este prisma, é que afirma-se que as normas infraconstitucionais devem respeitar a Constituição.

As normas infraconstitucionais, para serem consideradas válidas dentro do ordenamento jurídico, devem estar de acordo com a Constituição e serem compatíveis com seu conteúdo, pois esta constitui-se na Lei Maior do sistema.

Por ser a Lei Maior de um ordenamento jurídico, a Constituição rígida está posicionada hierarquicamente acima das demais normas. Por estar na topo da pirâmide, segundo estabeleceu Kelsen, a Constituição é o parâmetro de elaboração das demais leis e atos normativos. As leis e atos normativos devem respeitar os princípios e regras constitucionais, além de, atender, de modo rigoroso, ao processo legislativo contido nela. As leis e atos normativos que contenham vício formal, no que toca ao procedimento de sua elaboração, ou material, cujo conteúdo seja contrário ao texto constitucional, acabam por serem declaradas nulas e inconstitucionais.

Além disso, o princípio da supremacia da Constituição exige que toda a construção jurídica de um Estado Democrático de Direito esteja em conformidade com

\footnotetext{
${ }^{35}$ PAULO, Vicente. ALEXANDRINHO, Marcelo. Controle de Constitucionalidade. 2004, p. 3.
} 
a Carta Magna, e a violação a esse preceito gera a inconstitucionalidade, sendo ela um conflito jurídico/político de lei ou ato normativo com a Carta Política.

Sobre a inconstitucionalidade, Vicente Paulo e Marcelo Alexandrino asseveram:

\footnotetext{
Inconstitucional é, pois, a ação ou omissão que ofende, no todo ou em parte, a Constituição. Se a lei ordinária, a lei complementar, o estatuto privado, o contrato, o ato administrativo etc. não se conformarem com a constituição, não devem produzir nenhum efeito. Ao contrário, devem ser fulminados, por inconstitucionais, com base no princípio da supremacia constitucional ${ }^{36}$.
}

A partir dessas considerações, em um Estado Democrático de Direito, vigora o princípio da presunção de legitimidade das leis, cujo alicerce está em declarar que toda norma jurídica presume-se legítima, isto é, constitucional. Este princípio estabelece-se para se promover segurança jurídica, sem a qual haveria desestruturação social e jurídica, se eventualmente as normas infraconstitucionais estivesses em conflito com a Constituição.

Outro aspecto importante é que, num Estado de Direito onde vigora o princípio da separação dos poderes, exige-se a instituição de um poder independente do Legislativo, para que seja realizado este controle de constitucionalidade das leis e atos normativos, a fim de assegurar a Supremacia da Constituição, o Poder Judiciário.

No caso brasileiro, por exemplo, a própria Constituição Federal estabelece que o Supremo Tribunal Federal é o órgão responsável pelo controle de constitucionalidade das leis e atos normativos elaborados pelos demais poderes da República. Ao STF cabe analisar e decidir se houve ofensa ou não à Constituição, e, dependendo do caso, haverá a anulação do ato constatado como inconstitucional.

Indubitavelmente, o controle de constitucionalidade decorre do constitucionalismo e, presume a existência de uma Constituição, ou de conjuntos normativos que disciplinam sobre a vida social, política e econômica de um país. O controle de constitucionalidade pode ser difuso ou concentrado. Far-se-á uma análise modesta dos institutos.

Sobre o controle de constitucionalidade difuso, destaca-se que essa modalidade surgiu nos Estados Unidos em meados de 1.803, no caso conhecido como Marbury vs.

\footnotetext{
${ }^{36}$ PAULO, Vicente. ALEXANDRINO, Vicente. Op. cit. p.4.
} 
Madison, julgado por John Marshal, que basicamente decidiu sobre a legitimidade da diplomação de Marbury, por ter sido indicado para o cargo de juiz, bem como sobre a constitucionalidade da nova lei de organização do Poder Judiciário, conhecida como Judiciary Act of 1801. Muito embora o objeto da ação não tenha sido especificamente o de declaração de (in) constitucionalidade, o caso concreto, por fim, permitiu que o controle fosse feito. O controle difuso consiste, portanto, no reconhecimento de inconstitucionalidade de um ato normativo por qualquer membro do Judiciário, juiz ou tribunal, diante de um caso concreto submetido à sua prestação jurisdicional ${ }^{37}$.

Sobre o controle de Constitucionalidade, Sara Maria Stroher Paes disserta:

A origem do atual sistema de controle de constitucionalidade foi criação dos Estados Unidos da América, país que, pela sua própria formação, revestido foi de forte tradição democrática onde a interpretação da Lei Maior configurou-se fonte orientadora de todas as relações jurídicas da sociedade. $\mathrm{O}$ Judicial Review, do Direito americano, não proveio de texto expresso da Constituição; foi uma criação da jurisprudência. Embora discutido pelos elaboradores da Constituição, não o inseriram no texto Constitucional entre as atribuições da Corte Supremo como um meio de garantia contra os excessos do Legislativo ou do Executivo. Sendo certo que foi o famoso caso Marbury vs. Madison, que deu origem à jurisprudência construída pela Suprema Corte dos Estados Unidos, onde, em 1803, o juiz John Marshall expôs limpidamente sua doutrina de competência do judiciário para apreciar a conformidade das leis com a Suprema $\mathrm{Carta}^{38}$.

O controle concentrado ou abstrato de constitucionalidade encontra inspiração na Constituição da Áustria de 1920, que fora elaborada por Hans Kelsen. Tal Constituição foi pioneira na previsão de um tribunal que tivesse como função primordial a jurisdição constitucional.

Hans Kelsen é o principal representante da escola normativista do direito, vertente do positivismo. Sob a influência de Kelsen, a Constituição da Áustria de 1920 introduziu em seu bojo o controle concentrado de constitucionalidade das leis e atos normativos como função jurisdicional de uma jurisdição constitucional, cabendo-lhe a estrita função de defesa e proteção das normas constitucionais.

Sobre o controle de constitucionalidade Kelsen disserta:

\footnotetext{
${ }^{37}$ COLARES, Maria Lucia Fialho. Jurisdição Constitucional. 1996, p.140.

${ }^{38}$ PAES, Sara Maria Ströher. Sistema brasileiro de controle da constitucionalidade: origem e evolução. 1993, P. 141.
} 
Devem ser submetidos ao controle da jurisdição constitucional todos os atos em forma de lei, inclusive os que só contêm normas individuais e, por exemplo, o orçamento e todos aqueles que, por alguma razão, tendem a ser vistos como meros atos administrativos pela doutrina tradicional, a despeito de terem forma de lei. $\mathrm{O}$ controle de sua regularidade não pode ser entregue a qualquer outra instância que não a jurisdição constitucional. Essa deve dispor do poder de verificar, inclusive, outros atos do Parlamento que, sem terem necessariamente forma de lei - não sendo exigida sua publicação no Diário Oficial -, têm caráter obrigatório nos termos da Constituição, por exemplo, o regimento interno do Parlamento, a matéria orçamentária (se essa não for aprovada em forma de lei) e outros atos semelhantes ${ }^{39}$.

O controle concentrado consiste, portanto, no mecanismo capaz de exterminar do ordenamento jurídico uma lei ou ato que sejam contrários a Constituição. O exercício desse controle está desvinculado de um caso concreto. O controle é exercido especificamente para se constatar a validade ou adequação de uma lei em face da Constituição. O objeto da ação é necessariamente a verificação de conformidade e adequação com a Constituição.

\subsection{Considerações Sobre as Origens do Controle de Constitucionalidade no Brasil}

$\mathrm{Na}$ presente exposição, vale contextualizar a história do controle de constitucionalidade no Brasil e de como se deu sua operacionalização no sistema jurídico.

A Constituição de 1824 não previa qualquer forma de controle de constitucionalidade. Inspirada pela concepção francesa de separação de poderes, a Constituição do Império previu que ao Legislativo caberia fazer as leis, interpretá-las, suspendê-las e revoga-las e velar na guarda da Constituição. ${ }^{40} \mathrm{O}$ Controle era, portanto, político.

Sobre o tema, Gilmar Ferreira Mendes assevera que:

\footnotetext{
${ }^{39}$ KELSEN, Hans. A Garantia Jurisdicional da Constituição (A Justiça Constitucional). 2003, p. 111.

${ }^{40}$ Art. 15. E' da attribuição da Assembléa Geral: VIII. Fazer Leis, interpretal-as, suspendel-as, e rovogalas; IX.Velar na guarda da Constituição, e promover o bem geral do Nação. Disponível em http://www.planalto.gov.br/ccivil_03/Constituicao/Constituicao24.htm acesso em 07.10.19
} 
A Constituição de 1824 não contemplava qualquer sistema assemelhado aos modelos hodiernos de controle de constitucionalidade. A influencia francesa ensejou que se outorgasse ao Poder Legislativo a atribuição de "fazer leis, interpretá-las, suspendê-las e revogá-las" bem como "velar na guarda da Constituição" (art. 15, n ${ }^{\circ} 8^{\circ}$ e $\left.9^{\circ}\right)^{41}$.

A Constituição de 1891, influenciada pelo modelo americano, passou a prever o controle difuso de constitucionalidade. A competência de controle difuso é outorgada ao Judiciário. O sistema abrangia todos os tribunais do País, nas esferas estadual e federal. A declaração de inconstitucionalidade se dava de modo incidental e seus efeitos eram refletidos apenas no caso concreto, não deixando de existir no ordenamento jurídico.

Sara Maria Stroher Paes entende que:

O controle de constitucionalidade é um dos princípios decorrentes do constitucionalismo, ao lado de outros pressupostos: supremacia da Constituição e hierarquia das leis. Atualmente não se pode falar em controle sem presumir-se a existência de uma Constituição, ou de um conjunto normativo, a disciplinar sobre a vida econômica, política e social de uma nação ${ }^{42}$.

A Constituição de 1934, criou novos mecanismos de atuação do Poder Judiciário. Criou a reserva de plenário, pela qual, somente por meio da maioria absoluta dos membros dos Tribunais, possuem competência para declarar a inconstitucionalidade das leis e atos normativos. O Senado Federal adquiriu atribuição para suspender a execução de uma lei declarada inconstitucional pelo Poder Judiciário num caso concreto.

Sobre o texto constitucional de 1934 e o controle de constitucionalidade, Gilmar Ferreira Mendes assevera que:

Talvez a mais fecunda e inovadora alteração introduzida pelo texto magno de 1934 se refira à "declaração de inconstitucionalidade para evitar a intervenção federal", tal como a denominou Bandeira de Mello, isto é, a representação interventiva, confiada ao Procurador Geral da República, nas

\footnotetext{
41 MENDES, Gilmar Ferreira. A evolução do direito constitucional brasileiro e o controle de constitucionalidade da lei. 1995, p.87.

${ }^{42}$ PAES, Sara Maria Ströher. Sistema brasileiro de controle da constitucionalidade : origem e evolução. 1993, p. 140.
} 
hipóteses de ofensa aos princípios consagrados no art. 7, I, $a$ a $h$, da Constituição ${ }^{43}$.

Na Constituição de 1937 o controle de constitucionalidade sofreu retrocesso significativo, apesar de a Carta ainda prever o controle difuso. O Presidente da República poderia submeter ao congresso a lei declarada inconstitucional pelo Judiciário. A decisão do parlamento, em reconhecer a constitucionalidade da norma, sobrepujaria a decisão do Judiciário.

A saber, na Constituição de 1946 retornam as disposições suprimidas pela Constituição de 1937. O controle difuso volta a ser exercido exclusivamente pelo Judiciário. A competência do Senado foi reestabelecida para suspender a execução de lei declarada inconstitucional pelo STF. O Procurador Geral da República detém a legitimidade para realizar pedido de inconstitucionalidade perante o STF.

Surge então a $E C \mathrm{n}^{\circ} 16 / 65$, com esta emenda, foi introduzido no ordenamento jurídico brasileiro, o controle abstrato de normas. O STF adquiriu competência para julgar a ação direta de inconstitucionalidade, tendo como legitimado exclusivo o Procurador Geral da República.

Já a Constituição de 1967/1969 não trouxe maiores inovações. Manteve o controle difuso e abstrato de normas. A jurisprudência do STF nesse período sedimentou a natureza jurídico-processual do processo do controle abstrato de normas, tendo como escopo a natureza objetiva do processo, a iniciativa do PGR para provocar o Judiciário, bem como o reconhecimento da eficácia erga omnes das decisões de mérito.

Nesse sentido, Edylcéa Tavares Nogueira de Paula salienta:

Em nosso País, o controle se exerce real e efetivamente pelo sistema misto, na acepção do conceito, eis que se pode dar incidentalmente, no caso concreto, por todos os juízes (difuso), e através da ação direta de declaração de inconstitucionalidade da lei em tese (concentrado). Nenhum outro Estado contemporâneo chegou a este tipo de controle da lei em abstrato, que somente existe no Brasil ${ }^{44}$.

$\mathrm{Na}$ Constituição de 1988, os controles difuso e abstrato das normas foram mantidos, todavia trouxe inovações conferindo ampla legitimidade na ação direta de

\footnotetext{
${ }^{43}$ MENDES, Gilmar Ferreira. Op. cit. 1995, p.90.

${ }^{44}$ PAULA, Edylcéa Tavares Nogueira de. Do controle de constitucionalidade das leis. Sistemas de controle. 1982, p. 100.
} 
inconstitucionalidade, criou a ADI por omissão, a ADC e ADPF, o mandado de injunção e conferiu aos estados a competência para fazer o controle abstrato de normas $^{45}$.

A Carta de 1988, certamente foi a que maior significância trouxe para o controle de constitucionalidade. A princípio, tirando da seara exclusiva de propositura da ação de inconstitucionalidade do Procurador Geral da República, ampliando o rol de legitimados em seu artigo $103^{46}$.

Sobre a ampliação do rol de legitimados, Gilmar Ferreira Mendes aponta que:

(...) a ampla legitimação conferida ao controle conferida ao controle abstrato,
com a inevitável possibilidade de se submeter qualquer questão
constitucional ao Supremo Tribunal Federal, operou uma mudança
substancial - ainda que não desejada - no modelo de controle de
constitucionalidade até então vigente no Brasil ${ }^{47}$.

O Brasil adotou os dois modelos de controle de constitucionalidade, o difuso, cuja origem é norte americana, e o concentrado de origem europeia.

Vale destacar que instituto do controle de constitucionalidade no período pós Constituição Federal de 1988, foi ampliado e aperfeiçoado. Como visto, o Brasil aderiu ao sistema norte americano de controle de constitucionalidade, o judicial difuso, transitando para um sistema peculiar misto, unindo o modelo difuso, por via incidental com o concentrado, por meio da ação direta.

Em sua evolução, o controle de constitucionalidade foi ampliado com a criação da Ação Declaratória de Constitucionalidade (ADC), criada pela Emenda Constitucional $n^{o} 3$ de 1993. Essa ação pode ser ajuizada diretamente no Supremo Tribunal Federal, a fim de obter a declaração de constitucionalidade de uma lei ou ato normativo federal, ante uma controvérsia judicial acerca de sua validade.

\footnotetext{
45 Tribunais de Justiça podem exercer controle abstrato de constitucionalidade de leis municipais utilizando como parâmetro normas da Constituição Federal, desde que se trate de normas de reprodução obrigatória pelos Estados (STF, RE 650898/RS, Info 852).

46 Art. 103. Podem propor a ação direta de inconstitucionalidade e a ação declaratória de constitucionalidade: I - o Presidente da República; II - a Mesa do Senado Federal; III - a Mesa da Câmara dos Deputados; IV a Mesa de Assembléia Legislativa ou da Câmara Legislativa do Distrito Federal; V o Governador de Estado ou do Distrito Federal; VI - o Procurador-Geral da República; VII - o Conselho Federal da Ordem dos Advogados do Brasil; VIII - partido político com representação no Congresso Nacional; IX - confederação sindical ou entidade de classe de âmbito nacional. Disponível em http://www.planalto.gov.br/ccivil_03/constituicao/constituicaocompilado.htm acesso em 07.10.19.

${ }^{47}$ MENDES, Gilmar Ferreira. Op. cit. 1995, p. 98.
} 
Por conseguinte, a Constituição Federal de 1988 previu em seu bojo que os Estados possuem a prerrogativa de realizarem o controle de constitucionalidade de leis ou atos normativos estaduais ou municipais em face da Constituição Estadual (CF

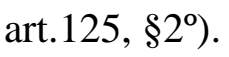

As ações direta de inconstitucionalidade e declaratória de constitucionalidade possuem previsão constitucional (CF art. 102, I, “a”), e são reguladas pela lei 9.868/99, que dispõe sobre o processo e julgamento delas perante o Supremo Tribunal Federal. O objeto delas é a lei ou ato normativo, seja ele federal ou estadual. As decisões definitivas de mérito nas referidas ações, produzirão efeito contra todos e efeito vinculante relativamente aos demais órgãos do Poder Judiciário e à administração pública direta e indireta, nas esferas federal, estadual e municipal ( $\mathrm{CF}$ art. 10, $\S 2^{\circ}$ ).

Outro mecanismo previsto na Carta Magna de 88 é a Arguição de Descumprimento de Preceito Fundamental (ADPF), cuja disposição encontra-se disciplinada no art. $102, \S 1^{\circ}$ da $\mathrm{CF}$, e regulamentada pela lei $9.882 / 99$, que prevê o processo e julgamento dessa ação. A ADPF ampliou o sistema de controle de constitucionalidade, passando a incorporar matérias que não eram atendidas pela ADI e ADECON.

A exemplo disso destaca-se que a ADPF possibilitou a impugnação de atos normativos municipais em face da Constituição Federal, e ainda, quando houver litígio envolvendo direito pré-constitucional. Outro aspecto relevante, é que a ADPF não se limita a apreciação de atos normativos, podendo, por meio dela, serem impugnados quaisquer atos do Poder Público dos quais resulte lesão ao ameaça a preceito fundamental da Constituição da República (art. $1^{\circ}$, parágrafo único, I da Lei 9.882/99).

Entrementes, a Constituição Federal de 1988 inovou ao estabelecer a Ação Direta de Inconstitucionalidade por Omissão (ADO), cujo objetivo é o de tornar efetiva norma constitucional. Algumas normas constitucionais possuem eficácia limitada e, habitualmente, estão destituídas de efetividade, por tal razão se justifica o ajuizamento da ADO. Salienta-se que a Ação Direta de Constitucionalidade por Omissão do Brasil, se inspirou na Constituição da República Portuguesa ${ }^{48}$.

\footnotetext{
${ }^{48}$ Artigo $2833^{\circ}$ Inconstitucionalidade por omissão 1. A requerimento do Presidente da República, do Provedor de Justiça ou, com fundamento em violação de direitos das regiões autónomas, dos presidentes das Assembleias Legislativas das regiões autónomas, o Tribunal Constitucional aprecia e verifica o não cumprimento da Constituição por omissão das medidas legislativas necessárias para tornar exequíveis as normas constitucionais.2. Quando o Tribunal Constitucional verificar a existência de inconstitucionalidade por omissão, dará disso conhecimento ao órgão legislativo competente. Disponível
} 
Ao ser declarada a inconstitucionalidade por omissão, será dada ciência ao Poder competente para a adoção das providências necessárias e, em se tratando de órgão administrativo, para fazê-lo em trinta dias (CF art. 103, $\left.\S 2^{\circ}\right)$. Vale destacar a edição da lei 12.063/2009, que estabeleceu a disciplina processual da ADO na lei 9.868/99, que trata do processo e julgamento da ação direta de inconstitucionalidade e da ação declaratória de inconstitucionalidade.

Outra medida demasiadamente relevante para o controle de constitucionalidade pátrio é a chamada Representação Interventiva Federal (ADI Interventiva) (CF 34, VII; 36, III) e disciplinada pela Lei 12.562/11 que regulamenta o inciso III do art. 36 da Constituição Federal, para dispor sobre o processo e julgamento da representação interventiva perante o Supremo Tribunal Federal. O Objeto da IF consiste em defender os princípios sensíveis, nos casos em que a lei ou ato normativo os viole, omissão ou incapacidade das autoridades locais assegurarem os princípios sensíveis, ato governamental estadual que desrespeite os princípios sensíveis da $\mathrm{CF}$, ato administrativo e concreto que viole os princípios sensíveis (Lei 12.562/11, art. $2^{\circ}$ ). Os princípios sensíveis são os previstos no art. 34, VII da CF.

Uma importante inovação no sistema judicial pátrio é a possibilidade de o Supremo Tribunal Federal editar Súmulas com caráter vinculante. Tal instituto foi incluído na Constituição de 88 por meio da Emenda Constitucional no 45/2004, que acrescentou ao texto constitucional o artigo 103-A.

O Supremo Tribunal Federal poderá de ofício ou por provocação, mediante decisão de dois terços dos seus membros, depois de reiteradas decisões sobre matéria constitucional, aprovar súmula que, a partir de sua publicação na imprensa oficial, terá efeito vinculante em relação aos demais órgãos do Poder Judiciário e à administração pública direta e indireta, nas esferas federal, estadual e municipal, bem como proceder à sua revisão ou cancelamento, na forma estabelecida em lei (CF art. 103-A).

O objetivo da súmula consiste na validade, a interpretação e a eficácia de normas determinadas, acerca das quais haja controvérsia atual entre órgãos judiciários ou entre esses e a administração pública que acarrete grave insegurança jurídica e relevante multiplicação de processos sobre questão idêntica (CF art.103-A, §1º).

Ademais, os legitimados da ADI podem provocar a aprovação, revisão ou cancelamento da súmula. A contrariedade da súmula por ato administrativo ou decisão 
judicial, acarretará na possibilidade de reclamação ao Supremo Tribunal Federal, que poderá anular o ato administrativo ou cassar a decisão judicial, caso seja julgada procedente (CF art. 103-A, $\S \S 2^{\circ}$ e $\left.3^{\circ}\right)$.

\subsection{Perspectivas do Ativismo Judicial como Práticas Comuns do Supremo Tribunal Federal}

Antes de abordar acerca do ativismo judicial, é importante destacar sobre os efeitos nos pronunciamentos e seus diferentes reflexos nos diversos sistemas de constitucionalidade das leis.

Sob este prisma, Iacyr de Aguiar Vieira dispõe:

\footnotetext{
Para uma abordagem eficaz dos efeitos dos pronunciamentos nos diferentes sistemas de controle da constitucionalidade das leis, há que se analisar, primeiramente, o conteúdo das decisões que são proferidas em cada sistema por meio dos modos específicos com que a questão da constitucionalidade é interposta. Nos ordenamentos jurídicos estudados, apresentam-se dois modelos básicos de controle da constitucionalidade: o controle político e o controle jurisdicional $^{49}$.
}

A princípio ressalta-se o controle político, que, por sua vez, é uma forma de se verificar previamente a constitucionalidade dos atos normativos apresentados ao órgão competente, esperando um pronunciamento a respeito. Sob esta perspectiva, está presente o instituto do controle preventivo, pois, impede a entrada em vigor de determinada norma que não esteja compatível com a Constituição.

No que toca ao ativismo judicial, alguns defendem que estamos vivendo numa "supremocracia", cujo conceito aponta o papel do STF como aquele que está no centro do atual sistema político, tendo por certo que este fenômeno, representaria em tese, a fragilidade do sistema representativo. Nesse aspecto, estar-se-ia diante de um governo do Supremo Tribunal Federal.

\footnotetext{
${ }^{49}$ VIEIRA, Iacyr de Aguilar. O controle de constitucionalidade das leis e os diferentes sistemas. 1999, p.50.
} 
Para Oscar Vilhena Vieira ${ }^{50}$, o Supremo Tribunal Federal, quando atua com ativismo, está exercendo função legislativa, cirando regras novas e sugando a atribuição de intérprete da constituição, incorporando, então, as atribuições do Poder Legislativo.

Neste mesmo sentido, uma corte constitucional jamais é percebida como elemento natural da democracia. $\mathrm{O}$ ativismo judicial se justificaria na medida em, muito embora o parlamento seja indispensável ao exercício democrático, ele se revela insuficiente. A atuação do Supremo Tribunal Federal em relação ao Poder Legislativo tem o condão de não supressão de sua atuação, mas de relativizar seu papel.

É provável que essa atuação do Supremo Tribunal Federal esteja estritamente ligada as transformações sociais no que tange a globalização, como também do ponto de vista da mutação e ampliação dos direitos humanos. Norberto Bobbio numa entrevista assinalou:

\footnotetext{
Não faz muito tempo, um entrevistador, após uma longa conversa sobre as características de nosso tempo que despertam viva preocupação para o futuro da humanidade, sobretudo três, o aumento cada vez maior e até agora incontrolado da população, o aumento cada vez mais rápido e até agora da degradação do meio ambiente, o aumento cada vez mais rápido, incontrolado e insensato do poder destrutivo dos armamentos, perguntou-me ao final, se, em meio a tantas previsíveis causas de infelicidade, eu via algum sinal positivo. Respondi que sim, que via pelo menos um desses sinais: a crescente importância atribuída, nos debates internacionais, entre homens de cultura e políticos, em seminários de estudo em conferências governamentais, ao problema do reconhecimento dos direitos do homem ${ }^{51}$.
}

O ativismo judicial também encontra guarida na ausência representativa do Poder Legislativo. O modelo de representação popular por meio do voto direto não é a única forma de representação popular. Essa ausência se justifica quando os parlamentares eleitos não atuam de modo a representar os interesses da sociedade de um modo geral, ou seja, geralmente os parlamentares eleitos representam determinado grupo ou determinada categoria, que, sucessivamente, são minoritárias.

De acordo com um dado da agência Brasil, de Luiza Damé, empresários e profissionais liberais são maioria na câmara. Em média 2/3 dos eleitos e reeleitos são empresários e profissionais liberais, sendo que os demais estão entre assalariados e

\footnotetext{
${ }^{50}$ VIEIRA, Oscar Vilhena. Supremocracia. 2008. p. 440.

${ }^{51}$ BOBBIO, Norberto. A era dos direitos. 1992, p.49.
} 
profissionais de atividades diversas, como ator, humorista, sacerdotes e pastor evangélico e estudantes ${ }^{52}$.

Com esse dado, parece que um sinal de alerta aparecerá nesse novo período legislativo. Nota-se a crise de representatividade no Poder Legislativo em prol da sociedade de um modo geral, sobre questões que envolvam saúde, segurança, educação, trabalho, por isso é que os fenômenos do ativismo judicial e da judicialização das políticas públicas estão sendo cada vez mais potencializados.

Sobretudo, verifica-se que essas formas de atuação do Supremo Tribunal Federal, se justificam na inércia ou omissão do Poder Público, para a garantia e efetivação dos direitos fundamentais, razão pela qual o ativismo judicial, tornou-se uma prática comum nas decisões da Corte Constitucional brasileira.

A expressão "ativismo judicial", não encontra consenso entre os estudiosos desse fenômeno no Brasil. Acerca do tema, Paulo Gustavo Gonet Branco entende:

\begin{abstract}
As referências ao que se tem designado como ativismo judicial refletem outro caso de expressão utilizada sem maiores cuidados com a definição dos seus contornos. Nem mesmo se encontra um consenso em torno de saber se refere a uma atitude desejável ou negativa. O risco disso está em tornar a expressão inútil por superabrangente, ou, ainda pior, transformá-la num daquelas armadilhas semânticas que enredam os participantes desavisados do debate público, fazendo-os supor verdades ainda não estabelecidas e a julgar instituições e a formar opiniões políticas sobre bases dissolventes da mistificação ${ }^{53}$.
\end{abstract}

Como todo pensamento e como todo conceito existem variações e noções diversas, no ativismo judicial não é diferente, ou seja, não é dotado de unanimidade. O ativismo judicial está eivado, muitas vezes, de aspectos ideológicos e paixões políticas, bem como há críticas, que são utilizadas como ferramenta de combate aos posicionamentos favoráveis à prática.

Entretanto, a expressão ativismo judicial contém, para alguns, aspectos positivos, que contestam a critica em relação ao tema, haja vista que o ativismo, em

\footnotetext{
52 Damé, Luiza. Empresários e profissionais liberais são maioria na nova Câmara - Repórter da Agência Brasil Brasília. Publicado em 12.10.2018. Disponível em http://agenciabrasil.ebc.com.br/politica/noticia/2018-10/empresarios-e-profissionais-liberais-sao-maioriana-nova-camara. Acesso em 07.10.19.

${ }^{53}$ BRANCO, Paulo Gustavo Gonet. Em busca de um conceito fugidio - o ativismo judicial. Texto não publicado, 2011, p.2 - Extraído da dissertação de mestrado de Carolina Scherer Bicca, intitulada "Ativismo Judicial" no Controle das Políticas Públicas: O caso da Assistência Social no Brasil.
} 
certa medida, contribui para a concretização das normas constitucionais e, acima de tudo, dos direitos e garantias fundamentais. Nessa perspectiva, é importante destacar a disposição de Mayra Martinho Miarelli e Rogério Montai de Lima, que dissertam:

\begin{abstract}
Por "ativismo judicial" entende-se o papel criativo dos tribunais ao fazerem uma contribuição nova para o direito, decidindo sobre a singularidade ao caso concreto, formando o precedente jurisprudencial, antecipando-se, muitas vezes, à formulação da própria lei. Diante da necessidade que forjam uma determinada interpretação, do texto de lei, é o momento em que o esforço do interprete faz-se sentir. Tem-se como ativismo judicial, portanto, a energia emanada dos tribunais no processo da criação do direito ${ }^{54}$.
\end{abstract}

Na concepção de Montesquieu, de que o Poder Judiciário é apenas a boca da lei, tema que será abordado mais adiante, quando se fala em ativismo judicial, este conceito cai por terra. A ideia de que o juiz deve expressar apenas o que está contido no texto frio da lei, não encontra espaço quando se tem a prática do ativismo judicial. No ambito do ativismo, o juiz como aquele que concretiza o direito ao caso concreto, terá a liberdade consciente, dentro dos limites estabelecidos e respeitando a segurança jurídica, de criar interpretações jurisprudenciais, a fim de se garantidor dos direitos constitucionais expressos na Carta Magna.

Sob o aspecto conceitual de ativismo judicial, Elival da Silva Ramos assevera:

O exercício da função jurisdicional para além dos limites impostos pelo próprio ordenamento que incumbe, institucionalmente, ao Poder Judiciário fazer atuar, resolvendo litígios de feições subjetivas (conflitos de interesses) e controvérsias jurídicas de natureza objetiva (conflitos normativos) ${ }^{55}$.

Elival da Silva Ramos, diferentemente daqueles que entendem ser o ativismo judicial uma prática positiva, entende o oposto, apontando que a exacerbação dos limites institucionais e as atividades judicantes na interpretação das normas, contém caráter estritamente subjetivo.

\footnotetext{
54 MIARELLI, Mayra Marinho. Ativismo Judicial e a efetivação de direitos no Supremo Tribunal Federal. 2012, p.16.

${ }^{55}$ RAMOS, Elival da Silva. Ativismo Judicial: Parâmetros Dogmáticos. 2010, p.219
} 
De fato, quando o Poder Judiciário, segundo ele, vai além de suas funções típicas, está agredindo violentamente o principio da separação dos poderes, e ainda, nas decisões judiciais em se criam novas normas, há interferência direta na atuação do Poder Executivo quanto às políticas públicas. Diante dessa atuação, deve haver olhares atentos e imensa preocupação, sendo, portanto, o ativismo judicial um fator de violação à segurança jurídica.

Para os entusiastas do ativismo judicial, como Luís Roberto Barroso, a expressão não está vinculada ao uso indevido do poder, todavia representa uma extensão participativa, na busca da implementação mais profunda das disposições constitucionais. A noção de ativismo judicial é a de se colocar nos espaços onde a atuação do Poder Legislativo é ausente ou omissa.

É importante asseverar que a Constituição Federal de 1988 possui valor axiológico demasiadamente elevado, por essa razão, dificultar a concretização das suas disposições expressas, ocasionará na violação dos direitos e garantias fundamentais, ferindo diretamente o conteúdo constitucional. Além disso, a postura omissa do Poder Legislativo num Estado Democrático de Direito, faz com que valores fundamentais sejam afetados.

Decerto, a postura filáucia do Judiciário quando se comporta de maneira aparentemente exagerada, consiste elementarmente em garantir que os valores constitucionais sejam efetivamente concretizados. A atuação do STF torna-se mais presente, a fim de que os alicerces do Estado Democrático de Direito sejam sustentados, destacando-se que o objetivo é o de que os anseios do poder constituinte originário sejam alcançados.

Seguindo esse entendimento, Luís Roberto Barroso confirma:

\footnotetext{
A ideia de ativismo judicial está associada a uma particpação mais ampla e intensa do Judiciário na concretização dos valores e fins constitucionais, com maior interferência no espaço de atuação dos outros dois Poderes. Em muitas situações, sequer há confronto, mas mera ocupação de espaços vazios. [...] o ativismo é uma atitude de um modo específico e proativo de interpretar a Constituição, expandindo o seu sentido e alcance [...] o ativismo judicial legitimamente exercido procura extrair o máximo das potencialidades construindo regras específicas da condita de enunciados vagos $[\ldots]^{56}$.
}

\footnotetext{
${ }^{56}$ BARROSO, Luís Roberto. O Controle de Constitucionalidade no Direito Brasileiro. 2011, p.365-366.
} 
O ativismo judicial, segundo Luís Roberto Barro, é uma medida excepcional de atuação do Poder Judiciário, de modo que seu exercício implica numa solução transitória para a crise institucional estabelecida nos demais poderes da nação. Nesse sentido, ele disserta:

\begin{abstract}
Uma nota final: o ativismo, até aqui, tem sido parte da solução e não do problema. Mas ele é um antibiótico poderoso, cujo uso deve ser eventual e controlado. Em dose excessiva, há risco de se morrer da cura. A expansão do Judiciário não deve desviar a atenção da real disfunção que aflige a democracia brasileira: a crise de representatividade, legitimidade e funcionalidade do poder legislativo ${ }^{57}$.
\end{abstract}

Faz-se necessário destacar algumas, das várias decisões como exemplos concretos de atuação ativista do Supremo Tribunal Federal, quais sejam: Interrupção da gestação de fetos anencefálicos - ADPF 54/DF ${ }^{58}$, cuja ementa diz:

\footnotetext{
FETO ANENCÉFALO - INTERRUPÇÃO DA GRAVIDEZ - MULHER LIBERDADE SEXUAL E REPRODUTIVA - SAÚDE -DIGNIDADE AUTODETERMINAÇÃO - DIREITOS FUNDAMENTAIS - CRIME INEXISTÊNCIA. Mostra-se inconstitucional interpretação de a interrupção da gravidez de feto anencéfalo ser conduta tipificada nos artigos 124, 126 e 128, incisos I e II, do Código Penal.
}

O Supremo Tribunal Federal julgou procedente o pedido da ADPF para declarar a inconstitucionalidade de interpretação segundo a qual a interrupção da gravidez de feto anencéfalo é conduta tipificada nos artigos 124, 126 e 128, incisos I e II, todos do Código Penal, isto é, nessa hipótese não há configuração do crime de aborto, pois no caso em tela a expectativa de vida extra-uterina desses fetos estaria comprometida, em razão de que, para se configurar aborto, deveria se presumir a possibilidade de continuação de vida do feto.

\footnotetext{
${ }^{57}$ BARROSO, Luís Roberto. Ano do STF: Judicialização, ativismo e legitimidade democrática. apud MIARELLI, Mayra Marinho. Ativismo Judicial e a efetivação de direitos no Supremo Tribunal Federal. 2012, p.173.

${ }^{58}$ Supremo Tribunal Federal. ADPF n. 54/DF. Relatoria do Ministro Marco Aurélio. Julgamento 12.04.2012
} 
Os fundamentos constitucionais para a procedência dessa ação estão nos $\operatorname{artigos} 1^{\circ}$, IV - dignidade da pessoa humana,$- 5^{\circ}$, II - princípio da legalidade, liberdade e autonomia da vontade -, $6^{\circ}$, caput, e 196 - direito à saúde.

Decerto, caberia ao Poder Legislativo decidir a matéria por via legislativa estabelecendo uma exceção para esses casos, já que tal conduta seria criminalizada pelo Código Penal. Tendo em vista uma Câmara dos Deputados demasiadamente conservadora, não se encontraria espaço para essa hipótese como exceção, já que para muitos religiosos qualquer forma de vida deve ser respeitada.

Embora entidades religiosas e afins tivessem opinado nessa questão, prevaleceu o entendimento da laicidade do Estado sendo que suas leis não devem estar subordinadas a critérios meramente religiosos.

Outra decisão relevante e que demonstra ativismo judicial é o do reconhecimento da união estável e casamento homoafetivos contidos na ADI $4277^{59}$,ADPF $132^{60}$ e na Resolução 175 do Conselho Nacional de Justiça ${ }^{61}$, cuja ementa destacamos:

ARGUIÇÃO DE DESCUMPRIMENTO DE PRECEITO FUNDAMENTAL (ADPF). PERDA PARCIAL DE OBJETO. RECEBIMENTO, NA PARTE REMANESCENTE, COMO AÇÃO DIRETA DE INCONSTITUCIONALIDADE. UNIÃO HOMOAFETIVA E SEU RECONHECIMENTO COMO INSTITUTO JURÍDICO. CONVERGÊNCIA DE OBJETOS ENTRE AÇÕES DE NATUREZA ABSTRATA. JULGAMENTO CONJUNTO. Encampação dos fundamentos da ADPF $n^{\circ}$ 132-RJ pela ADI $n^{\circ}$ 4.277-DF, com a finalidade de conferir "interpretação conforme à Constituição" ao art. 1.723 do Código Civil. Atendimento das condições da ação.

A união homoafetiva foi considerada entidade familiar, se revestindo do mesmo direito que a união estável heterossexual possui, desde que preenchidos os requisitos estabelecidos em lei para sua configuração.

Prevaleceu o voto do relator Ministro Ayres Britto, que deu interpretação conforme a Constituição Federal ao art. 1.723 do Código Civil para dele excluir

\footnotetext{
${ }^{59}$ Supremo Tribunal Federal. ADI n. 4277/DF. Relatoria do Ministro Ayres Britto. Julgamento 14.10.2011

${ }^{60}$ Supremo Tribunal Federal. ADPF n. 132/RJ. Relatoria do Ministro Ayres Britto. Julgamento 05.05.2011

${ }^{61}$ Disponível em https://atos.cnj.jus.br/atos/detalhar/1754
} 
qualquer significado que impeça o reconhecimento da união contínua, pública e duradoura entre pessoas do mesmo sexo como entidade familiar, entendida esta como sinônimo perfeito de família.

O relator ainda destacou que há um silêncio constitucional sobre o tema e asseverou que essa total ausência de previsão normativo-constitucional referente à fruição da preferência sexual possibilita a incidência da regra de que "tudo aquilo que não estiver juridicamente proibido, ou obrigado, está juridicamente permitido" (Constituição, artigo $5^{\circ}$, inciso II) e de que o emprego da sexualidade humana diz respeito à intimidade e à vida privada, as quais são direito da personalidade.

Dessa decisão decorreu a confecção da resolução 175 do Conselho Nacional de Justiça que possibilitou que pessoas do mesmo sexo contraíssem matrimônio civil, e ainda vedou às autoridades competentes a recusa de habilitação, celebração de casamento civil ou de conversão de união estável em casamento entre pessoas de mesmo sexo.

Um tema que vinha sendo debatido há muito tempo e que foi resolvido pelo STF foi a criminalização da homofobia na ADO $26^{62}$ e no Mandado de Injunção $4733^{63}$, cuja discussão se baseou na inércia legislativa do Congresso Nacional em editar lei para criminalizar todas as formas de homofobia e transfobia, nos termos do art. $5^{\circ}$, XLII, ou, subsidiariamente, da determinação contida no art. $5^{\circ}$, XLI, ou, por fim, do princípio da vedação da proteção deficiente, decorrente do art. $5^{\circ}$, LIV, todos da Constituição da República.

A decisão do Supremo Tribunal Federal julgou a ação procedente para a) reconhecer o estado de mora inconstitucional do Congresso Nacional na implementação da prestação legislativa destinada a cumprir o mandado de incriminação a que se referem os incisos XLI e XLII do art. $5^{\circ}$ da Constituição, para efeito de proteção penal aos integrantes do grupo LGBT; b) declarar, em consequência, a existência de omissão normativa inconstitucional do Poder Legislativo da União; c) cientificar o Congresso Nacional, para os fins e efeitos a que se refere o art. $103, \S 2^{\circ}$, da Constituição c/c o art. 12-H, caput, da Lei no 9.868/99; d) dar interpretação conforme à Constituição, em face dos mandados constitucionais de incriminação inscritos nos incisos XLI e XLII do art. $5^{\circ}$ da Carta Política, para enquadrar a homofobia e a transfobia, qualquer que seja a

${ }^{62}$ Supremo Tribunal Federal. ADO n. 26/DF. Relatoria do Ministro Celso de Mello. Julgamento 13.06.2019

${ }^{63}$ Supremo Tribunal Federal. MI n. 4733/DF. Relatoria do Ministro Edson Fachin. Julgamento 12.11.2018 
forma de sua manifestação, nos diversos tipos penais definidos na Lei $n^{\circ} 7.716 / 89$, até que sobrevenha legislação autônoma, editada pelo Congresso Nacional, seja por considerar-se, nos termos deste voto, que as práticas homotransfóbicas qualificam-se como espécies do gênero racismo, na dimensão de racismo social consagrada pelo entendimento jurisprudencial do STF.

Nessa decisão, a liberdade religiosa e de culto foram respeitadas, não estando sujeitas à conduta criminosa de homofobia, desde que suas ações não configurem discurso de ódio contra os grupos LGBT. O discurso de ódio é compreendido como exteriorizações que incitem a discriminação, a hostilidade ou a violência contra pessoas em razão de sua orientação sexual ou de sua identidade de gênero. Até que o Legislativo crie a norma, a criminalização da homofobia seguirá os ditames da lei 7.716 que define os crimes resultantes de preconceito de raça ou de cor.

Perda do mandato eletivo por infidelidade partidária na ADI $5081^{64}$, a ementa descreve:

DIREITO CONSTITUCIONAL E ELEITORAL. AÇÃODIRETA DE INCONSTITUCIONALIDADE. RESOLUÇÃO No 22.610/2007 DO TSE. INAPLICABILIDADE DA REGRA DE PERDA DOMANDATO POR INFIDELIDADE PARTIDÁRIA AO SISTEMA ELEITORAL MAJORITÁRIO.

Ante o anseio por uma reforma política no Brasil, verificou-se que parlamentares migravam de um partido para outros, fraudando, desta maneira, a vontade do eleitor, segundo o entendimento do STF. O Congresso Nacional não elaborava lei que limitava ou impedia essa prática. Diante disso o posicionamento do Poder Judiciário foi determinante para atender as demandas da sociedade.

O relator Ministro Roberto Barroso asseverou que:

(...) o pano de fundo o sistema proporcional, que é adotado para a eleição de deputados federais, estaduais e vereadores. As características do sistema proporcional, com sua ênfase nos votos obtidos pelos partidos, tornam a fidelidade partidária importante para garantir que as opções políticas feitas pelo eleitor no momento da eleição sejam minimamente preservadas. Daí a

\footnotetext{
64 Supremo Tribunal Federal. ADI n. 5081/DF. Relatoria do Ministro Roberto Barroso. Julgamento
} 27.05.2015 
legitimidade de se decretar a perda do mandato do candidato que abandona a legenda pela qual se elegeu.

A decisão não alcança os candidatos eleitos pelo sistema majoritário, sob pena de violação da soberania popular e das escolhas feitas pelo eleitor, pois caso houvesse possibilidade da perda de mandato, isso não constituiria num benefício para um partido político, pois nesse sistema, há uma conjuntura de partidos envolvidos no processo eleitoral.

Os exemplos não são poucos, e o ativismo é justificado pelos próprios ministros do Supremo Tribunal Federal que entendem ser a corte responsável por suprir as falhas dos órgãos representativos, garantindo que a sociedade possa alcançar proteção jurídica diante das omissões institucionais.

Sob este prisma, o ex-ministro do STF Cezar Peluso alerta:

O Supremo sempre aponta para os interesses gerais da sociedade. Essa acusação de ativismo não é exclusiva da Suprema Corte do Brasil. Nos EUA, sérios problemas que deveriam ter sido resolvidos no plano legislativo, ou na área administrativa, só tiveram solução social satisfatória com a intervenção da Suprema Corte. Foi assim inclusive com o racismo. No Brasil lidamos com uma Constituição Analítica, bem diferente da Americana, com seus poucos artigos. A nossa Carta cuida de uma série de matérias que poderia ser regidas por lei ordinária. E isso tem explicação: A Constituição de 88 foi editada após longo período de autoritarismo, quando, os constituintes resolveram regular tudo. Daí o Supremo ser acionado, ele decide. Isso já foi chamado de "ativismo judicial a convite constitucional", o que é apropriado. Só que o Supremo não dá motivos para acusações de partidarismo. Mesmo lidando com questões políticas, age com independência, ao contrário do que se ouve falar de outras cortes. Eu diria mais: quando decisões da corte chama a tenção da opinião pública é porque as matérias tratadas representam divisões dentro da sociedade brasileira. Falo de temas como o aborto, célulastronco, fetos anencéfalos, direitos homoafetivos.

É oportuno destacar que nos Estados Unidos da América, a expressão ativismo judicial aparece a primeira vez em um texto cujo título é "The Supreme Court: 1947, 
que fora publicado na revista Fortune em 1947, sendo redigido pelo jornalista Arthur Schlesinger $\mathrm{Jr}^{65}$.

Na leitura do Jornalista Arthr Schleisinger Jr., a Suprema Corte Americana era composta por dois tipos de juízes; o primeiro tipo era denominado por ele de "ativistas", que, na atribuições de suas funções judicantes, eram propensos a efetivar a justiça social, e o segundo de "auto contenção", que tinham uma postura mais conservadora em relação a legislação. O termo cunhado pelo jornalista foi rebatido por juristas, que acusaram Arthur de fazer ataques pessoais aos juízes da Suprema Corte.

Uma questão suscitada pelos estudiosos é sobre a origem do judicial review nos Estados Unidos. O debate em torno do tema discute se os pais fundadores tinham em mente a criação do instituto, pois a Constituição Americana não o prevê. Sobre o tema, Sérgio Antônio Ferreira Victor disserta:

\footnotetext{
A Constituição norte-americana não confere ao judiciário o poder de revisar a constitucionalidades das leis. Pelo menos não o faz expressamente. Dessa forma, deve-se procurar examinar os discursos proferidos pelos founding fathers durante os debates nas convenções que culminaram com a ratificação da Constituição para descobrir se eles tinham a intenção de atribuir esse poder ao judiciário, se eles não tinham essa intenção, ou se eles, pelo menos admitiram essa possibilidade ${ }^{66}$.
}

O debate não foi pacífico, tendo posições amplamente divergentes quanto a instituição do judicial review. Na prática, o tema foi resolvido envolvendo um caso concreto e emblemático que já fora mencionado neste trabalho, o Marbury v. Madison.

Pode afirmar-se que o exemplo americano foi drenado para o resto do mundo, dando origem ao controle de constitucionalidade que culmina no ativismo judicial e na judicialização das políticas públicas.

No Brasil, a justificação para o exercício do ativismo judicial baseia-se na concretização dos direitos e garantias fundamentais, bem como para suprir as deficiências de atuação dos poderes Executivo e Legislativo. Contudo, não se pode negar que, apesar dos aspectos positivos, o ativismo judicial deve ser utilizado

\footnotetext{
${ }^{65}$ Sobre a origem histórica da expressão Ativismo Judicial, recomendamos para um estudo aprofundado, a obra Ativismo ou Altivez? de Saul Tourinho Leal.

${ }^{66}$ VICTOR, Sérgio Antônio Ferreira. Diálogo institucional e controle de constitucionalidade. Debate entre o STF e o Congresso Nacional. 2015, p.76-77.
} 
excepcionalmente como modo de garantir equilíbrio na separação de poderes, e servir de função social do STF, suprindo omissões das demais esferas de poder. 


\section{SEPARAÇÃO DOS PODERES E O SUPREMO TRIBUNAL FEDERAL}

Neste capítulo veremos que há um embate crescente entre as instituições políticas brasileiras. Supremo Tribunal Federal e Congresso Nacional tornam-se protagonistas de verdadeiros conflitos de interesses. Decisões judiciais passam a influenciar de modo direto, quase que em todas as relações sociais. O Congresso Nacional, órgão de caráter representativo da nação, termina por tentar superar as decisões judiciais com a edição de leis, e isso por certo, gera insegurança, tanto jurídica quanto política. O diálogo institucional esbarra na frase: quem dá a última palavra? Veremos qual é o papel dos poderes na construção conjunta de soluções constitucionais.

O Supremo Tribunal Federal se vale do fenômeno do ativismo judicial para resolver questões de repercussão geral nacional, quando há inércia do poder público ou omissão legislativa. Essa atuação da Suprema Corte acaba por incorporar atribuições excepcionais e consequentemente incorpora em si a atuação dos demais órgãos dos poderes constituídos no Estado Democrático de Direito. À luz da compreensão de Montesquieu quando dissertou sobre a separação de poderes, nota-se que o atual papel do Judiciário brasileiro não somente é a boca da lei, mas modula a lei e seus efeitos dando-lhe interpretação conforme à Constituição. Se questiona se a atuação do STF prejudica a atuação dos demais poderes na gerência do país. Lembramos que para Montesquieu, os poderes deveriam ser controlados pelo próprio poder, como freio dos excessos que eventualmente possam cometer.

Nos últimos anos o Brasil tem experimentado uma verdadeira crise institucional. Os poderes da república, aparentemente, enfraqueceram sua essência funcional. A Constituição Federal de 1988 prevê que os Poderes da União, o Legislativo, o Executivo e o Judiciário, sejam independentes e harmônicos entre si $^{67}$, todavia, o presente cenário prático revela que esta harmonia está relativizada, em virtude do ativismo judicial utilizado pelo Supremo Tribunal Federal, e pelo fato de que os demais poderes sofrem de crise de representatividade. Os poderes Executivo e Legislativo sofreram com os escândalos recentes de corrupção, gerando no descrédito da população nessas instituições.

\footnotetext{
${ }^{67}$ Art. 2o São Poderes da União, independentes e harmônicos entre si, o Legislativo, o Executivo e o Judiciário. Disponível em: http://www.planalto.gov.br/ccivil_03/constituicao/constituicaocompilado.htm. Acesso em 30.08.18
} 
Percebe-se que ao longo da história, a separação dos poderes tem sido objeto de estudo de diversos teóricos da ciência política, tais como Montesquieu, John Locke, Platão, Aristóteles etc. A influência do pensamento de Montesquieu sobre a organização dos poderes, inspirou a Constituição de 1988, que consagrou o modelo tripartite como princípio constitucional.

Além da Carta Magna do Brasil, outros sistemas políticos mundiais, também adotaram a divisão dos poderes, inspiradas por Montesquieu. É importante destacar que a Constituição Federal de 1988 delimitou os limites de cada um dos Poderes da União, a fim de harmonizá-los, com o objetivo de evitar o conflito de competências e interesses de cada um deles.

Ao longo do texto da Carta Magna, estes limites de atuação dos poderes, estão estabelecidos como ferramentas, conhecidas pela teoria dos freios e contrapesos, objetivando evitar os eventuais excessos que cada um dos Poderes da União possa cometer.

A teoria dos freios e contrapesos é conhecida pela doutrina americana como "checks and balances", cujo objetivo é precipuamente barrar a exorbitância de atribuições. Montesquieu afirmava que o todo aquele que tem poder é tentado a usá-lo, e por isso deveria haver um freio, isto é, o poder freia o poder.

O mecanismo dos freios e contrapesos garante a manutenção do equilíbrio institucional entre os Poderes da União, tendo em vista que diante da omissão ou ação de qualquer deles, o sistema permitirá que um poder possa conter as ações ou omissões um do outro. Neste sentido, os pesos e contrapesos possibilitam um controle sobre atos de uns dos outros, tornando possível o limite quanto aos excessos do poder.

Nota-se que o sistema de freios e contrapesos tem a finalidade de promover a harmonia entre os poderes. Seguindo este ponto de partida, um poder, via de regra, não poderá interferir nas esferas de atribuição de outro.

O que tem ocorrido no Brasil, e isto tem sido amplamente divulgado na mídia, é que, rotineiramente, alguns dos Poderes da União, não estão cumprindo com seus deveres institucionais, o que acaba gerando uma atitude de protagonismo, a fim de que se de uma resposta rápida para a sociedade na concretização de seus direitos.

A atuação do Supremo Tribunal Federal, quando se vale dos fenômenos da judicialização das políticas públicas e do ativismo judicial, revela que a crise nacional está instalada. O STF não representa apenas uma corte constitucional, tampouco se limita a função de guardião da constituição, mas tem operado de forma a obrigar o 
Poder Executivo para que, efetivamente, exerça seu papel de gerenciamento e administrador das leis, bem como, tem suprido algumas omissões do Poder Legislativo, quando cria novas regras por meio das suas decisões judiciais.

Muitas questões surgem diante desse fenômeno, dentre as perguntas que se podem fazer é, qual é mais efetiva, a lei ou a decisão judicial? Ou ainda, a omissão da atuação e execução das atribuições dos demais Poderes da União, tem forçado o Supremo Tribunal Federal a suprir essa deficiência? A atuação do STF atende aquilo que chamamos de efetividade dos direitos e garantias fundamentais. Todavia, o alcance das decisões judiciais tem de fato, se revestido de algumas das atribuições dos demais poderes do Estado Democrático Brasileiro, tornando-o portador da última palavra das decisões relevantes de interesse nacional.

\subsection{Separação De Poderes De Montesquieu}

De modo comparativo com a separação de poderes no Brasil e a de Montesquieu, em sua obra, O Espírito das Leis, no capítulo VI do Livro XI, cujo título é "Da constituição da Inglaterra"68, percebe-se que ele descreve a organização da instituição da Inglaterra, que seria um remédio efetivo contra o absolutismo, isto é, contra a concentração exacerbada de poder por um monarca. A ideia de Montesquieu era demonstrar que os homens são tentados a abusar do poder que tem, por isso, ele destaca que esse abuso deveria ser reprimido pelo poder, o poder deve frear o poder. Para ele o sistema inglês proporcionava este tipo de equilíbrio. Tal sistema se tratava do presidencialismo clássico ${ }^{69}$.

A separação de poderes tem a função de evitar a concentração de poder nas mãos de uma pessoa, no caso o monarca, e este instituto surgiu como uma forma de resposta aos regimes absolutistas.

Na compreensão de Montesquieu, em cada Estado há três tipos de poderes, o Legislativo, o Executivo das coisas que dependem do direito das gentes e o poder Executivo das coisas que dependem do direito civil. Em relação ao primeiro poder, o príncipe ou magistrado faz, corrige ou revoga leis. No segundo poder, se faz paz ou

\footnotetext{
${ }^{68}$ MONTESQUIEU, Charles Louis de Secondat, baron de la Brède et de. De l'esprit des lois, vol. I, Paris:Garnier-Flammarion, 2005, p. 294-304. Em Português: de la Brède et de. $O$ espírito das leis, tradução de Fernando Henrique Cardoso e Leôncio Martins Rodrigues,Brasília: UnB, 1995, p. 118-125.

${ }^{69}$ AMARAL JÚNIOR, José Levi Mello do. Sobre a organização de poderes em Montesquieu: Comentários ao Capítulo VI do Livro XI de "O espírito das leis", 2008. Disponível em: https://edisciplinas.usp.br/ - p.2.
} 
guerra, envia ou recebe embaixadas, estabelece a segurança e previne as invasões. Por fim, no terceiro poder o príncipe ou magistrado pune os crimes ou julga as querelas dos indivíduos, o que ele chama de poder de julgar. Montesquieu, também destaca sobre a liberdade política de um cidadão diante de uma estrutura de poderes devidamente distribuída:

A liberdade política, num cidadão, é esta tranquilidade de espírito que provém da opinião que cada um possui de sua segurança; e, para que se tenha essa liberdade, cumpre que o governo seja de tal modo que um cidadão não possa temer outro cidadão ${ }^{70}$.

No que toca a compreensão de Montesquieu sobre o Poder Executivo, a descrição se dá sobre as funções de chefia do Estado e suas relações internacionais. Ele entende que esta atribuição deve permanecer nas mãos de um monarca, pois tal competência é melhor desempenhada por uma única pessoa. Além disso, para Montesquieu, o poder Executivo deve ser privado da iniciativa legislativa, não pode apresentar projetos de lei. $\mathrm{O}$ modelo americano aderiu este entendimento ${ }^{71}$.

Diferentemente do que Montesquieu disse, e do que ocorre nos Estados Unidos, no Brasil, o Presidente da República tem iniciativa legislativa, conforme previsão constitucional $^{72}$.

Expõe Montesquieu, sobre um governo moderado composto pela monarquia, aristocracia e democracia. Os três poderes não podem ser exercidos pelo mesmo sujeito, por isso o ideal é que haja um governo moderado composto pela monarquia, que é o governo de um, aristocracia, governos dos nobres, e a democracia, governo do povo. Este governo moderado age em prol do bem comum.

Sobre esta questão, Montesquieu descreve que:

A democracia e a aristocracia, por sua natureza, não são Estados Livres. Encontra-se a liberdade política unicamente nos governos moderados. Porém, ela nem sempre existe nos Estados moderados: só existe nesses últimos quando não se abusa do poder; mas a experiência eterna mostra que todo

\footnotetext{
${ }^{70}$ MONTESQUIEU, Charles Louis de Secondat. Op. cit. p. 181.

${ }^{71}$ AMARAL JÚNIOR. Op.cit. p. 14.

${ }^{72}$ Art. 84. Compete privativamente ao Presidente da República: III - iniciar o processo legislativo, na forma e nos casos previstos nesta Constituição. Disponível em http://www.planalto.gov.br/ccivil_03/constituicao/constituicaocompilado.htm. Acesso em 17.09.19
} 
homem que tem poder é tentado a abusar dele; vai até onde encontra limites. Quem o diria! A própria virtude tem necessidade de limites ${ }^{73}$.

No que toca o limite dos poderes, Montesquieu defende que eles devem ser neutralizados, para que se coíbam eventuais arbitrariedades. No poder julgador, a forma de neutralização deve se basear no modo de formação dos tribunais e na maneira em que os juízes devem decidir. Este tribunal deve ser composto por pessoas do povo e o exercício da sua atuação deve ter tempo determinado. Para Montesquieu, os juízes são meramente, a boca da lei, não podendo sair dessa esfera de atuação ${ }^{74}$.

Muito embora Montesquieu fosse um pensador avançado para seu tempo, a sua compreensão de poder Judiciário, em alguns aspectos não deve ser adotada hodiernamente, pois, regularmente, o juiz deverá aplicar, não só a lei, mas também seus princípios.

Entretanto, é claro que o propósito de Montesquieu era o de propor um mecanismo de prevenção contra o absolutismo monárquico, que foi posteriormente vencido pela revolução francesa. O esquema de separação de poderes não segue os mesmos padrões que a compreensão que Montesquieu propôs, mas se baseou no seu espírito.

\subsection{O Poder de Julgar em Montesquieu}

Como dissertado anteriormente, o Poder Judiciário para Montesquieu seria o mais fraco dos poderes, pois apenas caberia ao magistrado ser a boca da lei.

Montesquieu alerta que o poder de julgar é terrível entre os homens, sendo que essa atribuição não pode ser exercida de maneira permanente e sim de modo temporário. Ele descreve que os juízes devem ser escolhidos do corpo do povo, ou seja, deveriam ser sorteados. Os magistrados são seres inanimados que não podem manipular a lei com força ou rigor, devendo apenas pronunciar as sentenças da lei. Os tribunais, não deveriam ser permanentes, mas as decisões proferidas por ele sim, o que proporcionaria segurança jurídica ${ }^{75}$.

\footnotetext{
${ }^{73}$ MONTESQUIEU, Charles Louis de secondat. Op. Cit. p.179.

${ }^{74}$ AMARAL JÚNIOR. Op. cit. p. 4-5.

${ }^{75}$ Ibidem. Op. Cit. p.5-6
} 
O Judiciário para Montesquieu representa um poder neutro, sem muita pretensão ao que parece. A pretensão dele, não era de propor uma estatização das instituições, mas as instituições serviriam para limitar os poderes do soberano.

As lições de Montesquieu servem para ilustrar como o poder Judiciário evoluiu ao longo do tempo. A posição que o Judiciário ocupa hoje na tripartição de poderes é tão elevada que, talvez, tenha se tornado o maior dos poderes da administração do Estado.

Roger Stiefelmann entende que Montesquieu via o Poder Judiciário como um poder nulo:

É nítida, no pensamento do mestre francês, a concepção de julgar como uma máquina de silogismos, isto é, a função dos tribunais seria de estrita aplicação da lei, lançando mão apenas do método lógico-interpretativo de subsunção dos fatos à norma ${ }^{76}$.

A noção que Montesquieu tinha do poder Judiciário era diversa da que já existia na Inglaterra do século XVII, onde os juízes desempenhavam uma atividade criadora do Direito. Além disso, ao tratar do Judiciário, Montesquieu destacava que os procedimentos judiciais são fundamentais para que o indivíduo tenha sua liberdade protegida $^{77}$.

A análise que Montesquieu teve do Judiciário, é inspiradora, e revela o seu modo de pensar numa época marcada pelos governos dos déspotas e tiranos. O poder Judiciário evoluiu, e até mesmo aqueles países que encontraram inspiração nas obras de Montesquieu, não se restringiram àquela compreensão, como é o caso dos Estados Unidos $^{78}$.

\subsection{Da Separação dos Poderes no Brasil}

De modo a contextualizar o tema, a separação dos poderes no Brasil e no mundo encontrou inspiração na concepção de Montesquieu e dos liberais, sendo que a essência continua em certa medida a mesma, com os devidos aperfeiçoamentos. A obra

\footnotetext{
${ }^{76}$ LEAL, Roger Stiefelmann. O efeito vinculante na jurisdição constitucional. São Paulo: Saraiva, 2006. p.10.

${ }^{77}$ COSTA, Luciana da Silva. A revisitação do princípio da separação de poderes: dialogicidade e tensão como elementos conformadores da identidade constitucional brasileira. 2014. p. 62.

${ }^{78}$ AMARAL JÚNIOR, Op. cit. p.16.
} 
O Espírito das Leis produziu uma referência efetiva sobre o assunto. O sistema brasileiro acabou por prever o modelo da tripartição dos poderes, sendo eles o Legislativo, o Executivo e o Judiciário.

Sob este prisma, a concepção da divisão dos poderes apresentou previsão constitucional no artigo $2^{\circ}$, dizendo que "São Poderes da União, independentes e harmônicos entre si, o Legislativo, o Executivo e o Judiciário".

Vale destacar que no Brasil, a Constituição de 1824 previa, além dos três poderes, o chamado Poder Moderador, fazendo com que houvesse quatro poderes ${ }^{79}$.

Frisa-se que o constitucionalismo brasileiro teve sua primeira fase iniciada após a declaração da Independência em 1822. O novo Estado manteve as velhas influências portuguesas, ou seja, os traços do colonialismo, a monarquia absolutista e o comercio de escravos permearam todo o sistema político que estava sendo inaugurado ${ }^{80}$.

Nesse sentido, Paulo Bonavides destaca que:

O nosso constitucionalismo, ao revés, levantou-se sobre as ruínas sociais do colonialismo, herdando-lhe os vícios e as taras, e ao mesmo passo, a promiscuidade com a escravidão trazida dos sertões da África e com o absolutismo europeu, que tinha a hibridez dos Braganças e das Cortes de Lisboa, as quais deveriam ser o berço da liberdade e todavia foram para nós contraditoriamente o órgão que conjurava a nossa recaída no domínio colonial. (...) houve um processo de até certo ponto comum de introdução de instituições representativas e constitucionais no que toca à velha metrópole e à nascente nacionalidade..(a) fonte doutrinária fora a mesma; o constitucionalismo francês, vazado nas garantias fundamentais do número 16 da Declaração dos Direitos do Homem e do Cidadão de 26 de agosto de $1789^{81}$.

$\mathrm{Na}$ construção do constitucionalismo monárquico brasileiro, fora convocada uma assembleia constituinte antes da independência e dissolvida em novembro de 1823. Tal proposta constitucionalista, a princípio, não continha a ideia de incorporar um poder moderador no novo Estado, visto que que os poderes do Imperador foram tema de grande controvérsia naquele período

\footnotetext{
79 Art. 10. Os Poderes Politicos reconhecidos pela Constituição do Imperio do Brazil são quatro: o Poder Legislativo, o Poder Moderador, o Poder Executivo, e o Poder Judicial. Disponível em http://www.planalto.gov.br/ccivil_03/Constituicao/Constituicao24.htm acesso 17.09.19

${ }^{80}$ COSTA, Luciana da Silva. Op.cit. p.144

${ }^{81}$ BONAVIDES, Paulo. A evolução constitucional do Brasil. Revista Estudos Avançados. São Paulo, 2000.p. 156 .
} 
Nessa esteira, a Constituição de 1824 tratava do princípio da separação de poderes e previu o sistema bicameral. O Poder Executivo era exercido pelo Imperador, que tinha consigo ministros e um Conselho de Estado. No que compete ao Poder Judiciário, este não era, por assim dizer, um poder autônomo, pois o Poder Moderador poderia interferir na sua atuação. Ao Poder Moderador, competia exercer controle e intervenção nos três poderes, o que de certo modo feria a independência institucional ${ }^{82}$.

Sobre a implementação do Poder Moderador Luciana da Silva Costa assevera:

A inserção do poder moderador buscou inspirações ao menos no plano teórico na proposta, já conhecida na França, especialmente pelos escritos de Benjamim Constant, da teoria tetrapartida de poder. Para Constant, o poder executivo deveria ser apartado do poder real; este seria entregue ao Monarca e, sendo um poder neutro, lhe competiria fiscalizar os demais poderes, velando para que cada um destes não exercesse as suas funções de forma abusiva. O grande jurista do império, Pimenta Bueno, deixou clara tal influência ao discorrer sobre o poder moderador como um poder neutro, entregue àquele que era cercado de respeito e prestígio - o monarca ${ }^{83}$.

A Constituição de 1824, apesar de ter sido alicerçada nas concepções do absolutismo, proporcionou um futuro diferente, pois de certa forma, previu que os poderes deveriam ser divididos, tornando a descentralização das instituições possível.

No período republicano brasileiro, com o advento da Constituição de 1891, houve uma significativa reforma política, mudando completamente a forma do Estado. Passou da monarquia para a república, e esta foi estabelecida como presidencialista superando o parlamentarismo. O unitarismo foi superado pelo federalismo. Tal fenômeno encontrou inspirações no modelo norte americano, por meio de Rui Barbosa, jurista brasileiro.

Sob este prisma, Luciana da Silva Costa, disserta:

No âmbito da organização dos poderes, a adoção da República significou o abandono do poder moderador e a prescrição da teoria tripartide do Poder. A República do papel deu continuidade a um legislativo bicameral (...). Destaque-se a atribuição dada ao parlamento para julgar o Presidente nos casos de crime de responsabilidade. Outro ponto relevante é a observação de

\footnotetext{
${ }^{82}$ COSTA, Luciana da Silva. Op. cit.p. 145-146

${ }^{83}$ Ibidem Op.cit.p. 146
} 
uma função diversa atribuída ao Presidente do Senado Federal- a função de Vice Presidente da República. O Judiciário também foi previsto no âmbito da Constituição, destacando-se o dispositivo que, diretamente, atribuía a este poder a função de realizar o controle de constitucionalidade dos atos normativos. ${ }^{84}$.

Apesar de ter tido a maior duração, a Constituição de 1891, não representou um período de estabilidade política. O período, também foi marcado pelo intervencionismo do poder central nos demais órgãos da federação.

O período da Constituição de 1934, também foi marcado por instabilidade nacional. Ela previu a independência e harmonia dos poderes. O Poder Legislativo permaneceu composto por duas casas, tendo o Senado como possuidor do sistema de freios e contrapesos.

Em 1937 mais uma carta constitucional foi outorgada, marcando o período Vargas, com influências totalitárias e fascistas. A Constituição de 37 marcou um período de desequilíbrio institucional. Deixou de estabelecer o princípio da separação de poderes. O Poder Executivo ganhou mais força, tendo a atribuição de coordenar as atividades dos órgãos representativos, cabendo-lhe, até mesmo, suspender sessões legislativas e deflagrar o processo legislativo. O Poder Executivo também poderia intervir no Poder Judiciário, limitando a sua atuação no que competia as questões exclusivamente políticas, conforme previu o artigo 94 daquele diploma ${ }^{85}$.

Diversamente do que ocorre hoje com os fenômenos do ativismo judicial e com a judicialização da política no Brasil.

Paulo Bonavides e Paes de Andrade dissertam sobre a organização dos poderes na Constituição de 1937 da seguinte maneira:

A competência dos três poderes na Constituição de 1937, era meramente formal. Os artigos 38 e 49 que tratavam do Poder Legislativo esboroavam-se com o conjunto do texto e, mesmo com a coexistência de um Conselho Federal criado pelos artigos 50 e 56, usurpando faculdades legislativas com dez dos seus membros escolhidos pelo Presidente da República e os restantes pelas Assembléias Legislativas dos Estados. Era o senado sem voto popular, constituído já à época dos senadores biônicos que recebiam a designação de

\footnotetext{
${ }^{84}$ COSTA, Luciana da Silva. Op.cit. p.147.

${ }^{85}$ Art 94 - É vedado ao Poder Judiciário conhecer de questões exclusivamente políticas. Disponível em http://www.planalto.gov.br/ccivil_03/Constituicao/Constituicao37.htm - Acesso em 18.09.2019.
} 


\begin{abstract}
"Conselheiros". Quanto ao Judiciário, o arbítrio do Poder Executivo ultrapassava até mesmo o texto da Carta Constitucional. Esta, todavia, deixava a brecha para esses abusos, quando em seu artigo 91, ressaltava as restrições à vitaliciedade, à inamovibilidade, à irredutibilidade dos vencimentos dos magistrados. A competência dos três poderes ficou limitada ao centralismo do Executivo e condicionada aos interesses do chefe do supremo da administração - o Presidente da República ${ }^{86}$.
\end{abstract}

Com o advento no processo de redemocratização, o texto constitucional de 1946 previu a organização dos poderes como independentes e harmônicos. O Poder Legislativo foi restabelecido, trazendo um estatuto de congressistas e prevendo o controle recíproco entre os poderes. O Poder Executivo perde a atribuição de coordenar os demais órgãos, alcançando o mesmo patamar hierárquico dos demais poderes. Em 1965 com a aprovação da Emenda Constitucional $n^{\circ} 16$ fora instituído o sistema de controle abstrato e concentrado de constitucionalidade.

Muito embora a Constituição de 1946 previsse avanços, a instabilidade social mais uma vez foi imposta, agora, pelo regime militar. Neste sentido Luciana da Silva Costa destaca que:

\begin{abstract}
A Constituição de 1946 sucumbiu diante dos decretos e atos institucionais exarados pela Ditadura Militar. Historiadores, cientistas políticos e sociólogos apontam uma diversidade de causas que geraram o declínio da democracia e a ascensão dos militares. Segundo Fico, pesquisas mais recentes estão desmitificando alguns lugares comuns e não conseguem explicar a complexidade de fatores sociais e políticos que explicariam as causas, bem como o desenvolvimento do regime militar $^{87}$.
\end{abstract}

O período marcado pelo regime militar gerou mais uma vez instabilidade política, disso surge a Constituição de 1967 que previu a separação de poderes, todavia, o viés intervencionista aflorou novamente, tendo o Poder Executivo como protagonista.

O desequilíbrio institucional mais uma vez tornou-se regra, e o enfraquecimento dos poderes foi a consequência. Luciana da Silva Costa dispõe que:

\footnotetext{
${ }^{86}$ BONAVIDES, Paulo, Paes de Andrade. História Constitucional do Brasil. Rio de Janeiro: Paz e Terra, 1991, p. 345.

${ }^{87}$ COSTA, Luciana da Silva. Op. cit. p. 150.
} 
(...) o período mais sombrio da história constitucional brasileira. Assim, a pretensa independência do Legislativo era ceifada pela forte intervenção do Executivo: a) de um lado, o famigerado decreto-lei, instrumento normativo de competência privativa do Presidente da República, que podia transformarse em lei por decurso de prazo, ou seja, sem a manifestação do Congresso Nacional; além disso, a impossibilidade de apresentação de emendas parlamentares a essa espécie normativa, demonstrava o quanto o parlamento era afastado de suas competências típicas; b) do outro, o Congresso "Fantoche" perdia a sua autonomia quando posicionava-se na figura de um mero ratificador das decisões já tomadas por uma Comissão de Militares. Na esfera Executiva, as eleições para Presidente e Governador passaram a ser indiretas $^{88}$.

Esse modelo intervencionista proporcionou um ambiente adequado para a edição do Ato Institucional $n^{\circ} 5$, que fortaleceu a supremacia do Executivo sobre os demais poderes. Nessa etapa do processo constitucional brasileiro, o Congresso Nacional teve suas atividades encerradas por três vezes, as prerrogativas dos magistrados foram suspensas, houve aposentaria compulsória de alguns ministros do STF que se opunham ao regime ditatorial e, a postura do STF se mostrou inerte ou não resistente ao governo militar. Em 1974 eclode uma etapa de abertura política, tendo avanços e retrocesso ao mesmo tempo. Em 1983, a abertura política encontra seu ápice no movimento "diretas já", levando a eleição, mesmo que indireta, do primeiro Presidente Civil após o regime ditatorial, Tancredo Neves, sendo o vice José Sarney, que assumirá a presidência após a morte de Tancredo.

Sobre esse período, Daniel Sarmento aponta que:

O movimento que resultou na convocação da Assembleia Nacional Constituinte de 1987/ 1988 só se tornou viável no contexto da crise da ditadura militar, e da lenta transição do regime de exceção em direção à democracia, que se inicia no governo do Presidente Ernesto Geisel, quando, apesar de algumas recaídas autoritárias, começa o processo de abertura política "lenta, gradual e segura", com a derrota da "linha-dura" militar e a revogação do Ato Institucional n ${ }^{\circ} 5$. O sucesso de Geisel, Presidente João Batista de Figueiredo, mantém em linhas gerais o curso do seu antecessor, com a aprovação da Lei de Anistia e a abertura do sistema partidário, que se reorganiza em bases pluralistas. Neste momento, a sociedade capitaneada por

\footnotetext{
${ }^{88}$ COSTA, Luciana da Silva. Op. cit. p. 152
} 
instituições como a $\mathrm{OAB}$, a $\mathrm{ABI}$, a $\mathrm{CNBB}$ e o novo sindicalismo que se formava no País. Essas entidades, com respaldo de alguns meios de comunicação social e de amplas parcelas da população, passaram a exigir a redemocratização nacional ${ }^{89}$.

Já no final de 1986, houve uma nova Constituinte, cujo propósito era o de criar uma nova carta constitucional. A Constituinte foi marcada por debates intensos, tendo como uma das pautas mais discutidas a do sistema de governo que o País iria adotar. A nova Constituição Federal finalmente ganhou corpo e foi promulgada em 5 de outubro de 1988, sendo composta por um texto analítico. Importante destacar que muitas das disposições constitucionais não constavam do projeto original, entre elas, ressalta-se o princípio da separação dos poderes.

Luciana da Silva Costa expõe que:

Em relação à temática "organização dos poderes", a Constituição da República Federativa do Brasil de 1988 dedicou diversos artigos. Assim, inicialmente, dentre o princípios fundamentais, a Constituição prescreve que "são poderes da União, independentes e harmônicos, o Legislativo, o Executivo e o Judiciário". Tal princípio é enumerado, ainda, no artigo 60, $\S 4^{\text {o }}$, III dentre os limites materiais ao Poder de Reforma ${ }^{90}$.

A análise traçada demonstrou que a separação de poderes no Brasil sofreu diversas alterações na sua concepção. Em muitos momentos, esta separação foi acometida por desequilíbrio institucional, tendo a intervenção de um poder sobre o outro. Ademais, ficou claro que o Poder Judiciário não tinha uma atribuição de reivindicar para si uma autoridade de vanguarda em detrimento dos demais Poderes da União.

O que se vê atualmente é que o judiciário, na figura do Supremo Tribunal Federal, se revestiu de um caráter populista, e atribuiu a si mesmo a concepção de que representa a população de um modo geral.

Neste sentido, o princípio da separação de poderes oscila conforme o cenário político se apresenta. É interessante ponderar que, a posição que o Supremo tem

\footnotetext{
${ }^{89}$ SARMENTO, Daniel. 21 Anos de Constituição de 1988: a Assembléia Constituinte de 1987/1988 e a experiência constitucional brasileira. 2009. p. 8

${ }^{90}$ COSTA, Luciana da Silva. Op. Cit. p.157
} 
adotado, se dá pela crise política instalada, o que gerou maior descrédito por parte da população, nos outros poderes, isto é, no Executivo e no Legislativo.

A descrença nos demais poderes da união tornou possível uma atuação mais proativa do Supremo Tribunal Federal, que passa agora a incorporar a ideia de representante do povo, mesmo que seus componentes não tenham sido escolhidos por eles por meio de eleições, haja vista que não há, ainda, a possibilidade de mandato eletivo para ministros da Corte Constitucional ${ }^{91}$.

Questiona-se, até que ponto a Suprema Corte representa os interesses da população? E se representa, de qual população estamos falando? Não parece que essa representatividade seja tão abrangente, e, ainda, o exercício da judicância é, em muitos casos, contramajoritário.

Critica-se que o Supremo Tribunal Federal não atende os interesses da maioria, sendo importante ressaltar que os maiores interessados na atuação do tribunal são entidades políticas com objetivos específicos que nem sempre são de interessantes da população geral. Diz-se que a atuação do Supremo esbarra em interesses oligárquicos, pois o acesso a ele é restrito e nem todos podem arcar com os custos de uma atuação jurídica por lá.

A separação de poderes no Brasil mais uma vez encontra-se em crise. De um lado, deseja-se diálogo institucional, e de outro há uma contenda sobre de quem deve ser a última palavra. A Corte Constitucional do Brasil se vale do fenômeno do ativismo judicial para suprir deficiências dos órgãos de representação, decidindo quase que todas as questões políticas atuais, ante a fragilidade do sistema representativo.

\subsection{O Ativismo Judicial do STF como Fator de Desequilíbrio Entre os Poderes?}

A concepção de alguns juristas do Direito Constitucional moderno tem trazido reflexos sobre a hermenêutica constitucional. O modo como a Constituição Federal tem sido interpretada pelo Supremo Tribunal Federal, sem excluir o caráter personalíssimo dos julgadores, tem gerado dúvidas de quais parâmetros ou critérios adotados para a prolação das suas decisões.

\footnotetext{
${ }^{91}$ Há no Congresso Nacional o projeto de emenda à Constituição $n^{\circ}$ 16/2019 que determina que os próximos ministros escolhidos para compor o Supremo Tribunal Federal (STF) terão mandatos de oito anos, sem direito a serem reconduzidos ao cargo. Disponível em https://www12.senado.leg.br/noticias/materias/2019/03/25/proximos-ministros-indicados-para-o-stfpoderao-ter-mandato-de-8-anos. Acesso em 20.01.2020.
} 
Percebe-se que, apesar da Constituição Federal de 1988 conter inúmeras regras e prescrições específicas, a adequação jurídica na sua aplicação se dá com a subsunção e a ponderação de princípios. A técnica de julgamento dos julgadores da Corte Constitucional, torna clara a utilização dos princípios como parâmetro de julgamento na ausência de regras específicas para se decidir determinados casos.

Os métodos de interpretação constitucionais são variados, sejam eles, o gramatical, teleológico, extensivo, lógico sistemático, tópico etc., a intepretação da norma suprema conterá uma carga valorativa, o que, consequentemente fará com que toda interpretação seja para proteger e concretizar direitos.

Alguns teóricos entendem que nas decisões do Supremo até mesmo as regras estão sendo sopesadas, certo que, em tese, apenas princípios poderiam ser sopesados.

No que tange ao ativismo judicial, segundo o posicionamento críticos, ele acaba por se revestir de diversas roupagens, dentre eles, do neoconstitucionalismo, da técnica da ponderação de princípios, de uma nova hermenêutica constitucional, do pós positivismo etc.

A crítica ao ativismo judicial recai na ideia de que há uma Supremacia Judicial. A compreensão desta ideia é a de que determinadas pessoas são incapazes de se autogovernarem e acabam por transferir esta atribuição para um grupo capaz de realizar tal tarefa ${ }^{92}$.

É interessante perceber que há dúvidas de que como deve se comportar uma Suprema Corte, isto é, se ela deve, diante de um caso concreto em que há conflito com uma determinada norma, dizer o que a lei significa, e, sem dúvida, aplicar ao caso, ou simplesmente descartar a finalidade ou ideia pretendida pela lei em detrimento de interpretações que acabarão por criar novas regras.

Sob este prisma, Sérgio Antônio Ferreira Victor destaca que:

(...) a Corte deve atrelar-se, o máximo possível, ao quanto necessário para solucionar o caso específico, evitando teorizar acerca de questões sobre as quais os juízes não possuem formação adequada, o que pode aumentar os custos relacionados ao erro da decisão ${ }^{93}$.

\footnotetext{
92 MENDES, Conrado Hubner. Direitos fundamentais, separação de poderes e deliberação. 2008. p.162. Acesso em: 2019-9-18.

${ }^{93}$ VICTOR, Sérgio Antônio Ferreira. Diálogo institucional e controle de constitucionalidade: debate entre o STF e o Congresso Nacional - São Paulo: Saraiva, 2015. p. 152.
} 
Outro aspecto crítico do ativismo judicial, é de que ele se vale, também, do mecanismo do controle de constitucionalidade, que, em algumas hipóteses tem sido visto com desconfiança na concepção de democracia. Os que se valem desse mecanismo de controle, acabam por ter prevalência quando interpretam as normas constitucionais e se conjunto de direitos fundamentais. A celeuma persiste entre essa atuação do judiciário e o papel do legislativo que deveria sobrepor esta hipótese de ativismo.

Em visto disso, é imperioso destacar que o Supremo Tribunal Federal não age de ofício, mas sim quando provocado, ou seja, quando se busca sua tutela ou seu posicionamento em determinado tema.

Ademais, o princípio da separação de poderes sofreu evoluções significativas desde suas concepções originais. A crise atual se deu pela fragilidade dos órgãos de representação, possibilitando a evolução do Poder Judiciário, que teve suas funções ampliadas, tendo em vista suas limitações durante o regime de exceção.

No Brasil o que proporcionou sem dúvida essa ampliação, foi o desenvolvimento do controle de constitucionalidade e a própria característica das normas constitucionais insculpidas na CF 88 , que abrem margem para utilização dos princípios como regras hermenêuticas o que culminou numa atitude mais presente do judiciário.

Eber de Meira Ferreira ao fazer uma abordagem profunda sobre este fenômeno, ele disserta que:

\begin{abstract}
A Assembleia Constituinte de 1988 deu ao Poder Judiciário matéria-prima que lhe permite adentrar em questões morais que no mais das vezes residem no campo das opções políticas e legislativas da sociedade, ou deveriam ser desenvolvidas em um processo de amadurecimento com ampla participação dos atores sociais. Ao integrarem o bloco de constitucionalidade, cláusulas abertas e princípio de conteúdo amplo, muitas vezes interpretados com alto grau de discricionariedade por aqueles a quem incumbe sua aplicação, permitem uma margem de interpretação e de opção no exercício do controle de constitucionalidade que ampliam os limites da atuação deste juris dicere ${ }^{94}$.
\end{abstract}

Apesar das extensas prerrogativas que a Constituição Federal de 1988 deu ao STF, o ativismo judicial se abraça, também, com a concepção do neoconstitucionalismo, doutrina que teve seu desenvolvimento recente, mais precisamente no início do século XXI, que traz um nova perspectiva em relação ao

\footnotetext{
${ }^{94}$ FERREIRA, Eber de Meira. Poder judiciário, ativismo judicial e democracia. 2014. p. 66.
} 
constitucionalismo. O neoconstitucionalismo é chamado também de constitucionalismo pós-moderno, e até mesmo pós-positivismo ${ }^{95}$.

O objetivo do neoconstitucionalismo está em alcançar a eficácia da Constituição, retirando do texto da norma o caráter meramente retórico e tornando-o mais efetivo, na medida em que se busca a concretização dos direitos fundamentais ${ }^{96}$.

O fenômeno do neoconstitucionalismo não é um fato incontroverso e imune às críticas. Essa nova concepção de se compreender o direito constitucional não é unânime, e encontra inúmeras divergências, sejam elas práticas, doutrinárias e acadêmicas.

Quanto àqueles que divergem das posições neoconstitucionalistas, destaca-se, dentre eles, o professor Manoel Gonçalves Ferreira Filho, que diz que o neoconstitucionalismo se apresenta como uma verdade consagrada e indiscutida e que seus adeptos desconsideram as regras constitucionais, em detrimento dos princípios.

Segundo ele, o neoconstitucionalismo baseia-se em teorias em que se está num Estado pós-moderno e, consequentemente, o direito também é pós-moderno. Ele destaca que o neoconstitucionalismo tem a aparência de uma ciência, ou seja, é travestida de ciência, mas seu conteúdo não o é. Para ele, os neoconstitucionalistas consideram aqueles que defendem o positivismo como ultrapassados e, por tal razão, apelida este novo direito de "neoconstitucionalismo à brasileira" 97 .

Agasalhado com o neoconstitucionalismo, o Supremo Tribunal Federal teria ganhado proeminência no cenário nacional ao decidir diversas questões que influenciarão diretamente os direitos individuais e coletivos.

Outrossim, no mesmo sentido, grandes teóricos e juristas afirmam que estamos vivendo numa supremacia judicial, ou sob o olhar de Oscar Vilhena Vieira, numa "supremocracia". Ele aponta que o STF está no centro do atual sistema político, sendo que este fenômeno representa a fragilidade do sistema representativo. Segundo ele, o STF está exercendo uma função legislativa, ao criar regras e ainda absorvendo a atribuição de intérprete da Constituição ${ }^{98}$.

Entretanto, a falha no sistema representativo abriu espaço para este tipo de postura do STF, o que em tese, não é adequado para a harmonia entre os Poderes da União, que, segundo salienta a Constituição Federal, devem ser independentes entre si.

\footnotetext{
${ }^{95}$ LENZA, Pedro. Direito Constitucional Esquematizado. São Paulo: Saraiva, 2012. p.61.

${ }^{96}$ Ibidem. p.62

${ }^{97}$ FERREIRA FILHO, Manoel Gonçalves. Notas sobre o direito constitucional pós-moderno, em particular sobre certo neoconstitucionalismo à brasileira. p. 151.

${ }^{98}$ VIEIRA, Oscar Vilhena. Supremocracia. 2008. p. 441.
} 
Incorporar atribuições legislativas não deve ser a máxima de uma suprema corte, tanto que ela não pode ser considerada, em sentido estrito, um órgão representativo, pois seus componentes não foram eleitos pelo povo e logo, não exprime a sua vontade.

Os difusores do neoconstitucionalismo e aqueles que entendem que a postura de uma corte constitucional está correta quando se judicializa, basicamente todas as questões, destaca-se o ministro Luís Roberto Barroso, que expõe que os tribunais constitucionais, em várias partes do mundo, tornaram-se protagonistas das discussões políticas ou morais em temas controvertidos. Com a atuação do Poder Judiciário do Brasil, o tribunal ganhou força em questões relevantes, o que resultou na judicialização da vida e no ativismo judicial.

No tocante ao ativismo judicial e a judicialização, Luís Roberto Barroso entende que:

\begin{abstract}
“(...) Judicialização significa que questões relevantes do ponto de vista político, social ou moral estão sendo decididas pelo Judiciário. Trata-se, como intuitivo, de uma transferência de poder das instâncias tradicionais, que são o Executivo e o Legislativo, para juízes e tribunais. (...) O ativismo é uma atitude, é a deliberada expansão do papel do Judiciário, mediante o uso da interpretação constitucional para suprir lacunas, sanar omissões legislativas ou determinar políticas públicas quando ausentes ou ineficientes." ${ }^{.99}$
\end{abstract}

De certa forma, o ativismo judicial representaria uma forma de ação vigorosa do Poder Judiciário em detrimento dos outros poderes, mais especificamente, o Legislativo. Com o ativismo, o Supremo Tribunal Federal torna-se legislador, ao criar novas regras ou dar interpretação mais extensiva do que está no texto da lei e até mesmo na própria Constituição ${ }^{100}$.

A concepção que o Supremo Tribunal Federal tem de si mesmo não deixa dúvidas sobre seu papel. Por meio das decisões que vêm prolatando, fica claro que está se valendo de conceitos amplos e princípios dos mais diversos, para fundamentar suas

\footnotetext{
${ }^{99}$ BARROSO, Luís Roberto. Direito e política: a tênue fronteira ou judicialização, ativismo judicial e democracia. 2012. Disponível em: http://www.migalhas.com.br/dePeso/16,MI156926,41046Direito+e+politica+a+tenue+fronteira+ou+judicializacao+ativismo acesso em 18.09.19

${ }^{100}$ Um caso emblemático julgado pelo STF foi o da união homoafetiva na ADI 4277 e na ADPF 132 quando deram interpretação conforme a Constituição Federal do artigo 1.723 do Código Civil e interpretaram extensivamente o artigo $226 \quad \S 3^{\circ}$ da $\mathrm{CF}$. (Disponível em: http://www.stf.jus.br/portal/cms/verNoticiaDetalhe.asp?idConteudo=178931 acesso em 19.09.19).
} 
decisões, sob o fundamento de que também representa os interesses e anseios da sociedade.

Com o objetivo de ilustrar essa posição, convém exportar um trecho do voto do ministro Gilmar Mendes, na ADI 3.510 do Distrito Federal, que tratou da pesquisa com células tronco embrionárias:

O Supremo Tribunal Federal demonstra, com este julgamento, que pode, sim, ser uma Casa do povo, tal qual o parlamento. Um lugar onde os diversos anseios sociais e o pluralismo político, ético e religioso encontram guarida nos debates procedimental e argumentativamente organizados em normas previamente estabelecidas. As audiências públicas, nas quais são ouvidos os expertos sobre a matéria em debate, a intervenção dos amici curiae, com suas contribuições jurídica e socialmente relevantes, assim como a intervenção do Ministério Público, como representante de toda a sociedade perante o Tribunal, e das advocacias pública e privada, na defesa de seus interesses, fazem desta Corte também um espaço democrático. Um espaço aberto à reflexão e à argumentação jurídica e moral, com ampla repercussão na coletividade e nas instituições democráticas ${ }^{101}$.

Este recorte do voto nos revela que o STF, de forma objetiva e consciente, reivindica pra si atribuições democráticas e efetivamente, demonstra que se considera efetivo, ante a ineficácia dos demais Poderes da União. A crise institucional é evidente quando observa-se um comportamento protagonista como esse.

O ano de 2019 foi marcado pelo período pós eleitoral, cuja mudança no cenário político encontrará reflexos nos próximos 4 anos. Acompanhando os debates dos presidenciáveis no ano eleitoral de 2018, observou-se que, dentre algumas propostas, está em pauta a modificação na composição do Supremo Tribunal Federal, dobrando o número de seus ministros, como também, há os que defendam que a forma de nomeação seja alterada, estabelecendo mandato e prazo determinado para os próximos ministros que comporão a corte.

Não são poucas as ideias dos candidatos à Presidência da República em 2018 para modificar o quadro político. O que não se pode é aceitar o desequilíbrio dos Poderes da União, pois a consequência disto trará mais retrocessos do que avanços.

\footnotetext{
${ }^{101}$ Supremo Tribunal Federal. ADI nº3510. Voto do Ministro Gilmar Mendes. Julgamento 29/05/2008.
} 
Sérgio Antônio Ferreira Victor, citando Jeremy Waldron, destaca que, para o restabelecimento do equilíbrio institucional, é necessário que a atenção dos juristas esteja voltada ao Poder Legislativo, tratando-o com a devida dignidade ${ }^{102}$.

Sob este prisma, Jeremy Waldron destaca que:

\begin{abstract}
Quero que vejamos o processo de legislação - na sua melhor forma - como algo assim: os representantes da comunidade unindo-se para estabelecer solene e explicitamente esquemas e medidas comuns, que se podem sustentar em nome de todos eles, e fazendo-o de uma maneira que reconheça abertamente e respeite (em vez de ocultar) as inevitáveis diferenças de opinião e princípio entre eles. Esse é o tipo de compreensão de legislação que eu gostaria de cultivar. E penso que, se capturássemos isso como a nossa imagem da legislação, haveria, por sua vez, uma saudável diferença no nosso conceito geral do direito ${ }^{103}$.
\end{abstract}

A atuação do STF, sem dúvida, tem gerado desconforto institucional, colocando a atuação dos outros Poderes da União como frágil. Talvez a solução para neutralizar este fenômeno, seja repensar o modo de composição do tribunal, repensar o controle de constitucionalidade e limitar os critérios de competência de julgamento em determinadas questões, ou ainda fomentar o diálogo institucional, a fim de possibilitar uma dinâmica na eficiência do poder público.

Não é o direito uma ciência absoluta, tampouco seus operadores não são os que possuem a última palavra em todos os aspectos. O diálogo institucional é a medida para a maior efetividade da democracia e o reestabelecimento do equilíbrio entre os três poderes.

Portanto, percebe-se com isto que o ativismo judicial não é o fator de desequilíbrio institucional, pois revela que a divisão dos poderes não foi afetada, pois seu funcionamento não foi comprometido, pelo contrário, ele impulsionou uma atuação mais expressiva dos outros órgãos, gerando maior mobilização política. A separação de poderes promovida pelo pensamento de Montesquieu, deu início à organização do Estado Democrático de Direito. Desse modo, é importante asseverar que posicionamentos jurídicos não devem ser levados como mera retórica pra reivindicar atribuições diversas daquelas estabelecidas pela Constituição Federal.

\footnotetext{
${ }^{102}$ VICTOR, Sérgio Antônio Ferreira. Op. cit. p.160.

${ }^{103}$ Apud VICTOR, 2015. p.160 - WALDRON, Jeremy. A dignidade da legislação. São Paulo: Martins Fontes, 2003, p.2.
} 
O ativismo judicial se vale do controle de constitucionalidade para suprir os espaços deixados pelos demais poderes nacionais. Sua incidência, de nenhum modo, deve ser permanente, pois sua eternalização acabaria por desaguar em tirania, exatamente o oposto do que pretendia Montesquieu.

Montesquieu já destacava que o poder de julgar é perigoso e que todo aquele que o detém, é tentado a abusar dele, e por isso, na sua compreensão, o julgador deveria ser, tão somente, a boca da lei.

Ademais, conforme anteriormente mencionado, Montesquieu era cético em relação à democracia, destacando que nem todos os homens poderiam votar. Muito embora o modelo representativo encontre falhas, este é o modo pelo qual o povo e todos os seus grupos, podem ser representados, pois assim o fizeram ao eleger seus candidatos.

O Supremo Tribunal Federal não é, via de regra, um órgão representativo, no sentido político, apesar da sua grande importância em poder fazer o papel de protetor da Constituição.

Não há dúvidas de que, quando um dos poderes falha, é necessário que alguém se posicione para que esta grande máquina que é o Estado não pare de funcionar.

Não se pode deixar de observar que o Supremo Tribunal Federal age quando é provocado. A provocação jurisdicional é o que representa o sistema processual brasileiro. Todavia, quando ao ser provocado, o STF em alguns momentos, vai além de sua esfera de competência, para que os demais Poderes da União se mobilizem no respeito à Constituição e seus ditames.

Viu-se que no ano eleitoral de 2018 falou-se em inúmeras reformas, e até mesmo em "mini constituinte", o que sem dúvida se acontecer, prejudicará o Direito Constitucional vigente que até aqui foi construído, ocasionando na perda, daquilo que se busca de modo feroz, a segurança jurídica. 


\section{O SUPREMO TRIBUNAL FEDERAL E O ATIVISMO JUDICIAL}

O papel do Supremo Tribunal Federal tem sido, como visto anteriormente, objeto de severas críticas, no que tange ao seu modo de atuação. Dentro dessa perspectiva, dissertou-se sobre o ativismo judicial como meio de concretização dos direitos e garantias fundamentais e de representação democrática, bem como que essa postura não acarreta em desequilíbrio institucional.

Desse modo, a judicialização da política também tem sido objeto de intensos debates, talvez porque estão difundidos diversos posicionamentos doutrinários, que saem da esfera jurídica.

O Supremo Tribunal Federal, com o advento da Constituição Federal de 1988 adquiriu uma expansão nas suas atribuições, tornando um Poder Judiciário forte. Por adquirir força, o STF tem sido acusado de usurpar funções exclusivas dos demais poderes da república, sendo responsável por, supostamente, interferir na legitimidade dos demais poderes. Em contrapartida, tem sido visto como órgão capaz de trazer estabilidade institucional, diante da atuação deficitária dos poderes Executivo e Legislativo. Sobre o conceito de judicialização da política, Patrícia Carvalho Ribeiro aponta:

\footnotetext{
Essa última expressão foi introduzida por Tate e Vallinder nos EUA, em 1995, quando passou a compor o repertório da Ciência Social e do Direito. Esses autores definiram, em linhas gerais, a judicialização da política como os efeitos da expansão do Poder Judiciário no processo decisório das democracias contemporâneas. É um fenômeno que ocorre em escala mundial a partir da combinação das tradições constitucionais e dos arranjos políticos de cada país. Os autores ressaltam que a judicialização da política ocorre em sistemas democráticos e requer um Poder Judiciário forte ${ }^{104}$.
}

Do posicionamento acima, pode-se notar que o instituto da judicialização da política é presente em sociedades democráticas que fortalecem a atuação do Poder Judiciário. Um judiciário fortalecido proporciona a concretização das garantias constitucionais.

\footnotetext{
${ }^{104}$ RIBEIRO, Patrícia Carvalho. Judicialização da Política - Estudos de casos. 2008, p.16. Disponível em http://bd.camara.gov.br/bd/handle/bdcamara/5828. Acesso 09.10.19
} 
Todavia, o fortalecimento do Poder Judiciário não é um fato antigo, pois o Brasil atravessou um período de exceção imposto pelo regime militar de 1964 a 1985. Neste momento da história brasileira, direitos e garantias individuais foram frontalmente limitados, em razão das imposições estabelecidas pelos Atos Institucionais do governo militar.

Durante o regime de exceção no Brasil, a Europa e os países ocidentais no período pós-guerra, elaboraram documentos que tratavam da proteção da dignidade humana, bem como de direitos e garantias fundamentais. $\mathrm{O}$ oposto disto ocorria no Brasil.

Vê-se que, o advento da Constituição Federal de 1988 foi a alavanca impulsionadora da redemocratização do Brasil, e sua promulgação restaurou os direitos e garantias fundamentais e a proteção às liberdades individuais, que foram violentamente afetados durante o regime militar.

A Constituição Federal de 1988 é extensa na dimensão da garantia dos direitos fundamentais, sendo que estes poderiam encontrar previsão nas leis infraconstitucionais. Ela trata basicamente de todas as questões de um Estado Democrático de Direito. Essa característica protecionista e garantista da Carta Magna se justifica pelo período militar que fora instalado anteriormente, e serve para proteger os cidadãos, de um modo geral, de um possível retorno daquele governo. O momento histórico em que a Constituição Federal de 1988 está inserida, fez com que a Assembleia Nacional Constituinte adotasse essa postura.

A expectativa pela reabertura democrática no Brasil, objetivou a restauração das proteções às liberdades individuais, tendo em vista que no País havia um imenso atraso humanístico em relação aos outros países ocidentais do mundo. Esse atraso inspirou o legislador originário a expressar na Carta Magna a proteção aos direitos políticos e sociais, temas estes que em muitos trechos da Constituição, são tratados como normas programáticas, a fim de serem alcançadas a médio ou longo prazo pelo poder público.

O conteúdo programático da Constituição Federal de 1988, tinha o o objetivo precípuo de sua implementação e efetivação ao longo do desenvolvimento do País. Nesse sentido, Ulysses Guimarães, presidente da Assembleia Nacional Constituinte discursa: 
Declaro promulgada! O documento da liberdade, da dignidade, da democracia, da justiça social do Brasil! Que Deus nos ajude para que isso se cumpra! Com esta frase, proferida em 5 de outubro de 1988, o deputado Ulysses Guimarães, presidente da Assembleia Nacional Constituinte, promulgou a Constituição da República Federativa do Brasil ${ }^{105}$.

Algumas disposições revolucionárias foram inseridas na Constituição Federal de 1988, dentre elas destacam-se:

A Constituição de 1988 colocou a Educação como dever do Estado, inclusive para quem não teve acesso ao ensino na idade certa. Foi ampliada a educação rural e enfatizados os esforços para incluir as crianças com deficiência e a população indígena; A defesa do consumidor também foi introduzida como um direito fundamental. O Código de Defesa do Consumidor foi elaborado por determinação expressa da Constituição. A nova Carta também garantiu ao brasileiro o pleno acesso à Cultura e conferiu ao Estado a obrigação de proteger todos os tipos de manifestações tipicamente nacionais, como a indígena, a popular e a afro-brasileira; A Constituição de 88 reconheceu a importância da biodiversidade ao dedicar um capítulo ao Meio Ambiente. Passou a exigir avaliação de impacto ambiental para obras e abriu caminho para legislações posteriores, como a Lei das Águas e a Lei dos Crimes Ambientais; Outra revolução importantíssima após tantos anos de regime militar foi a possibilidade de os cidadãos apresentarem projetos de lei, com a assinatura de $1 \%$ dos eleitores do País ${ }^{106}$.

Outros pontos importantes trazidos no bojo da Constituição Cidadã é que ela, como mencionado, amplia liberdades civis e garantias individuais, bem como, retoma as eleições diretas, acaba com a censura à imprensa, confere direito de voto aos analfabetos, prescreve mais direitos trabalhistas e reforma o sistema tributário.

Em seu teor, a Carta Magna de 1988 também disciplina matérias de ordem política, conferindo aos poderes Legislativo e executivo a atribuição de sua efetividade. Contudo, é importante destacar que a concretização das normas constitucionais não foram plenamente implementadas até o momento. No período em que esta pesquisa fora escrita, a Constituição de 1988 completou 31 anos de existência, e já sofreu 102

105 Trecho extraído do texto 30 anos da Constituição Federal de 1988. Disponível em https://www.camara.leg.br/internet/agencia/infograficoshtml5/constituinte/index.html?utm_source=What VDigital\&utm_medium=banner\&utm_content $=$ Tecnologia\&utm_campaign=noticiasutm_source $=$ WhatV Digital\&utm_medium=banner\&utm_content=Tecnologia\&utm_campaign=noticias. Acesso em 10.10.19. ${ }^{106}$ Ibidem 
emendas, sendo a última a 102 de 26.09.2019, que deu nova redação ao art. 20 da Constituição Federal e altera o art. 165 da Constituição Federal e o art. 107 do Ato das Disposições Constitucionais Transitórias ${ }^{107}$.

As disposições constantes dos artigos $6^{\circ}$ e $7^{\circ}$ da $\mathrm{CF} / 88$, que dispõem sobre os direitos sociais, disciplinam as matérias relativas à saúde, educação, moradia, lazer etc. Todavia, estes direitos ainda não foram alcançados de maneira efetiva. Para que se alcance o ideal da concretização dos direitos constitucionais, faz-se necessário a promoção de políticas públicas pelo Poder Público, surgindo a necessidade de o Estado proporcionar o bem estar social que a Constituição Federal prega.

É de ressaltar que a concretização dos direitos fundamentais e sociais previstos na Constituição de 1988, necessitam de políticas públicas efetivas a serem promovidas pelo Estado. A viabilização das políticas públicas deve ser feita, exclusivamente, pelos poderes Legislativo e Executivo, que são os órgãos de representatividade nacional e caracterizam-se pela expressão da vontade popular.

Em contrapartida, o que verifica-se é que a atuação dos referidos poderes em promoverem políticas públicas não tem sido suficientes para responderem aos anseios da sociedade.

O que fica muito claro é que os órgãos de representação nacional tem se colocado ao lado de grupos de interesses pessoais, que não respondem por toda a sociedade. $\mathrm{O}$ ambiente político nacional nos mostra que ainda há muitas carências na efetividade das políticas públicas, que restam insuficientes para o ideal que se espera, conforme previsão constitucional.

Essas deficiências e omissões nos órgãos representativos forçam o cidadão brasileiro a buscar a efetivação dos direitos e garantias fundamentais por meio do Poder Judiciário, que termina por incorporar a atribuição de representante democrático daqueles que buscam sua tutela.

Diante desses fenômenos, a judicialização da política surge como solução, mesmo que temporária, para possibilitar equilíbrio institucional e garantia dos direitos fundamentais. Para Ernani Rodrigues Carvalho, a "judicialização é a reação do

\footnotetext{
107 Disponível em http://www.planalto.gov.br/ccivil_03/constituicao/emendas/emc/quadro_emc.htm.
} Acesso em 10.10.19. 
Judiciário frente à provocação de um terceiro e tem por finalidade revisar a decisão de um poder político tomando com base a Constituição" 108 .

Muito embora, para a prática da judicialização da política, o Supremo Tribunal Federal não pode agir de ofício. Sua atuação na judicialização das políticas públicas, exige necessariamente a provocação de um terceiro. $O$ terceiro interessando em obter a tutela jurídica para a efetivação de determinados direitos fundamentais recorre ao Supremo Tribunal Federal, cuja incumbência é a de ser o guardião da Constituição ${ }^{109}$, e, além disso, promover o seu efetivo cumprimento.

Confirma-se que o motivo pelo qual os cidadãos recorrem ao Pode Judiciário para obter a efetivação de um direito, está na crise de representatividade e de funcionalidade dos demais poderes. A sociedade espera que os poderes de representação, atendam as demandas previstas no texto constitucional, devendo haver providências concretas na sua aplicação. Outro fator é que, por haver direitos constitucionais e por ser o STF o guardião da Constituição, é que se recorre a corte para suprir os espaços deixados pelos demais órgãos da república.

Acerca do papel da justiça frente ao descrédito dos demais poderes da nação, Antoine Garapon assevera:

\footnotetext{
O sucesso da justiça é inversamente proporcional ao descrédito que afeta as instituições políticas clássicas, causado pela crise de desinteresse e pela perda do espírito público. A posição de um terceiro imparcial compensa o 'déficit democrático' de uma decisão política agora voltada para a gestão e fornece à sociedade a referência simbólica que a representação nacional lhe oferece cada vez menos ${ }^{110}$.
}

Sobre a Constituição e sua extensão, Carlos Bastide Horbach destaca que "a Constituição de 1988 é muito abrangente, dispõe sobre tudo, muito já se falou" "111. Sob este prisma, percebe-se que a judicialização da política pela sociedade na concretização de seus direitos, ocorre justamente pela extensa disposição de direitos na Carta Magna.

\footnotetext{
${ }^{108}$ CARVALHO, Ernani Rodrigues. Em busca da judicialização da política no Brasil: apontamentos para uma nova abordagem. 2004, p.127.

109 Art. 102. Compete ao Supremo Tribunal Federal, precipuamente, a guarda da Constituição (...). Disponível em http://www.planalto.gov.br/ccivil_03/constituicao/constituicaocompilado.htm Acesso em 14.10.19

${ }^{110}$ GARAPON, Antoine. O Juiz e a Democracia - o guardião das promessas. 1999, p.48.

${ }^{111}$ HORBACH, Carlos Bastide. Op. cit. p.8.
} 
A judicialização da política não acontece por vaidade institucional, mas em razão da crise de representatividade dos demais poderes. Não se vê saída para a concretização dos direitos fundamentais, senão por meio da ação judicial. A atuação do Poder Judiciário não deve ser uma medida permanente na prática da judicialização. As transformações da sociedade devem contribuir para que os poderes da república possam agir dentro das suas esferas de atuação, e, se eventualmente um deles deixar de realizar suas funções precípuas, o Supremo Tribunal Federal agirá como o poder moderador. Visto que o tema da judicialização da política não encontra plena aceitação para os acadêmicos, pois se entende que com essa prática da judicialização da política, há afronta diretamente ao princípio da separação dos poderes. Nesse sentido, disserta Daniel Giotti de Paula:

\begin{abstract}
As políticas públicas, com efeito, passam a ser repartidas, desproporcionalmente, entre o judiciário e os demais Poderes e é este o elemento primordial a ser analisado pela doutrina. Ainda que sobre a perspectiva econômica, o problema que se coloca, aqui é de legitimação, passando pela possibilidade de os custos do financiamento das despesas serem impostos, a toda sociedade, de forma contramajoritária, ou seja, sem que os contribuintes, atuais ou futuros, tenham concordado com isso ${ }^{112}$.
\end{abstract}

A crítica acima é notabilizada pela alegação de ausência de legitimidade do Poder Judiciário para determinar a efetivação das políticas publicas, impondo aos demais poderes essa função.

Destaca-se que é função do poder público a efetivação das políticas públicas. O Poder Legislativo é o órgão de representação nacional e, em tese, representa os interesses dos cidadãos de um modo geral. O Legislativo, ao elaborar e publicar as leis, de certa forma impõe ao Poder Executivo, em todos os seus níveis, o dever de cumprimento e execução das leis, assegurando a implementação das políticas públicas.

Os poderes Executivo e Legislativo tem em comum o caráter representativo. Seus agentes são eleitos pelo povo, e o voto é a expressão da vontade popular. Excetuando-se os cargos políticos comissionados que não são de caráter eletivo, os cargos ocupados pelos líderes do Executivo e os parlamentares, em tese, se revestem do aspecto democrático.

${ }^{112}$ PAULA, Daniel Giotti de. Uma leitura crítica entre ativismo e judicialização da política. 2011, p.27. 


\subsection{O Caráter Democrático do Supremo Tribunal Federal}

Destarte, O Supremo Tribunal Federal, em regra, não constitui-se como órgão representativo, posto que seus componentes não foram eleitos pelo povo, e não caracteriza-se, em tese, pela expressão da vontade popular. Todavia, como verifica-se, as deficiências dos demais poderes, sobretudo, do Poder Legislativo, deram espaço para a judicialização das políticas públicas e para o ativismo judicial. Isso fez com que o Supremo Tribunal Federal se revestisse de representante democrático, uma vez que as políticas públicas reclamam um anseio urgente da sociedade.

As crises institucionais não são recentes, nesse sentido, preleciona Michel Temer:

Desde a Constituição republicana de 1891, sempre tivemos crise institucional no Brasil. A cada período de vigência de uma Carta Magna, as crises se sucediam. Tivesse, ou não, a Constituição, conteúdo democrático. Foi assim em 1891, com a primeira Constituição, editada logo depois do Decreto $\mathrm{n}^{\circ} 1$, de 15 de novembro de 1889 que proclamou a República como forma de governo e a Federação como forma de Estado. Inspirou-se na Constituição norte-americana. Por isso, trouxe em seu interior as teses do liberalismo. As amplas liberdades não evitaram crises de consequências políticas dramáticas: Guerra de Canudos, Revolta da Chibata, Guerra do Contestado, o Movimento Tenentista e a Coluna Prestes. Tudo isso até o golpe de 1930 quando se inaugurou sistema declaradamente diretorial que perdurou até $1934^{113}$.

As crises institucionais forçam a sociedade à transformação, que reformulam ideias, valores, culturas e o próprio modo de se enxergar a política. Além disso, as crises institucionais fortaleceram o Poder Judiciário, para que este viabilize os anseios da sociedade por meios dos mecanismos processuais de controle de constitucionalidade.

Dentro tema da judicialização das políticas públicas, Luciana de Toledo Temer Lulia e Natalia Rosa Pellicciari dissertam:

A judicialização das políticas públicas pode ser definida, em síntese, como a transferência de poder das instâncias tradicionais, que são o Executivo e o Legislativo, para juízes e tribunais, de modo que questões relevantes do ponto de vista político, social ou moral estão sendo decididas pelo Judiciário.

\footnotetext{
${ }^{113}$ TEMER, Michel. Por uma democracia eficiente. 2013, p. 4.
} 
Tal fenômeno é visto desde o final da segunda guerra mundial, em muitas democracias, verificando-se um certo avanço da justiça constitucional sobre o avanço da política majoritária, que é aquela feita no âmbito do Legislativo e do Executivo ${ }^{114}$.

Imperioso destacar que foi através dos processos democráticos, que as supremas cortes adquiram notabilidade institucional, tendo por certo que, em regimes de exceção, elas eram controladas pelos regimes autoritários, que se valiam dos julgamentos para perseguirem seus inimigos. Conforme mencionado, aqueles que criticam o fenômeno da judicialização alegam que os magistrados não foram eleitos, e por isso sua atuação deve se limitar especificamente sobre sua atuação judicante, ficando, então, impedidos de ultrapassar quaisquer limites inerentes às suas atribuições funcionais.

O Poder Judiciário, segundo a opinião crítica, está desprovido de legitimidade democrática, pois considera-se que não possuem capacidade institucional para tratar de assuntos de relevância nacional, dentre eles, as políticas públicas.

O Supremo Tribunal Federal exerce caráter representativo, pois atua com a concretização das demandas sociais que não foram atendidas de pronto pelo Poder Legislativo, bem como age para completar o ordenamento jurídico quando há situações de omissão por parte do legislador. Nessa medida, algumas decisões do Supremo Tribunal Federal defendem os interesses da maioria da população, quando esta clama ao Poder Público uma posição e este se revela inerte.

Nesse sentido, o Supremo Tribunal Federal age com o fito de evitar que o sistema democrático, se torne um regime serviente a privilégio de grupos organizados, que, por sua vez, tem grande poder de influência política e econômica na sociedade.

Sobre a questão da democracia e do constitucionalismo Richard Bellamy destaca:

O termo "democracia constitucional" pode ser interpretado como um oximoro ou uma tautologia. Por um lado, o constitucionalismo e a democracia podem parecer opostos um ao outro. Enquanto que o primeiro termo refere-se ao poder "contido e dividido", o segundo implica a sua "unificação" e exercício irrestrito. Por outro lado, as constituições podem ser apresentadas como as regras do jogo democrático, indicando quem pode votar, como, quando e por

\footnotetext{
${ }^{114}$ LULIA, Luciana de Toledo Temer. PELLICCIARI, Natalia Rosa. Uma reflexão sobre a judicialização das políticas públicas com base na questão das cotas sociais e raciais. 2016, p. 3.
} 
que. Desde o ideal democrático envolve mais do que mera adesão aos dispositivos processuais formais de democracia, como o governo da maioria. Muitos constitucionalistas argumentam que nenhum verdadeiro democrata consistentemente permitirá que uma democracia se elimine. Não há contradição, portanto, em entrincheirando os direitos que são inerentes ao próprio processo democrático e impedindo sua revogação até mesmo por políticos democraticamente eleitos. Por conseguinte, é inconstitucional, em vez de uma democracia constitucional, que representa uma contradição em termos $^{115}$.

Importante salientar que o princípio da separação dos poderes sofreu alterações fundamentais desde sua criação. Dentro das possíveis alterações, nota-se a evolução do Poder Judiciário e a ampliação de suas funções. No caso brasileiro o Poder Judiciário avançou, visto que adquiriu um papel de destaque político/constitucional após a promulgação da Constituição de 1988. Aliados a esses avanços estão o desenvolvimento do controle de constitucionalidade, como afirmado anteriormente e as características das normas constitucionais, que, por sua vez, implicam no ativismo judicial. Sob este prisma, Alexandre de Moraes aponta:

No Brasil, a partir do fortalecimento do Poder Judiciário e da Jurisdição Constitucional pela Constituição de 1988, principalmente pelos complexos mecanismos de controle de constitucionalidade e pelo vigor dos efeitos de suas decisões, em especial os efeitos erga omnes e vinculantes, somados à inércia dos Poderes Políticos em efetivar totalmente as normas constitucionais, vem permitindo que novas técnicas interpretativas ampliem a atuação jurisdicional em assuntos tradicionalmente de alçada dos Poderes Legislativo e Executivo. Principalmente, a possibilidade do Supremo Tribunal Federal em conceder interpretações conforme a Constituição, declarações de nulidade sem redução do texto, e, ainda, mais recentemente, a partir da edição da Emenda Constitucional $n^{\circ}$ 45/04, a autorização constitucional para editar, de ofício, Súmulas Vinculantes não só no tocante à vigência e eficácia do ordenamento jurídico, mas também em relação à sua interpretação, acabaram por permitir, não raras vezes, a transformação da Corte Suprema em verdadeiro legislador positivo ${ }^{116}$.

\footnotetext{
${ }^{115}$ BELLAMY, Richard. Constitucionalism and democracy/ edited by Richard Bellamy. Ashgate. 2006, p. 11.

${ }^{116}$ MORAES, Alexandre de. Direito Constitucional, 2012. p. 801.
} 
O Supremo Tribunal Federal no seu papel democrático é dotado de função social que consiste na proteção da Constituição Federal e seus valores, atuando como um poder moderador nas questões e debates de grande impacto social.

Decerto, a atuação ativista do STF não pode ser tida como um elemento permanente e sim como uma medida provisória, a fim de estabelecer equilíbrio institucional, em razão dos inúmeros escândalos de corrupção que vieram à tona nos últimos anos, fragilizando especificamente os poderes legislativo e Executivo, órgãos com maior incidência desses casos.

A postura ativista do Supremo Tribunal Federal dá margem para dois aspectos: o primeiro, é a simpática por essa postura, e o segundo é a apatia à esse tipo de prática. O Poder Judiciário brasileiro tornou-se a sede de debates e é o interprete de todo o conteúdo e dos valores das normas constitucionais. Se a Constituição é o reflexo do diversos interesses da sociedade que está sob sua iluminação, O STF age como o mediador dos princípios e valores dela.

É indubitável afirmar que o STF exerce papel democrático e de democratização dos seus julgamentos quando dá publicidade a eles por meio dos canais de comunicação pela TV Justiça ${ }^{117}$ e também por meio de seu canal no Youtube ${ }^{118}$. A transmissão dos julgamentos é ao vivo e em TV aberta. É possível acompanhar as deliberações e o debate entre os ministros e as sustentações orais, como também o veredicto pela leitura dos votos. A crítica à transmissão dos julgamentos defende que a publicidade prejudica a construção de consenso entre os ministros e os expõe à opinião pública, possibilitando a inadequada politização dos julgamentos. Dessarte, observa-se que é a leitura extensa dos votos, que em tese, tornam os julgamentos mais longos.

Entrementes, a publicidade dos julgamentos é positiva e possibilita que a sociedade acompanhe e participe das decisões que trarão impacto direto nas suas vidas, e ainda colabora para desmistificar a ideia de que no Brasil tudo é feito às escuras.

De tal sorte, o caráter democrático do Supremo Tribunal Federal é visto também na possibilidade que o relator do caso tem em convocar audiências públicas antes de decidir casos sensíveis. Nas audiências públicas entidades ou especialistas podem ser convidados para expor sua opinião diante do Tribunal. O amicus curiae e ampliação no rol de legitimados também são postulados da participação democrática no STF.

\footnotetext{
${ }^{117}$ Disponível em http://www.tvjustica.jus.br/

${ }^{118}$ Disponível em https://www.youtube.com/user/STF
} 
O STF também se reveste de caráter democrático pelo aspecto histórico nacional. Conforme abordado anteriormente, o Brasil fora marcado pela excepcionalidade do regime militar, que foi responsável pela ausência de participação democrática no País e cerceamento das liberdades e garantias individuais. Com o advento da Constituição Federal de 1988, viu-se inserida em seu contexto as mais variadas conquistas de diversos segmentos da sociedade.

Sob este prisma, urge destacar a observação feita por Jorge Octávio Lavocat Galvão:

Relativamente ao Brasil, no começo de sua experiência democrática, uma Corte Constitucional com amplos poderes fazia-se necessária para fortalecer o compromisso com os direitos fundamentais e aniquilar os espectros da ditadura. Vinte anos depois, entretanto, a população depara-se com a possibilidade de ter restringida sua participação na tomada de decisões político-sociais $^{119}$.

O conteúdo da Carta Magna contemplou uma amplitude de direitos, típicos de uma sociedade multifacetada. Diante disso, o clamor da população exigiu que as questões sociais, fossem resolvidas, não só pelos órgãos de representação, mas também por meio dos processos judiciais.

Nesse contexto, nota-se a eficiência que as decisões judiciais possuem no País, seja quando se garante um direito constitucionalmente previsto, bem como quando há notória omissão legislativa sobre determinado tema.

Analisando a crise de representatividade, observou-se que a participação da população na tomada de decisões políticas sofreu considerável afastamento. É nesse aspecto que há convergência entre a democracia e o ativismo judicial. Os representantes eleitos não atendem por completo os anseios da sociedade. A péssima qualidade política dos mandatários é fator determinante para uma ausência de efetiva representatividade democrática. Interesses corporativos e oligárquicos suplantam interesses coletivos e sociais. A má escolha política afeta no bom desenvolvimento e administração do poder público.

119 GALVÃO, Jorge Octávio Lavocat. Concentração de Poder da Jurisdição Constitucional: Uma análise crítica de seus pressupostos filosóficos. In: ALMEIDA, Fernando Dias Menezes de; AMARAL JÚNIOR, José Levi Mello do; LEAL, Roger Stiefelmann; HORBACH, Carlos Bastide (Coord.). Direito Constitucional, Estado de Direito e Democracia: Homenagem ao Prof. Manoel Gonçalves Ferreira Filho. São Paulo: Quartier Latin, 2011. p. 391. 
A grande controvérsia em torno da atuação do STF gira em torno da tomada de decisões acerca de temas sensíveis ou casos difíceis que afetam frontalmente toda a sociedade. Determinados temas tem sido decididos fora do debate político sem a participação dos representantes eleitos, havendo deslocamento para os tribunais, que passam a constituir um novo ambiente de discussão de questões de interesse da sociedade.

Quando se fala em deslocamento do debate político para o STF em especial, significa dizer que as discussões e os temas tem o aspecto constitucional envolvido, pois todo debate, seja ele político ou jurídico que tenha o viés constitucional, passará pela análise e controle do Poder Judiciário. Apesar disso, a crítica ao STF não fundamenta-se meramente em julgar assuntos de natureza constitucional, mas de haver uma postura excessiva nessa atuação, fazendo com que o Poder Legislativo seja um concorrente do Judiciário, pois este estaria, em tese, violando as atribuições exclusivas do Legislativo.

É importante destacar que a função do STF não deve sobrepor-se de nenhum modo à dos outros poderes, sob pena de se incorrer em usurpação das atribuições típicas das instituições republicanas. A atuação do STF é sim eficiente, mas também, deve respeitar os limites constitucionais a si impostos. Toda e qualquer prática que de algum modo invada a atribuição exclusiva de outro poder da república, deve ser excepcional e temporária e só poderia ser realizada por deficiência institucional.

Atualmente já é possível ver acenos do diálogo institucional, a fim de se evitar arbitrariedades de quaisquer autoridades envolvidas no jogo democrático.

Nesse sentido, destaca-se o pensamento de Humberto Ávila:

O Poder Judiciário não deve assumir, em qualquer matéria e em qualquer intensidade, a prevalência na determinação da solução entre conflitos morais porque, num Estado de Direito, vigente numa sociedade complexa e plural, deve haver regras gerais destinadas a estabilizar conflitos morais e reduzir a incerteza e a arbitrariedade decorrente de sua inexistência ou desconsideração, cabendo à sua edição ao Poder Legislativo e a sua aplicação, ao Judiciário $^{120}$.

\footnotetext{
120 ÁVILA, Humberto. "Neoconstitucionalismo": entre "Ciência do Direito" e o "Direito da Ciência". In: BINENBOJM, Gustavo; NETO, Cláudio Pereira de Souza; SARMENTO, Daniel (Coord.). Vinte Anos da Constituição Federal de 1988. Rio de Janeiro: Lumen Juris, 2009. p. 200.
} 
Sem dúvida, o Supremo Tribunal Federal tem sido protagonista de grandes temas e pautas políticas da nação, sendo que essas discussões deveriam ter sido tratadas no órgãos de legitimação democrática com a participação popular, o que não ocorreu. Ademais, a opinião pública tem de certa forma legitimado a atuação do STF, bem como suas decisões. A sociedade exige uma resposta de seus representantes, quando eles não dão, o STF preenche essa lacuna.

John Rawls entende que, há uma difusão de legitimidade entre os poderes Legislativo, Executivo e Judiciário, para o exercício daquilo que denomina de razão pública, nesse sentido, ele assevera:

A razão pública é a característica de um povo democrático: é a razão de seus cidadãos, daqueles que compartilham do status da cidadania igual. O objeto da razão dos cidadãos é o bem do público, aquilo que a concepção política de justiça requer da estrutura básica institucional da sociedade e os propósitos e fins a serviço dos quais tal estrutura deve se colocar ${ }^{121}$.

Neste aspecto, um tribunal de jurisdição constitucional, seria espaço dessa razão pública, incorporada a uma visão democrática e de separação de poderes, legitimando sua atuação às consequencias da razão pública, não limitando seu procedimento democrático, como também tornando sujeito das razões essenciais.

Para John Rawls, "ao aplicar a razão pública, o tribunal age para evitar que a lei seja erodida pela legislação de maiorias transitórias" ${ }^{122}$.

No processo democrático, o Supremo Tribunal Federal será o filtro para coibir a tirania da maioria, pois a ideia de supremacia do parlamento traz dificuldades sobre a crítica que se faz às suas decisões impossibilitando o diálogo entre os poderes. A democracia é constituída de diversidades.

Todavia, o posicionamento da população em relação à atuação do STF não é unânime, pois há uma parcela da sociedade que vem defendendo o fechamento do Supremo Tribunal Federal, colocando-o como vilão nacional e fazendo referências ao regime militar.

Com efeito, o papel do STF nem sempre consiste em ser ativista ou dar intepretação nova. A exemplo disso destaca-se o julgamento da ADI $3.510^{123}$ de

\footnotetext{
${ }^{121}$ RAWLS, John. O liberalismo político, 2011. p. 250-1

${ }^{122}$ Idem, ibidem. p. 276
} 
relatoria do ministro Carlos Ayres Britto que tratou da liberação das pesquisas com células-tronco. Segundo o entendimento do Supremo Tribunal Federal, as pesquisas com células-tronco embrionárias não violam o direito à vida, tampouco a dignidade da pessoa humana. Essa decisão também foi exemplar do ponto de vista democrático, nesse ponto transcrevemos a observação de Eber de Meira Ferreira:

\begin{abstract}
Sob o aspecto da participação popular, núcleo do postulado democrático, ainda que casos como o julgamento da ADI 3.510 tenham se mostrado exemplares do ponto de vista de uma maior abertura para a participação da sociedade no processo de formação da decisão final, certamente não se está diante de um locus deliberativo amplo, como seria em sua forma ideal uma casa legislativa, pelo menos na ótica da amplitude da participação popular ${ }^{124}$.
\end{abstract}

Há grupos que se valem das ações diretas para questionar direitos que visem propor políticas de ações afirmativas, a exemplo destaca-se o julgamento da ADI $3.330^{125}$, que discutiu a constitucionalidade do Programa Universidade Para Todos (PROUNI). O programa possibilitou a entrada de milhares de estudantes de baixa renda no ensino superior privado. O STF decidiu pela improcedência da ação, declarando que a lei 11.096/2005 era Constitucional. A lei do PROUNI veio ao encontro das necessidades sociais em que o País se encontrava. A dificuldade de acesso à educação superior foi minimizada, ante o extremo abismo de desigualdades que ainda assolam o Brasil. A ação direta de inconstitucionalidade 3.330 foi uma medida que tinha o fito de exterminar essa política pública educacional, mas a postura firme do STF foi relevante para defender os interesses da democracia, por certo que o Brasil, em relação aos demais países democráticos, lidera o ranking de concentração de riquezas ${ }^{126}$.

Nessa mesma linha, o STF também exerceu seu papel democrático ao julgar improcedente a ADPF $186^{127}$, que questionava se as cotas raciais constituíam um elemento legítimo e proporcional, apontando se o fator raça é critério discriminador para possibilitar reserva de vagas em $20 \%$, alegando ainda por que as ações afirmativas

\footnotetext{
${ }^{123}$ Supremo Tribunal Federal. ADI n. 3510/DF. Relatoria do Ministro Carlos Ayres Brito. Julgamento 29.05.2008

${ }^{124}$ FERREIRA, Eber de Meira. Poder judiciário, ativismo judicial e democracia. 2014. p. 119.

125 Supremo Tribunal Federal. ADI n. 3330/DF. Relatoria do Ministro Carlos Ayres Brito. Julgamento 03.05.2012

${ }^{126}$ Disponível em https://temas.folha.uol.com.br/desigualdade-global/brasil/super-ricos-no-brasil-lideramconcentracao-de-renda-global.shtml acesso em 20.01.2020

127 Supremo Tribunal Federal. ADPF n. 186/DF. Relatoria do Ministro Ricardo Lewandowski. Julgamento 26.04.2012
} 
não contemplavam outros grupos considerados minoritários. Para corrigir desigualdades étnico-raciais é que se decidiu pela improcedência da ação. O critério de julgamento do Tribunal se baseou na intepretação sistêmica e principiológica da Constituição, a fim de equilibrar os objetivos constitucionais. A reserva de vagas contemplava negros e indígenas, e a medida tinha prazo determinado de 10 anos.

Mostra-se que, o Supremo Tribunal Federal, também agiu democraticamente, de modo a proteger as novas relações de trabalho ao decidir pela procedência da ADPF $449^{128}$, que fora ajuizada em face da lei 10.553/2016 de Fortaleza (CE) que proibia o uso de carros particulares, cadastrados ou não em aplicativos, para o transporte remunerado individual de pessoas e prevê multa de $\mathrm{R} \$ 1.400$ ao condutor do veículo.

A lei municipal foi declarada inconstitucional, sob o fundamento de que ela violava os princípios da livre iniciativa, do valor social do trabalho, da livre concorrência, da liberdade profissional, além da proteção ao consumidor. Os motoristas de aplicativo vêm encontrando dificuldades com o excesso de regulamentação local das cidades, mas o entendimento do STF foi no sentido de que o motorista particular é protegido pela liberdade fundamental e se submete apenas à regulação definida em lei federal. E, no caso, o Marco Civil da Internet (Lei 12.965/2014) e a Política Nacional de Mobilidade Urbana (Lei 12.587/2012) garantem a operação de serviços remunerados de transporte de passageiros por aplicativos.

Por mais criticado que seja, o STF tem agido de modo a concretizar os direitos e garantias fundamentais, e tem sido responsável por equilibrar o jogo democrático protegendo o cidadão dos abusos do poder público e da atuação ineficaz do Legislativo, e até mesmo os partidos políticos de representação nacional buscam decisões do Supremo para invalidar leis ou atos normativos de outros partidos que se consideram de oposição ou que vá contra seus interesses, ou até mesmo contra outro órgão de poder da república $^{129}$.

Nesse sentido, o Supremo Tribunal Federal, a fim de estabelecer justiça e paridade de armas, vem exercendo, além do papel democrático, a função contramajoritária.

\footnotetext{
${ }^{128}$ Supremo Tribunal Federal. ADPF n. 449/DF. Relatoria do Ministro Luiz Fux. Julgamento 08.05.2019

${ }^{129}$ Em 2019, partidos foram mais ativos do que a própria PGR em ações no STF. Siglas ingressaram com $27 \%$ das ações questionando leis e normas na mais alta Corte do país. Disponível em https://oglobo.globo.com/brasil/em-2019-partidos-foram-mais-ativos-do-que-propria-pgr-em-acoes-nostf-24171369. Acesso em 21.01.2020
} 


\subsection{A Função Contramajoritária do STF}

A função contramajoritária do Supremo Tribunal Federal consiste na invalidação de leis e atos normativos dos poderes Executivo e Legislativo.

Como observado, composição dos ministros do STF não se dá por eleição, mas por nomeação política. A possibilidade de juízes não eleitos se valerem da sua interpretação constitucional para invalidar atos de agentes públicos, cuja legitimidade foi dada pelo voto da maioria, é denominada de dificuldade contramajoritária. Ao atuarem em nome da Constituição, os ministros do STF possuem a legitimidade para garantir a proteção dos direitos e garantias fundamentais e equilibrar o sistema democrático, mesmo que isso seja contra a vontade das maiorias. Como a Constituição Federal de 1988 é extremamente abrangente, num sistema democrático, muitas matérias são deixadas para as leis infraconstitucionais tratarem ou regulamentarem, o que é realizado pelos representantes eleitos com os votos da maioria.

Todavia, as matérias tratadas pelas leis infraconstitucionais se revelam insuficientes na sua aplicabilidade, o que faz com que se discutam essas matérias pela via judicial perante o Supremo Tribunal Federal, que tratará de suprir as questões que foram deixadas de lado pelo debate político. Certamente, o STF terá a função de ampliar o debate, tornando-o mais democrático, no sentido de que o Legislativo não atendeu a essa expectativa. Por haver temas que são omissos ou tratados de modo frágil pelos órgãos de representação, é que o STF representará democraticamente os interesses da maioria e também das minorias no debate político pátrio.

Vale dizer que o direito é dinâmico. Suas mudanças são constantes. Pensamentos teóricos surgem, a fim de facilitar a vida de modo geral. Não obstante o direito ser dinâmico, a democracia também o é, por tal razão que há discussões ilimitadas sobre o binômio constitucionalismo/ democracia.

A dificuldade contramajoritária é um debate que vem sendo travado ao longo de anos e certamente continuará. A revisão judicial por meio do controle judicial de constitucionalidade é o meio hábil da função contramajoritária. O próprio sistema constitucional pátrio admite em seu contexto que juízes não eleitos pela população possam tornar inválidas as leis elaboradas pelos órgãos representativos.

Como a sociedade é dinâmica e consciente, há o clamor público para que o poder público funcione e seja efetivo, e uma atitude meramente passiva não proporcionará mudanças significativas. O voto periódico em anos eleitorais não se 
revela suficiente para que direitos fundamentais sejam concretizados. O cidadão não pode restringir sua participação política democrática, sendo meramente um eleitor, esperando pacientemente e confiando em seus representantes para realizar as mudanças necessárias com o fim de promover um Estado seja eficiente. Ademais, a democracia não envolve apenas aspectos eleitorais, mas também uma participação constante dos atores sociais.

A democracia deve atender aos anseios da sociedade, seja por meio dos representantes eleitos, seja na efetivação das políticas públicas. Deve haver um liame comunicativo entre os órgãos de representação e a sociedade.

Muitos grupos da sociedade se aguardassem uma deliberação do Poder Legislativo para satisfazer um direito ou obter política pública, certamente seriam vencidos pela espera infindável. A exemplo disso como mencionado anteriormente destaca-se a ADPF 132, que reconheceu como entidade familiar a união homoafetiva. É certo que se esses grupos considerados minoritários aguardassem a elaboração de lei que regulamentasse a matéria, ficariam a mercê de seus direitos e não teriam segurança jurídica, posto isso foi necessário recorrer ao STF para que isso não ocorresse.

Por trás desse debate que envolve constitucionalismo e democracia, têm-se o que se denomina de dificuldade contramajoritária, expressão tornada clássica por Alexander Bickel ${ }^{130}$.

A crítica que se faz ao papel contramajoritário entende que o controle judicial de constitucionalidade levou ao protagonismo do Poder Judiciário conduzindo o sistema à denominada supremacia judicial.

Destacando o exemplo que ocorre nos Estados Unidos acerca do chamado dilema de Madison, Sérgio Antônio Ferreira Victor assevera:

Os Estados Unidos teriam sido fundados nos molde de um sistema proposto por James Madison, o qual se assenta na necessidade permanente de reconciliação entre dois princípios opostos. O primeiro seria o direito ao autogoverno, que significa que a maioria tem direito a governar, simplesmente por uma questão numérica: a opinião do maior número de pessoas deve prevalecer. O segundo princípio, oposto ao primeiro, é que há algumas medidas que a maioria não pode adotar por serem ofensivas aos direitos das minorias: em algumas áreas, os indivíduos devem ser livres, não devem ser coagidos pela vontade da maioria. O dilema de Madison, segundo

\footnotetext{
${ }^{130}$ BICKEL, Alexander M. The last dangerous branch: the Supreme Court at the bar of politics, 1986.
} 
Bork, está em que não se deve confiar à maioria, tampouco à minoria, o poder para definir limites entre a autoridade democrática (regra da maioria) e a liberdade individual, pois existe sempre o risco de uma tirania, seja ela da maioria, seja da minoria ${ }^{131}$.

Entendemos que defender a minoria, de um modo geral, é equilibrar o jogo democrático para não gerar tirania. Posto isso, haveria muito mais uma tirania da maioria do que a de uma minoria, provavelmente porque os pequenos grupos da sociedade absorvem proporcionalmente, muito mais, os interesses da maioria vigorosa, do que o inverso.

O sistema jurisdicional constitucional foi elaborado para que pudesse reconciliar o governo da maioria com os interesses das minorias, nesse sentido, Robert Bork salienta que a Constituição neutraliza essas controvérsias de três formas, "limitando os poderes do governo federal, organizando que o Presidente, os senadores e os representantes sejam eleitos por diferentes eleitorados que votem em momentos diferentes e fornecendo uma Declaração de Direitos" ${ }^{132}$.

A crítica de Alexander Bickel baseia-se na constatação de que o controle de constitucionalidade ou "judicial review" é uma instituição não democrática e seu modo de utilização seria injustificado num modelo em que prevalece a legitimidade do governo da maioria.

Obviamente que as ponderações de Bickel são realizadas pela perspectiva norte americana, tendo um contexto diverso do brasileiro. Em nosso contexto, o controle de constitucionalidade de leis e atos normativos, deve-se em razão da evolução constitucional, bem como pelas limitações sofridas pela judiciário, ao longo do regime de exceção no país. O Poder Judiciário não é visto mais como o poder mais fraco, mas agora passa a ter um papel relevante no contexto político pátrio, haja vista que a própria Constituição Federal de 1988 ampliou a atividade judicante, justamente para resguardar o país de uma possível instabilidade democrática.

Dissertando sobre o posicionamento de Alexander Bickel, Arnaldo Sampaio de Moraes Godoy aponta:

\footnotetext{
131 Op.cit. p. $102-103$

132 BORK, Robert H. The Temping of America: The political seduction of the law. New York: First Touchstone Edition, 1991, p.139. In VICTOR, Sérgio Antônio Ferreira. op.cit. p. 103.
} 
Bickel revelou-se como rigoroso crítico do ativismo judicial. Concebia a política como uma projeção da maioria. O governo deveria pautar suas ações no contexto desse majoritarismo, absolutamente refletido no Executivo e no Legislativo. O Judiciário desequilibrava o jogo democrático, na visão de Bickel, que denunciava o contramajoritarismo; para Bickel, o papel da magistratura assemelhava-se à desobediência civil, tema recorrente nos Estados Unidos nas décadas de 1950 e $1960^{133}$.

Entretanto, como enxerga-se na história, na cultura e na sociedade, os problemas da democracia não se resumem ao controle de constitucionalidade, utilizado como mecanismo do ativismo judicial. Os processos democráticos sofrem de avanços e retrocessos simultaneamente e urge a necessidade de maior democratização na sociedade.

Como ressaltado, as práticas de ativismo judicial não devem ser realizadas de modo permanente, mas temporariamente e para suprir de modo limitado as lacunas deixadas pelos órgãos de representação.

Quando verifica-se falhas no processo democrático ou representativo, é que aparecem os denominados grupos de pressão, cuja existência baseia-se na reinvindicação assídua contra o governo para impugnar atos que sejam considerados levianos ou violadores das prerrogativas da sociedade. Esses grupos de pressão, em certa medida, exercem influência muito mais notória do que os eleitores, que denominamos de passivos.

Os grupos constituem um aglomerado de pessoas que tenham interesses, objetivos e ideologias em comum, a fim de se organizarem nas exigências de suas pautas específicas.

Sobre a expressão grupo social, Alexandre Sanson se pronuncia:

O grupo social é aquele que abarca uma pluralidade de indivíduos (díade no mínimo), os quais se tornam um todo, em decorrência das ações/reações mútuas e de vestígios de organização, com semelhanças de atitudes e sensações (consenso/in-group) - comportando agir coletivo (consciência) -, apresentando, ainda, finalidades intencionais, orientadoras da sua conduta única, coordenada ou coincidente, e constituintes da sua estrutura autônoma, a qual os distingue de agrupamentos amorfos. Ademais, internamente, é

${ }^{133}$ GODOY, Arnaldo Sampaio de Moraes. Alexander Bickel e a metáfora do Judiciário como o mais fraco dos poderes, 2014. Disponível em https://www.conjur.com.br/2014-ago-03/embargos-culturaisalexander-bickel-metafora-judiciario-fraco-poderes. Acesso em 23.01.2014 
definidor do status ou papel dos seus integrantes, solidariamente responsáveis pelos resultados, fixando-lhes normas objetivas de procedimento (disciplina), de conformidade com a sua estratégia/tática de ação, num dado contexto, incorrendo, desse modo, em relação social diferenciada, pois não se confunde com unidades singularmente físicas (e.g. reunião instintiva), espirituais (e.g. mesma ideologia/fé) ou psíquico-internas (e.g. desejos e intenções em interações desordenadas e episódicas) ${ }^{134}$.

A sociedade multifacetada é composta por pessoas que se organizam de todo os modos, posto que, todo grupo de pressão é um grupo de interesse, tendo enfoque precipuamente político nas suas reinvindicações se engajando no processo decisório governamental.

Alguns grupos obtém mais proeminência do que outros nos procedimentos decisórios e na participação política, daí surge o lobby, que se fundamenta na estrita relação entre público e privado, social e institucional. É o grupo que exerce influência sobre os agentes estatais para alcançar seus propósitos.

Como se nota, há extrema concentração de poder, o que possibilita que o elemento contramajoritário surja num ambiente democrático, posto que a pretensão de setores da sociedade não podem ser ignoradas, com isto, a crescente politização e profissionalização dos indivíduos possibilitará que consigam alcançar o Poder Judiciário como órgão de representação.

Acerca do pluralismo numa sociedade democrática, transcrevemos a lição de Norberto Bobbio:

O termo é novo, mas o conceito não. Que uma sociedade é tanto melhor governada quanto mais repartido for o poder e mais numerosos forem os centros de poder que controlam os órgãos do poder estatal é uma ideia que se encontra em toda a história do pensamento político. Umas das formas tradicionais para distinguir um governo despótico de um governo não despótico é observar a maior ou menor presença dos chamados corpos intermediários e, mais precisamente, a maior ou menor distribuição de poder territorial e funcional entre governantes e governados. A alta concentração de poder não tolera a formação de poderes secundários e interpostos entre o

${ }^{134}$ SANSON, Alexandre. Dos grupos de pressão na democracia representativa: os limites jurídicos, 2013. p. 84 
poder central e o indivíduo, e que anula toda a oposição ao arbítrio do governante, caracteriza essencialmente todo governo despótico ${ }^{135}$.

A alternância de poder é comum e necessária, mas toda alternância exige a existência de uma oposição capaz de estabilizar as decisões políticas. No País o ambiente democrático precisa ser harmonizado por meio do diálogo, para que toda a população em todos os seus seguimentos encontrem segurança jurídica.

O protagonismo do Judiciário vem sendo acompanhado por vários setores da sociedade, pesquisadores, jornalistas, mídias em geral etc. Nota-se que vem ocorrendo uma transferência de poder das esferas representativas para o ambiente dos tribunais, e esse fenômeno se deu em escala mundial tendo como ponto de partida o fim da segunda guerra mundial, que representou um fim de um ciclo em direção para um novo, o processo de redemocratização.

As transferências de poder se encontram na elaboração de Constituições, pelo aumento do acesso à justiça e por meio dos tratados internacionais. A revisão constitucional de leis e atos normativos elaborados pelos órgãos representativos, representou uma reconfiguração da democracia representativa

Quando a Constituição Federal representa a vontade do todo o povo, ela deve ser protegida diante das decisões políticas que a viole, pois assim estar-se-ia violando a vontade de toda a sociedade. Preservar a Constituição de dispositivos inconstitucionais é exercício de uma função contramajoritária e democrática.

Sobre o fortalecimento da democracia e o papel do Poder Judiciário, Thamy Pogrebinschi disserta:

Uma das formas possíveis de fortalecimento da democracia representativa pode encontrar-se no crescimento do papel das cortes constitucionais. Ao contrário de esvaziar o Poder Legislativo em sua função institucional ou de valer-se de um suposto vazio normativo por ele deixado, a fim de desenvolverem-se, as cortes constitucionais podem ser tomadas como propulsoras da representação política, ampliando-a para além de sua forma moderna e de suas manifestações tradicionais. Em outras palavras, o crescente papel institucional das cortes constitucionais poder ser concebido não como ameaça à representação, às instituições representativas ou à

\footnotetext{
${ }^{135}$ BOBBIO, Norberto. As ideologias e o poder em crise, democracia, socialismo, comunismo, terceira
} via e terceira força, 1994. p. 15. 
democracia; mas, ao contrário, como um sinal de que a primeira precisar ser ressignificada, as segundas reconfiguradas e a terceira fortalecida ${ }^{136}$.

Nesse sentido, a noção de representação política é ampliada, pois ao STF cabe fortalecer os aspectos democráticos, aperfeiçoando, então, o trabalho do Poder Legislativo, mesmo que haja declaração de inconstitucionalidade parcial ou total, posto que moverá os órgãos representativos em direção ao bom funcionamento do sistema.

Para Thamy Pogrebinschi ${ }^{137}$ a ampliação do conceito de representação política é necessária, visto que responderia de modo mais preciso aos entraves corriqueiros no sistema eleitoral e nos partidos políticos, em razão das divergências travadas pela atuação de agentes não eleitos que interferem nas atribuições daqueles que estão inseridos no modelo majoritário.

O Supremo Tribunal Federal deve servir de representante para aqueles grupos considerados como minorias culturais e não meramente políticas. Nesse sentido, Assevera Thamy Pogrebinschi:

\begin{abstract}
(...) o caráter não majoritário das cortes constitucionais pode se revelar propício para produzir uma representação propriamente política (e não meramente judicial) de minorias culturais que não necessariamente sejam também minorias políticas. Nesse sentido, os grupos historicamente marginalizados, a despeito de buscarem a representação de seus interesses nos órgãos legislativos, deveriam buscá-la prioritariamente nos órgãos judiciais - em particular nas cortes constitucionais que, em sua função de salvaguardar os direitos sociais e culturais constitucionalmente assegurados, podem atuar, no exercício de seu papel institucional contramajoritário, como uma instância pró-minoritária ${ }^{138}$.
\end{abstract}

A representação política não deve ser vista apenas sob o prisma dos agentes eleitos, mas deve também ser enxergada sob a ótica daqueles que possuem legitimidade para agir em nome do interesse público, com isto, o Supremo Tribunal Federal tem legitimidade para atender os interesses da sociedade outorgados pela Constituição Federal de 1988.

\footnotetext{
${ }^{136}$ POGREBINSCHI, Thamy. Judicialização ou representação: política, direito e democracia no Brasil, 2011. p. 165

${ }^{137}$ POGREBINSCHI, Thamy. Op. cit. p. 167.

${ }^{138}$ Ibidem, p. 174
} 
Um ponto importante a ser considerado é que a representação política é fortalecida quando as instituições são protegidas, dando sustentação para a democracia. Entrementes, o ativismo judicial e a judicialização das políticas públicas não constituem por si só numa violação aos aspectos representativos, pelo contrário, o que de fato afeta o modelo representativo é justamente a ausência de representação. É a não representatividade que constitui risco para o processo de democratização da sociedade.

Desse modo, a democracia traduz-se num objeto dinâmico em que as instituições são responsáveis por mantê-la, quando uma ou mais delas não estiver desempenhando seu papel de maneira eficiente, caberá a um dos poderes da república supri-lo. Por conseguinte, a esperança nas instituições não deve ser nunca perdida, mas deve haver colaboração mútua e o fomento ao diálogo entre os órgãos para que o equilíbrio e o cumprimento das diretrizes constitucionais sejam obedecidos. 


\section{CONCLUSÃO}

O Estado, no decurso do tempo, foi moldado de acordo com os anseios sociais, e verificou-se a necessidade do estabelecimento de mecanismos de participação popular, a fim de que houvesse maior distribuição de poder.

A democracia, como a melhor forma de governo, constitui-se mecanismo hábil para promover o justo equilíbrio entre as instituições e servir de mediadora das relações entre o governo e os cidadãos.

O povo passa a ser o soberano nas decisões coletivas no que diz respeito ao poder político, e de todo o modo, a democracia é o melhor sistema para corrigir as distorções arbitrarias advindas dos regimes totalitários.

A democracia é necessária, e não deve se limitar apenas no exercício do sufrágio universal. Limitar o exercício da cidadania e a conquista de direitos ao voto é tornar as conquistas populares diminutas. A participação popular precisa ser direta e efetiva. O cumprimento dos direitos e garantias fundamentais faz parte da democracia.

As instituições democráticas constituem um conjunto de equilíbrio, a fim de estabelecer uma ordem justa e igualitária.

Nota-se que, em certa medida os órgãos representativos não conseguem atender por inteiro a todas as demandas e anseios da sociedade. Os representantes eleitos, por serem autônomos no mandato eletivo, muitas vezes acabam por atender seus próprios interesses, já que não há vinculação deles com seus eleitores.

Diante disso, é presente no contexto pátrio a insuficiência de representatividade, que surge no momento em que a vontade soberana da população é desperdiçada e não atendida em virtude de interesses oligárquicos.

Sabe-se que ao Estado cabe assegurar a todos os direitos constitucionais, direitos e garantias fundamentais, todavia, quando estes não são concedidos por meio dos instrumentos democráticos legítimos, é que aparece a atuação do poder Judiciário.

O Supremo Tribunal Federal serve de poder moderador num Estado Democrático de Direito, como é o Brasil. E se vale das práticas de ativismo judicial e da judicialização das políticas públicas para suprir as lacunas deixadas pelo poder público.

Cabe à Suprema Corte defender e ser guardião da Constituição, além de, quando provocado, garantir que o poder público atenda aos princípios republicanos. Deste modo, ao verificar-se que o poder público, no que tange ao poder Legislativo e Executivo restam inertes na concretização dos direitos e garantias fundamentais. Neste 
aspecto é que o STF atua de modo democrático, representativo e contramajoritário para que as políticas públicas e direitos constitucionais sejam alcançados.

Apesar das criticas e acusações, o Supremo Tribunal Federal tem desempenhado uma atividade representativa, assegurando que determinados grupos ou setores da sociedade, sejam protegidos da tirania da maioria.

Porquanto, o Supremo Tribunal Federal torna-se o representante democrático, daqueles que não encontram voz no Congresso Nacional, dado que ele estabelece o equilíbrio entre as ações e omissões dos poderes da república.

Naturalmente, os direitos fundamentais $\mathrm{e}$ as políticas públicas são negligenciados em relação à necessidade dos cidadãos, forçando-os a se valer de mecanismos processuais constitucionais para obter estes direitos.

Essa atuação do Supremo Tribunal Federal é encarada como ativismo judicial, ou seja, entende-se que ele ultrapassa suas competências, invadindo competências exclusivas dos outros poderes para a efetivação dos direitos constitucionais.

Portanto, conclui-se que a democracia não se resume apenas no exercício do voto e na escolha de representantes eleitos, mas, sobretudo, na conquista da efetiva participação popular nas decisões políticas. Posto isto é a atuação do Supremo Tribunal Federal tem sido fundamental para coibir lesão aos direitos fundamentais, proporcionando um exercício pleno do poder político da sociedade. 


\section{REFERÊNCIAS}

AMARAL JÚNIOR, José Levi Mello do. Sobre a organização de poderes em Montesquieu: Comentários ao Capítulo VI do Livro XI de "O espírito das leis", 2008. Disponível em: https://edisciplinas.usp.br/ - Acesso em 17.09.19.

ANDREUCCI, Álvaro Gonçalves Antunes. Fronteiras entre a eficiência jurídica e a censura: estudos sobre o Supremo Tribunal Federal e a ditadura / Álvaro Gonçalves Antunes Andreucci, organizador. - São Paulo: Universidade Nove de Julho, UNINOVE, 2016.

AUGUSTO, Luís Gustavo Henrique. Participação social no processo legislativo federal: um estudo da Comissão de Legislação Participativa (CLP), da Comissão de Direitos Humanos e Legislação Participativa $(\mathrm{CDH})$ e da iniciativa popular de lei. Dissertação (Mestrado em Direito) - FGV - Fundação Getúlio Vargas, São Paulo, 2015. Disponível em http://bibliotecadigital.fgv.br/dspace/handle/10438/13706?show=full Acesso em 23.08.19

ÁVILA, Humberto. "Neoconstitucionalismo": entre "Ciência do Direito" e o "Direito da Ciência”. In: BINENBOJM, Gustavo; NETO, Cláudio Pereira de Souza; SARMENTO, Daniel (Coord.). Vinte Anos da Constituição Federal de 1988. Rio de Janeiro: Lumen Juris, 2009.

AZAMBUJA, Darcy. Teoria Geral do Estado/ Darcy Azambuja. - 42. ed. São Paulo: Globo, 2001.

BARROSO, Luís Roberto. Direito e política: a tênue fronteira ou judicialização, ativismo judicial e democracia. 2012. Disponível em: http://www.migalhas.com.br/dePeso/16,MI156926,41046-

Direito+e+politica+a+tenue+fronteira+ou+judicializacao+ativismo acesso em 18.09.19.

BARROSO, Luís Roberto. Neoconstitucionalismo e constitucionalização do Direito (O triunfo tardio do direito constitucional no Brasil). Revista de Direito Administrativo, Rio de Janeiro, v. 240, p. 1-42, abr. 2005. ISSN 2238-5177. Disponível em: <http://bibliotecadigital.fgv.br/ojs/index.php/rda/article/view/43618/44695>. Acesso em: 01 Out. 2019. doi:http://dx.doi.org/10.12660/rda.v240.2005.43618.

BARROSO, Luís Roberto. O Controle de Constitucionalidade no Direito Brasileiro. São Paulo: Saraiva, 2011.

BELLAMY, Richard. Constitucionalism and democracy/ edited by Richard Bellamy. Ashgate. 2006.

BICKEL, Alexander M. The last dangerous branch: the Supreme Court at the bar of politics. 2. ed. With a new foreword by Harry Wellington. New Haven and London: Yale University Press, 1986.

BOBBIO, Norberto, 1909. A era dos direitos/Norberto Bobbio; tradução de Carlos Nelson Coutinho. - Rio de Janeiro: Campus, 1992. 
BOBBIO, Norberto. As ideologias e o poder em crise, democracia, socialismo, comunismo, terceira via e terceira força/ Norberto Bobbio; tradução de João Ferreira; revisão técnica Gilson César Cardoso. - Brasília: Editora Universidade de Brasília, $3^{\text {a }}$ ed. 1994.

BOBBIO, Norberto. Estado, governo, sociedade; para uma teoria geral da polítical Norberto Bobbio; tradução Marco Aurélio Nogueira. -. Rio de Janeiro: Paz e Terra, 1987.

BORK, Robert H. The Temping of America: The political seduction of the law. New York: FirsT Touchstone Edition, 1991.

BONAVIDES, Paulo. A evolução constitucional do Brasil. Revista Estudos Avançados. São Paulo, 2000.

BONAVIDES, Paulo, Paes de Andrade. História Constitucional do Brasil. Rio de Janeiro: Paz e Terra, 1991.

BRANCO, Paulo Gustavo Gonet. Em busca de um conceito fugidio - o ativismo judicial. Texto não publicado, 2011.

BRASIL. Constituição Federal de 1988, 1988. Disponível em http://www.planalto.gov.br/ccivil 03/constituicao/constituicao.htm Acesso em 23.08.19

BRASIL. Código Civil. Lei $n^{o}$ 10.406, de 10 de Janeiro de 2002. Disponível em http://www.planalto.gov.br/ccivil_03/leis/2002/110406.htm Acesso em 03.09.19

BRASIL. Constituição Política do Império do Brasil de 1824. Disponível em http://www.planalto.gov.br/ccivil_03/Constituicao/Constituicao24.htm. Acesso em $\underline{17.09 .19}$

BRASIL. Constituição dos Estados Unidos do Brasil de 1937. Disponível em http://www.planalto.gov.br/ccivil_03/Constituicao/Constituicao37.htm. Acesso em 18. $\underline{09.19}$

BRASIL. Supremo Tribunal Federal. ADI n³510, Plenário do Supremo Tribunal Federal. Voto do Ministro Gilmar Mendes. Brasília, DF, 29 de maio de 2008. Disponível em: http://www.stf.jus.br/arquivo/cms/noticiaNoticiaStf/anexo/ADI3510GM.pdf. Acesso em 19.09.2019

CARDOSO, Fernando Henrique. A democracia necessária / Fernando Henrique Cardoso. - Campinas: Papirus, 1985.

CARVALHO, Ernani Rodrigues. Em busca da judicialização da política no Brasil: apontamentos para uma nova abordagem. Rev. Sociol. Polit [online]. Novembro, 2004. 
COLARES, Maria Lucia Fialho. Jurisdição Constitucional. Revista Pensar/Fortaleza/V. 4/N ${ }^{\circ}$ 4/P.134-150/JAN. $1996 . \quad$ Disponível em http://periodicos.unifor.br/rpen/article/view/2190. Acesso 07.10.19.

COSTA, Luciana da Silva. A revisitação do princípio da separação de poderes: dialogicidade e tensão como elementos conformadores da identidade constitucional brasileira. 2014. Tese (Doutorado em Direito do Estado) - Faculdade de Direito, Universidade de São Paulo, São Paulo, 2014. doi:10.11606/T.2.2014.tde-21012015091338. Acesso em: 2019-09-17.

DALLARI. Dalmo de Abreu, 1931. Elementos de Teoria Geral do Estado/ Dalmo de Abreu Dallari. - 24.ed. - São Paulo: Saraiva, 2003. p. 300.

DAMÉ, Luiza. Empresários e profissionais liberais são maioria na nova Câmara Repórter da Agência Brasil Brasília. Publicado em 12.10.2018. Disponível em http://agenciabrasil.ebc.com.br/politica/noticia/2018-10/empresarios-e-profissionaisliberais-sao-maioria-na-nova-camara. Acesso em 07.10.19.

FERREIRA, Eber de Meira. Poder Judiciário, ativismo judicial e democracia. 2014. Dissertação (Mestrado em Direito do Estado) - Faculdade de Direito, Universidade de São Paulo, São Paulo, 2014. doi:10.11606/D.2.2014.tde-08122014-161522. Acesso em: 2019-09-18.

FERREIRA FILHO, Manoel Gonçalves. Notas sobre o direito constitucional pósmoderno, em particular sobre certo neoconstitucionalismo à brasileira. Revista de Direito Administrativo, Rio de Janeiro, v. 250, p. 151-167, jan. 2009. ISSN 2238-5177. Disponível em: <http://bibliotecadigital.fgv.br/ojs/index.php/rda/article/view/4141>. Acesso em: 18 Set. 2019. doi:http://dx.doi.org/10.12660/rda.v250.2009.4141.

FILOMENO, José Geraldo Brito. Manual de Teoria Geral do Estado e Ciência Política/ José Geraldo Brito Filomeno. - 5. Ed. - Rio de Janeiro: Forense Universitária, 2003.

GALVÃO, Jorge Octávio Lavocat. Concentração de Poder da Jurisdição Constitucional: Uma análise crítica de seus pressupostos filosóficos. In: ALMEIDA, Fernando Dias Menezes de; AMARAL JÚNIOR, José Levi Mello do; LEAL, Roger Stiefelmann; HORBACH, Carlos Bastide (Coord.). Direito Constitucional, Estado de Direito e Democracia: Homenagem ao Prof. Manoel Gonçalves Ferreira Filho. São Paulo: Quartier Latin, 2011.

GARAPON, Antonie. O Juiz e a Democracia - o guardião das promessas. Rio de Janeiro: Editora Renavam, 1999.

GODOY, Arnaldo Sampaio de Moraes. Alexander Bickel e a metáfora do Judiciário como o mais fraco dos poderes, 2014. Disponível em https://www.conjur.com.br/2014ago-03/embargos-culturais-alexander-bickel-metafora-judiciario-fraco-poderes. Acesso em 23.01.2014 
HORBACH, Carlos Bastide. A nova roupa do direito constitucional: neoconstitucionalismo, pós-positivismo e outros modismos Revista dos Tribunais | vol. 859/2007 | p. 81 - 91 | Mai / 2007 DTR\2007\339.

KELSEN, Hans. A Garantia Jurisdicional da Constituição (A Justiça Constitucional). DIREITO PÚBLICO No 1 - Jul-Ago-Set/2003 - DOUTRINA ESTRANGEIRA. Disponível em https://www.portaldeperiodicos.idp.edu.br/direitopublico/article/view/1401. Acesso em 07.10.19.

LEAL, Roger Stiefelmann. O efeito vinculante na jurisdição constitucional. São Paulo: Saraiva, 2006.

LENZA, Pedro. Direito Constitucional Esquematizado. 16.ed. ver., atual. E ampl. - São Paulo: Saraiva, 2012.

LULIA, Luciana de Toledo Temer. PELLICCIARI, Natalia Rosa. Uma reflexão sobre a judicialização das políticas públicas com base na questão das cotas sociais e raciais. Revista de Direito Constitucional e Internacional, vol.97. 2016. Disponível em http://www.mpsp.mp.br/portal/page/portal/documentacao_e_divulgacao/doc_biblioteca/ bibli_servicos_produtos/bibli_boletim/bibli_bol_2006/RDConsInter_n.97.07_1.PDF Acesso em 14.10.19.

MENDES, Conrado Hubner. Direitos fundamentais, separação de poderes $e$ deliberação. 2008. Tese (Doutorado em Ciência Política) - Faculdade de Filosofia, Letras e Ciências Humanas, Universidade de São Paulo, São Paulo, 2008. doi:10.11606/T.8.2008.tde-05122008-162952. Acesso em: 2019-09-18.

MENDES, Conrado Hubner. Entrevista à Revista CAASP, 36 a edição. Agosto de 2018. p.7-8.

MENDES, Gilmar Ferreira. A evolução do direito constitucional brasileiro e o controle de constitucionalidade da lei. Revista de informação legislativa, v. 32, n. 126, p. 87102, abr./jun. 1995 | ADV Advocacia dinâmica : seleções jurídicas, n. 6, p. 15-27, jun. 1995. Disponível em http://www2.senado.leg.br/bdsf/item/id/176316, acesso 07.10.19.

MIARELLI, Mayra Marinho. Ativismo Judicial e a efetivação de direitos no Supremo Tribunal Federal/ Mayra Martinho Miarelli, Rogério Montai de Lima. - Porto Alegre: Sérgio Antônio Fabris Ed., 2012.

MONTEIRO, Jorge Vianna. Escolhas públicas de má qualidade e democracia representativa. Rev. Adm. Pública, Rio de Janeiro, v. 41, n. 4, p. 787-796, Agosto de 2007. Disponível em <http://www.scielo.br/scielo.php?script=sci_arttext\&pid=S003476122007000400008\&lng=en\&nrm=iso $>$. Acesso em 05 setembro de 2019. http://dx.doi.org/10.1590/S0034-76122007000400008.

MONTESQUIEU, Charles Louis de Secondat, baron de la Brède et de. De l'esprit deslois, vol. I, Paris: Garnier-Flammarion, 2005. O espírito das leis, tradução de Fernando Henrique Cardoso e Leôncio Martins Rodrigues, Brasília: UnB, 1995. 
MORAES, Alexandre de. Direito Constitucional. 28ª ed. São Paulo: Atlas, 2012.

OBRACAJ, Jan. La despolitización de la legitimación. Democracia entre sustitución y deliberación. p. 338 In GARDELLA, M. Mercè Darnaculleta i. PARDO, José Esteve. DOHMANN, Indra Spiecker Gen. Estrategias del derecho ante la incertidumbre y la globalización. Marcial Pons Ediciones Jurídicas y Sociales, S.A. Madrid, 2015.

PAES, Sara Maria Ströher. Sistema brasileiro de controle da constitucionalidade: origem e evolução. Revista de informação legislativa, v. 30, n. 118, p. 139-156, abr./jun. 1993. Disponível em http://www2.senado.leg.br/bdsf/handle/id/176128, acesso 07.10.19.

PARTIDO PIRATA DO BRASIL. O que é democracia direta. 23 jun. 2013. Disponível em http://partidopirata.org/o-que-e-democracia-direta/ Acesso em 22.08.19.

PAULA, Daniel Giotti de. Uma leitura crítica entre ativismo e judicialização da política. In FELLET, André Luiz Fernandes; PAULA, Daniel Giotti de; NOVELINO, Marcelo (org.). As novas faces do Ativismo Judicial. Salvador: Jus Podivm, 2011.

PAULA, Edylcéa Tavares Nogueira de. Do controle de constitucionalidade das leis. Sistemas de controle. Revista de informação legislativa, v. 19, n. 73, p. 95-100, jan./mar. 1982. Disponível em http://www2.senado.leg.br/bdsf/handle/id/181371, acesso 07.10.19.

PAULO, Vicente. ALEXANDRINO, Marcelo. Controle de Constitucionalidadel Vicente Paulo e Marcelo Alexandrino. - 1. Ed. - Rio de Janeiro, RJ: Impetus, 2004.

POGREBINSCHI, Thamy. Judicialização ou representação: política, direito e democracia no Brasil, Rio de Janeiro: Elsevier, 2011.

RAMOS, Elival da Silva. Ativismo Judicial: Parâmetros Dogmáticos - São Paulo: Saraiva, 2010.

RAWLS, John. O liberalismo político. ed. ampl. Álvaro de Vita (Trad.). São Paulo: WMF Martins Fontes, 2011.

RIBEIRO, Patrícia Carvalho. Judicialização da Política - Estudos de casos, 2008. Disponível em http://bd.camara.gov.br/bd/handle/bdcamara/5828. Acesso 09.10.19

SANSON, Alexandre. Dos grupos de pressão na democracia representativa: os limites jurídicos. 2013. Tese (Doutorado em Direito do Estado) - Faculdade de Direito, University of São Paulo, São Paulo, 2013. doi:10.11606/T.2.2013.tde-28072014133210. Acesso em: 2020-01-23.

SARMENTO, Daniel. 21 Anos de Constituição de 1988: a Assembléia Constituinte de 1987/1988 e a experiência constitucional brasileira. Revista de Direito Público, n.30, p.7-41, nov/dez 2009. 
STRECK, L. L. Entre o ativismo e a judicialização da política: a difícil concretização do direito fundamental a uma decisão judicial constitucionalmente adequada. Espaço Jurídico Journal of Law [EJJL], v. 17, n. 3, p. 721-732, 20 dez. 2016.

TEMER, Michel. Democracia e Cidadania. Malheiros, $1^{\text {a }}$ ed. São Paulo, 2006.

. Por uma democracia eficiente. Fundação Ulysses Guimarães. 2013. Disponível em https://www.fundacaoulysses.org.br/wp-content/uploads/imgpdf/1397141380-por-uma-democracia-eficiente-michel-temer.pdf Acesso em 14.10.19

VICTOR, Sérgio Antônio Ferreira. Diálogo institucional e Controle de Constitucionalidade: Debate entre o STF e o Congresso Nacional - São Paulo: Saraiva, 2015. - (Série IDP).

VIEIRA, Iacyr de Aguilar. O controle de constitucionalidade das leis e os diferentes sistemas. Revista de informação legislativa, v. 36, n. 141, p. 39-62, jan./mar. 1999. Disponível em: http://www2.senado.leg.br/bdsf/handle/id/448.

VIEIRA, Oscar Vilhena. Supremocracia. Revista Direito GV, [S.1.], v. 4, n. 2, p. 441463, jul. 2008. ISSN 2317-6172. Disponível em: <http://bibliotecadigital.fgv.br/ojs/index.php/revdireitogv/article/view/35159/33964>. Acesso em: 18 Set. 2019.

\section{SITES}

https://www.sunoresearch.com.br/artigos/welfare/ Acesso em 09.08.19

https://economia.uol.com.br/empregos-e-carreiras/noticias/redacao/2019/05/16/ desemprego-no-pais-pnad-ibge.htm

http://partidopirata.org/o-que-e-democracia-direta/ Acesso em 22.08.19

30 anos da Constituição, disponível em https://www.camara.leg.br/internet/agencia/infograficoshtml5/constituinte/index.html?u tm_source=WhatVDigital\&utm_medium $=$ banner\&utm_content=Tecnologia\&utm_cam paign=noticiasutm_source $=$ WhatVDigital\&utm_medium=banner\&utm_content=Tecnol ogia\&utm_campaign=noticias. Acesso em 10.10.19.

https://temas.folha.uol.com.br/desigualdade-global/brasil/super-ricos-no-brasil-lideramconcentracao-de-renda-global.shtml

Democracia No Brasil Disponível em https://www.youtube.com/channel/UCN68rShHGOW-cjJ7_oY0AQ/featured Acesso em 10.11.19. 